\title{
CAMILA SILANO
}

Fontes nitrogenadas e teor de proteína bruta em dietas com cana de açúcar para vacas em lactação: balanço de nitrogênio e análise econômica

Pirassununga

2014 
Fontes nitrogenadas e teor de proteína bruta em dietas com cana de açúcar para vacas em lactação: balanço de nitrogênio e análise econômica

Dissertação apresentada ao Programa de Pós-Graduação em Nutrição e Produção Animal da Faculdade de Medicina Veterinária e Zootecnia da Universidade de São Paulo para obtenção do título de Mestre em Ciências

\section{Departamento:}

Nutrição e Produção Animal

Área de concentração:

Nutrição e Produção Animal

Orientador:

Prof. Dr. Marcos Veiga dos Santos

De acordo: Marcos Vuiga dos foutos

Orientador

Pirassununga

2014

Obs: A versão original se encontra disponível na Biblioteca da FMVZ/USP 
Autorizo a reprodução parcial ou total desta obra, para fins acadêmicos, desde que citada a fonte.

DADOS INTERNACIONAIS DE CATALOGAÇÃO-NA-PUBLICAÇÃO

(Biblioteca Virginie Buff D’Ápice da Faculdade de Medicina Veterinária e Zootecnia da Universidade de São Paulo)

Silano, Camila

Fontes nitrogenadas e teor de proteína bruta em dietas com cana de açúcar para vacas em lactação: balanço de nitrogênio e análise econômica / Camila Silano. -- 2014.

88 f. : il.

Dissertação (Mestrado) - Universidade de São Paulo. Faculdade de Medicina Veterinária e Zootecnia. Departamento de Nutrição e Produção Animal, Pirassununga, 2014.

Programa de Pós-Graduação: Nutrição e Produção Animal.

Área de concentração: Nutrição e Produção Animal.

Orientador: Prof. Dr. Marcos Veiga dos Santos.

1. Fontes proteicas. 2. Vacas leiteiras. 3. Metabolismo proteico. 4. Custo de alimentação. 5. Margem bruta. I. Título. 


\section{CERTIFICADO}

Certificamos que o Projeto intitulado "Fontes protéicas em dietas à base de canade-açúcar para vacas leiteiras", protocolado sob o n 1634/2009, utilizando 12 (doze) bovinos, sob a responsabilidade do Prof. Dr. Marcos Veiga dos Santos, está de acordo com os princípios éticos de experimentação animal da Comissão de Bioética da Faculdade de Medicina Veterinária e Zootecnia da Universidade de São Paulo e foi aprovado em reunião de 18 de março de 2009.

We certify that the Research "Protein sources in diets based on sugar cane for dairy cows", protocol number 1634/2009, utilizing 12 (twelve) bovines, under the responsibility Prof. Dr. Marcos Veiga dos Santos, agree with Ethical Principles in Animal Research adopted by Bioethic Commission of the School of Veterinary Medicine and Animal Science of University of São Paulo and was approved in the meeting of day $03 / 18 / 09$.

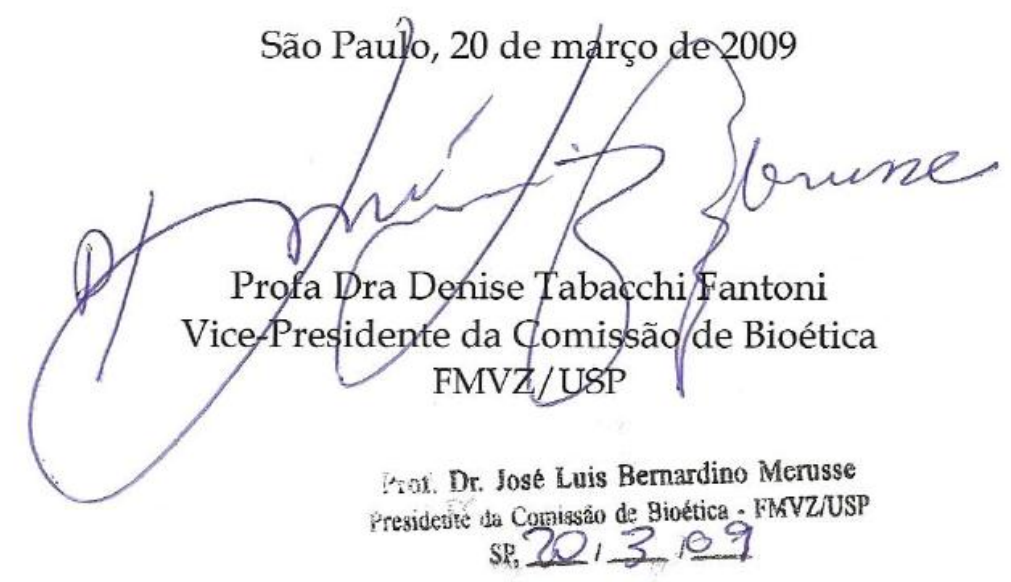




\section{FOLHA DE AVALIAÇÃO}

Nome: Silano, Camila

Título: Fontes nitrogenadas e teor de proteína bruta em dietas com cana de açúcar para vacas em lactação: balanço de nitrogênio e análise econômica

Dissertação apresentada ao Programa de Pós-Graduação em Nutrição e Produção Animal da Faculdade de Medicina Veterinária e Zootecnia da Universidade de São Paulo para obtenção do título de Mestre em Ciências

Data:

\section{Banca Examinadora}

Prof. Dr. :

Instituição:

Julgamento:

Prof. Dr.:

Instituição:

Julgamento:

Prof. Dr.:

Instituição:

Julgamento: 
Aos meus pais, pela companhia ao caminho percorrido até aqui e por me darem força e coragem para continuar caminhando... Ao meu sobrinho, que só está começando a vida, que um dia o inspire... À minha avó, por ter me acompanhado e torcer por mim... 


\section{Agradecimentos}

Agradeço a todas as pessoas que passaram na minha vida em algum momento, que me fizeram me tornar a pessoa que sou hoje e as escolhas que me trouxeram até aqui;

Aos meus pais, Lucy e Wanderley, que muitas vezes não só me apoiaram, mas também me seguraram firme em minhas escolhas. A todo amor, companheirismo, cumplicidade, amizade, conselhos... São sem dúvida o melhor de mim;

À minha avó, Dirce, que por muito tempo me teve como filha, todo o suporte e cuidado comigo. Tudo o que fiz e sou é também por ter a presença dela na minha vida.

À toda a minha família que muitas vezes compreenderam minha ausência, e mesmo de longe faziam parte dessa jornada.

Ao meu sobrinho, Romeo, que me esperava nos finais de semana com um abraço apertado que me faziam esquecer os problemas e dificuldades do mestrado.

Ao meu namorado, Diogo. Foi o melhor acontecimento que esse mestrado me proporcionou. Obrigada por me mostrar outros caminhos e me dar outras perspectivas. Obrigada pelo cuidado, atenção, amor e carinho que me dá incansavelmente.

Ao Prof. Dr. Marcos Veiga dos Santos por me aceitar como aluna e pela confiança.

Ao Prof. Dr. Augusto Hauber Gameiro, por toda a ajuda, orientação e motivação para a realização de parte deste trabalho.

À minha companheira de mestrado, amiga e cúmplice de muitas horas, Marina Migliano. Obrigada pela "metade". Obrigada pela companhia. Obrigada pela amizade.

À amiga e companheira dessa jornada, Nara Ladeira de Carvalho. Sua amizade foi muito importante pra mim.

Aos meus companheiros do laboratório Qualileite, Cristina Simões Cortinhas, Susana Macedo, Juliana Barreiro, Marcos Arcari, Juliano, Aline Dibbern, Cristian, Tiago Tomazi e Zeca. Foram muitos momentos bons e muitos momentos de trabalho que passamos juntos. Fizeram tudo ser mais especial.

À Lú, por toda a ajuda nas análises, dia após dia. Pelos conselhos, pelo ombro amigo e pela compreensão.

Ao estagiário William, que me auxiliou e fez companhia nos dias de análise no laboratório.

Desejo todo sucesso para você! 
A todos os amigos da pós-graduação do VNP. Porque mestrado não é só estudar, e conviver com vocês proporcionou momentos de muita diversão.

À Thyla, que me ajudou infinitamente nesse trabalho, me abriu as portas literalmente e me mostrou a luz no fim do túnel (rsrsrs), além da amizade que construímos nesse período.

Ao Maurício (Xibungo), pela ajuda com as estatísticas, dados, tabelas... Agradeço enormemente pela ajuda. Obrigada!

Aos funcionários do VNP Alessandra, João Paulo e Fábia, pela atenção e ajuda.

A todos os demais funcionários e colegas que de alguma forma contribuíram para o estudo e para o dia-a-dia no departamento. 
"Não importa como você bate e sim o quanto aguenta apanhar e continuar lutando, o quanto pode suportar e seguir em frente. É assim que se ganha."

Rocky Balboa

"Vencer é aproveitar as lições até o ponto de não mais voltar a cometer erros; é encontrar nos erros cometidos os pontos que nos fortalecem; é dominar com destreza a arte de saber perder".

Silvia Schmidt 


\section{RESUMO}

SILANO, C. Fontes nitrogenadas e teor de proteína bruta em dietas com cana de açúcar para vacas em lactação: balanço de nitrogênio e análise econômica. [Nitrogen sources and level of crude protein in diets with sugarcane for lactating dairy cows: nitrogen balance and economical evaluation]. 2014. 88 f. Dissertação (Mestrado em Ciências) - Faculdade de Medicina Veterinária e Zootecnia, Universidade de São Paulo, Pirassununga, 2014.

O estudo consistiu de dois experimentos com o objetivo de avaliar o efeito metabólico, custos e viabilidade econômica de dietas com diferentes fontes nitrogenadas e teores proteicos. No primeiro experimento avaliou-se o efeito de dois teores de proteína bruta (PB) (130 e 148g/kg de MS) e duas fontes nitrogenadas (farelo de algodão 38 e grão de soja cru integral) na dieta de vacas leiteiras com cana de açúcar como volumoso, sobre as frações nitrogenadas do leite, balanço de nitrogênio e perfil metabólico. Foram utilizadas 12 vacas da raça Holandesa com $155( \pm 65)$ dias em lactação, agrupadas em três quadrados latinos $4 \times 4$ contemporâneos, com período experimental de 21 dias, sendo 14 dias para adaptação às dietas e os sete últimos para a realização das coletas. As vacas foram alojadas em baias individuais e alimentadas ad libitum. As amostras de leite para análise do balanço nitrogenado e frações nitrogenadas foram coletadas no $15^{\circ}$ dia de cada período. O consumo e balanço de nitrogênio foram maiores para vacas alimentadas com dietas com 148 g PB/kg de MS. Por outro lado, vacas alimentadas com dietas contendo farelo de algodão apresentaram maior excreção de nitrogênio no leite do que vacas alimentadas com grão de soja cru integral. A relação entre caseína e proteína verdadeira no leite foi maior em vacas alimentadas com grão de soja cru integral. Houve interação entre fonte nitrogenada e teor de PB da dieta sobre as concentrações de nitrogênio ureico no leite (NUL) e nitrogênio não proteico (NNP). A concentração de NUL foi maior em vacas alimentadas com farelo de algodão e com maior teor de PB, em contrapartida houve menor excreção de NUL em vacas alimentadas com grão de soja com maior teor proteico. Não houve efeito das dietas sobre os teores de proteína do leite, nitrogênio não caseinoso (NNC), caseína e proteína do soro. Conclui-se que o uso de dietas com $130 \mathrm{~g}$ de $\mathrm{PB} / \mathrm{Kg}$ na MS não altera o balanço de nitrogênio e de composição do leite de vacas leiteiras em comparação com teores de $148 \mathrm{~g} / \mathrm{Kg}$ de PB na MS, e resultam em menor excreção de nitrogênio no ambiente. No segundo experimento foram calculados os custos e margens totais de dietas com cinco fontes nitrogenadas principais (ureia, farelo de soja, farelo de algodão, grão de soja cru integral e farelo de glúten de milho) e cinco teores proteicos 
(130, 145, 148, 157 e 160 g/kg de MS) com cana de açúcar como volumoso para vacas em lactação. Os dados foram provenientes de três estudos conduzidos com a finalidade de coleta de dados produtivos e respostas metabólicas. A análise econômica foi realizada com base nos preços históricos deflacionados (corrigidos do efeito da inflação) praticados durante o período 2002 a 2012, e no cálculo dos custos de alimentação, em função do consumo de alimento, da produção de leite e do teor de proteína bruta no leite. Dietas com cana de açúcar com teor proteico de 14,5\% com ureia como fonte nitrogenada principal apresentaram a maior margem bruta (diferença entre a receita da venda do leite e do custo da dieta) com valor médio anual de $\mathrm{R} \$ 1,85 . \mathrm{vaca}^{-1}$.dia ${ }^{-1}$. A dieta com 14,8\% de PB com grão de soja cru integral apresentou a menor margem bruta de $\mathrm{R} \$ 2,16 \cdot \mathrm{vaca}^{-1} \cdot \mathrm{dia}^{-1}$.

Palavras-chave: Fontes proteicas. Vacas leiteiras. Metabolismo proteico. Custo de alimentação. Margem bruta. 


\begin{abstract}
SILANO, C. Nitrogen sources and level of crude protein in diets with sugarcane for lactating dairy cows: nitrogen balance and economical evaluation. [Fontes nitrogenadas e teor de proteína bruta em dietas com cana de açúcar para vacas em lactação: balanço de nitrogênio e análise econômica]. 2014. 88 f. Dissertação (Mestrado em Ciências) - Faculdade de Medicina Veterinária e Zootecnia, Universidade de São Paulo, Pirassununga, 2014.
\end{abstract}

The study consisted of two experiments to evaluate the $\mathrm{N}$ balance and economical analysis of diets with different nitrogen sources and crude protein levels. On the first experiment it was evaluated the effect of two crude protein (CP) levels (130 e $148 \mathrm{~g} / \mathrm{kg} \mathrm{DM}$ ) and two nitrogen sources (cottonseed meal 38\% and whole raw soybean) in diets of dairy cows using sugar cane as forage on nitrogen in milk, nitrogen balance and metabolic parameters. Twelve Holstein cows with $155( \pm 65)$ days in lactation were distributed into three contemporary $4 \times 4$ Latin squares, with experimental period of 21 days, 14 days for diet adaptation and the remaining seven days for sampling. The cows were housed in individual pens and fed ad libitum. Milk samples for nitrogen balance and milk nitrogen fractions analysis were collected on the 15th day of each experimental period. Nitrogen intake and nitrogen balance were higher for the cows fed diets with $148 \mathrm{~g} \mathrm{CP} / \mathrm{kg}$ DM. However cows fed diets with cottonseed meal had higher nitrogen excretion in milk than cows fed diets with whole raw soybean. The casein: true milk protein ratio was higher in cows fed diets with whole raw soybean. There was interaction between the nitrogen source and the diet CP content on the milk urea nitrogen and non-protein nitrogen. Milk urea nitrogen was higher in cows fed diets with cottonseed meal and higher CP concentrations, however lower milk urea nitrogen was observed in cows fed diets with whole raw soybean and higher CP concentration. The concentration of crude protein, noncasein protein, casein and whey protein in milk did not differ between diets. In conclusion the use of low concentrations of protein $(130 \mathrm{~g} / \mathrm{Kg}$ in MS) does not affect the performance of dairy cows and provides lower excretion of nitrogen in the environment. On the second experiment, the costs and the gross margin were calculated for diets formulated with five nitrogen sources (urea, soybean meal, cottonseed meal, whole raw soybean and corn gluten meal) and five protein levels (130,145, 148, 157 e $160 \mathrm{~g} / \mathrm{kg} \mathrm{DM})$ using sugar cane as forage. Performance data were obtained from three experiments conducted previously. Economical analysis were performed based on historical prices adjusted for the effect of inflation during the period between 2002 and 2012 and based on the feed costs, cow intake, 
milk prodution and milk protein levels. The higher gross margin (difference between the income from milk sale and diet costs) were obtained for $145 \mathrm{~g} / \mathrm{kg}$ of CP in DM diets and urea as main nitrogen source, with mean of $\mathrm{R} \$ 1,85 . \mathrm{vaca}^{-1} \cdot \mathrm{dia}^{-1}$. The lower gross margin were observed in the $148 \mathrm{~g} / \mathrm{kg}$ of $\mathrm{CP}$ in DM diet and whole raw soybean as nitrogen source, with mean of R $2,16 \cdot$ vaca $^{-1} \cdot$ dia $^{-1}$.

Key words: Protein sources. Dairy cows. Protein metabolism. Feed Cost. Gross margin. 


\section{LISTA DE ABREVIAÇÕES E SIGLAS}

\begin{tabular}{|c|c|}
\hline AA & Aminoácidos \\
\hline AAE & Aminoácidos \\
\hline AANE & Aminoácidos não essenciais \\
\hline ATP & Adenosina trifosfato \\
\hline $\mathrm{BN}$ & Balanço de nitrogênio \\
\hline Cas:Pverd & Proporção entre caseína e proteína verdadeira \\
\hline $\mathrm{CD}$ & Coeficiente de digestibilidade \\
\hline CMS & Consumo de matéria seca \\
\hline CHOT & Carboidratos totais \\
\hline $\mathrm{CHO}$ & Carboidratos \\
\hline $\mathrm{CNF}$ & Carboidratos não fibrosos \\
\hline $\mathrm{COT}$ & Custo operacional total \\
\hline DEL & Dias em lactação \\
\hline ECC & Escore de condição corporal \\
\hline $\mathrm{EE}$ & Extrato etéreo \\
\hline EM & Energia metabolizável \\
\hline FDA & Fibra em detergente ácido \\
\hline FDAi & Fibra indigestível em detergente neutro \\
\hline FDN & Fibra em detergente neutro \\
\hline FS & Farelo de soja \\
\hline GS & Grão de soja \\
\hline MM & Matéria mineral \\
\hline $\mathrm{Mg}$ & Magnésio \\
\hline MN & Matéria natural \\
\hline MO & Matéria orgânica \\
\hline MS & Matéria seca \\
\hline $\mathrm{N}$ & Nitrogênio \\
\hline NDT & Nutrientes digestíveis totais \\
\hline NNC & Nitrogênio não caseinoso \\
\hline NNP & Nitrogênio não proteico \\
\hline NH3 & Amônia \\
\hline NH4 & Amônio \\
\hline N-NH3 & Nitrogênio amoniacal \\
\hline NUL & Nitrogênio ureico no leite \\
\hline PB & Proteína bruta \\
\hline NUS & Nitrogênio ureico no sangue \\
\hline $\mathrm{Ph}$ & Potencial hidrogeniônico \\
\hline PL & Produção de leite \\
\hline PMIC & Proteína microbiana \\
\hline PNDR & Proteína não degradável no rúmen \\
\hline PDR & Proteína degradável no rúmen \\
\hline
\end{tabular}


Ureia

V:C Proporção entre volumoso e concetrado 


\section{LISTA DE TABELAS}

Tabela 1 - Composição bromatológica dos ingredientes das dietas.

Tabela 2 - Composição bromatológica das dietas expressas em g/Kg de MS, de acordo com a fonte nitrogenada principal e dois teores de PB.

Tabela 3 - $\quad$ Efeito das dietas com grão de soja cru integral e farelo de algodão com teores de 130 e 148 $\mathrm{g} / \mathrm{kg}$ de $\mathrm{PB}$ na MS sobre frações proteicas do leite em vacas leiteiras.

Tabela 4 - Efeito das dietas com grão de soja cru integral e farelo de algodão com teores de 130 e 148 $\mathrm{g} / \mathrm{kg}$ de $\mathrm{PB}$ na MS sobre o balanço de nitrogênio em vacas leiteiras.

Tabela 5 - $\quad$ Efeito das dietas com grão de soja cru integral e farelo de algodão com teores de 130 e 148 $\mathrm{g} / \mathrm{kg}$ de PB na MS sobre os metabólitos plasmáticos.

Tabela 6 - Ingredientes utilizados na composição das dietas experimentais utilizadas no experimento $1 .$.

Tabela 7- Ingredientes utilizados na composição das dietas experimentais utilizadas no experimento 2.

Tabela 8 - Ingredientes utilizados na composição das dietas experimentais utilizadas no experimento 3.

Tabela 9 - Dados de consumo de ração, produção de leite e teor de proteína bruta média no leite de acordo com cada dieta experimental nos três experimentos estudados.

Tabela 10 - Custos das dietas por quilo, por vaca, por litro de leite e por porcentagem de proteína bruta no leite, margens médias e totais das dietas

Tabela 11 - Médias mensais e média anual das margens totais em função das dietas. 


\section{LISTA DE FIGURAS}

Figura 1 - $\quad$ Interação entre a fonte nitrogenada e o teor de proteína bruta da dieta sobre o NNP em vacas leiteiras.

Figura 2 - Interação entre a fonte nitrogenada e o teor de proteína bruta da dieta sobre o nitrogênio ureico no leite em vacas leiteiras.

Figura 3 - $\quad$ Interação entre a fonte nitrogenada e o teor de proteína bruta da dieta sobre a glicose sanguínea em vacas leiteiras....

Figura 4 - Interação entre a fonte nitrogenada e o teor de proteína bruta da dieta sobre o teor de colesterol total em vacas leiteiras.

Figura 5 - $\quad$ Interação entre a fonte nitrogenada e o teor de proteína bruta da dieta sobre o teor de uréia no soro em vacas leiteiras...

Figura 6 - Interação entre a fonte nitrogenada e o teor de proteína bruta da dieta sobre o teor de nitrogênio ureico no sangue em vacas leiteiras

Figura 7 - Curvas das margens totais mensais das dietas

Figura 8 - Gráfico da série histórica dos preços nominais da ureia ao longo do ano

Figura 9 - Série histórica dos preços nominais da cana de açúcar ao longo do ano

Figura 10 - $\quad$ Série histórica dos preços nominais do grão de soja cru integral ao longo do ano.

Figura 11 - Margens totais das dietas em função dos preços pagos por teor de PB no leite

Figura 12 - Curvas dos custos mensais das dietas por teor de proteína bruta no leite... 


\section{SUMÁRIO}

CAPÍTULO 1: REVISÃO DE LITERATURA

CAPítULO 2: Farelo de algodão e grão de soja cru integral em dietas com cana-deaçúcar para vacas leiteiras: frações nitrogenadas do leite, balanço de nitrogênio e perfil metabólico

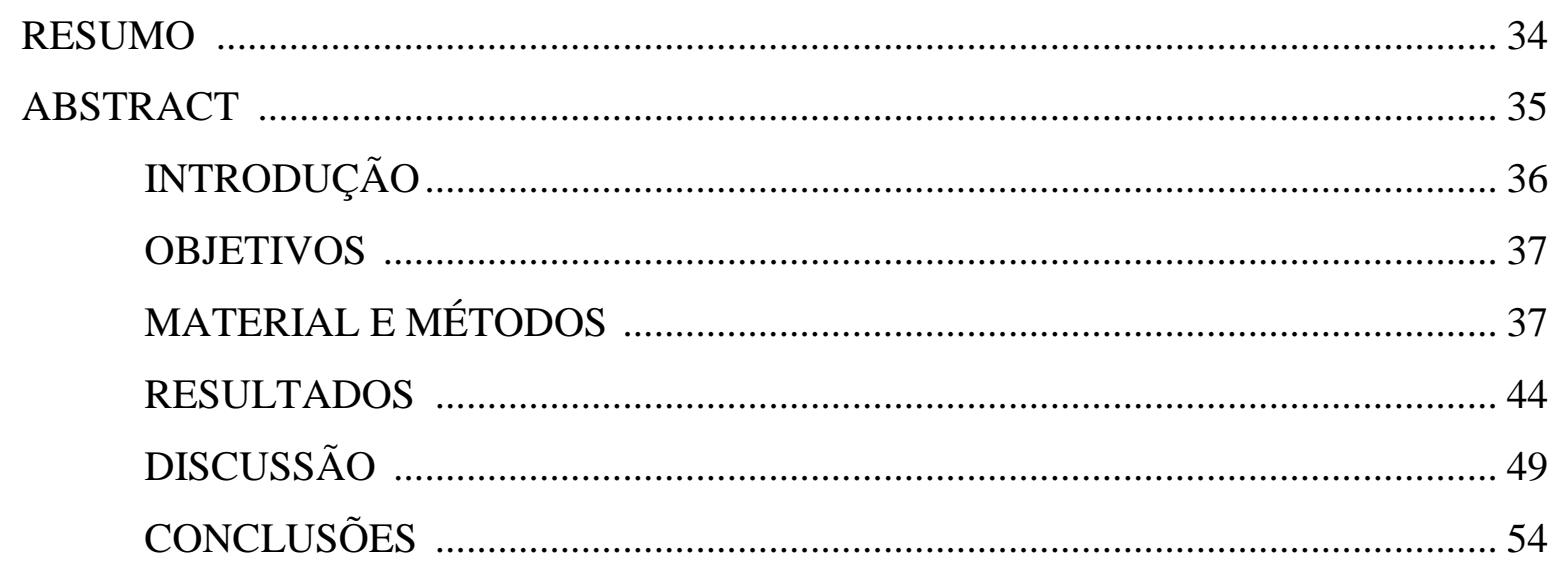

CAPíTULO 3: Fontes nitrogenadas e teor de proteína bruta em dietas com cana de açúcar para vacas em lactação: análise econômica

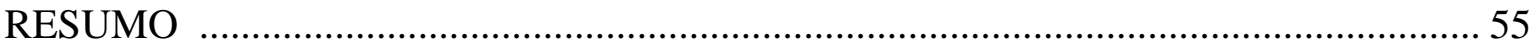

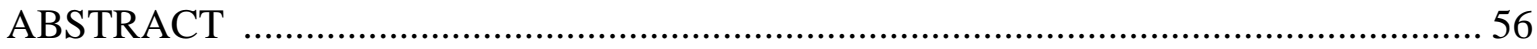

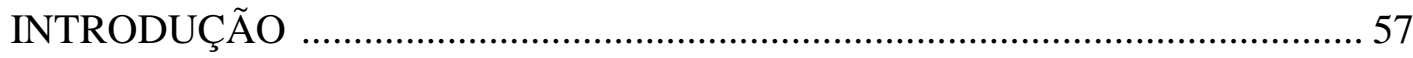

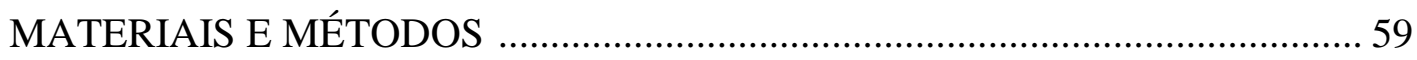

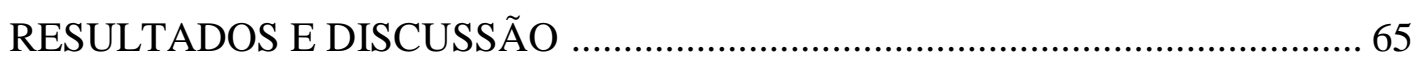

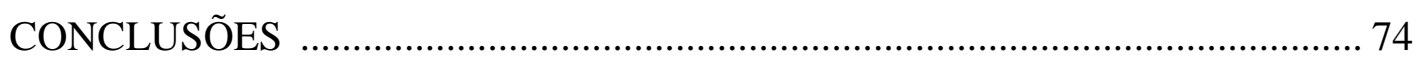

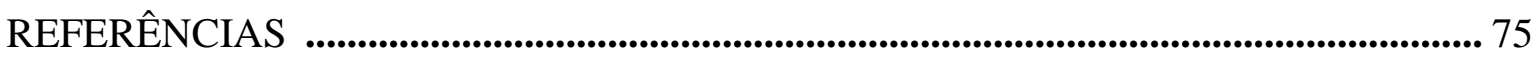




\section{CAPÍTULO 1: REVISÃO DE LITERATURA}

\section{Metabolismo proteico de vacas leiteiras}

Nos últimos 30 anos, os conceitos de nutrição proteica em ruminantes evoluíram consideravelmente. A partir de estudos sobre as exigências de $\mathrm{N}$ dos ruminantes, foram desenvolvidos os conceitos de exigências proteicas de manutenção e produção. A exigência proteica de manutenção provém do metabolismo endógeno urinário, fecal, de descamação de pele e pelos. Já a exigência de $\mathrm{N}$ para produção refere-se ao $\mathrm{N}$ necessário para a gestação e lactação. Atualmente, os conceitos de exigências proteicas são baseados em proteína degradável no rúmen (PDR) e proteína não degradável rúmen (PNDR) (NRC, 1985, 1989; INRA, 1988; AFRC, 1992; NRC, 2001), além das exigências de proteína metabolizável, e de compostos nitrogenados para a população microbiana ruminal.

O uso dos conceitos de exigências metabolizáveis possibilitou maior eficiência da produção de ruminantes pela redução de perdas de compostos nitrogenados justamente pela possibilidade da adequação de doses de proteína não degradável no rúmen e adequação da qualidade e quantidade da proteína fornecida a estes animais. Além disso, com a adequação do fornecimento e redução de excessos de nitrogênio pode ocorrer redução do impacto ambiental pela menor liberação de compostos nitrogenados para o ambiente (TAMMINGA, 1996).

Proteínas são macromoléculas compostas por aminoácidos unidos por ligações peptídicas, as quais são formadas por um grupo carboxila $(\mathrm{COOH})$ e um grupo amino $\left(\mathrm{NH}^{+}\right)$. Aminoácidos não essenciais são aqueles sintetizados pelo metabolismo endógeno a partir de metabólitos ou excessos de aminoácidos digeridos. No entanto, alguns aminoácidos essenciais, não são sintetizados pela microbiota ruminal ou sintetizados em pequenas quantidades, como Phe, Leu e Ile, os quais devem ser fornecidos aos animais pela dieta.

Alguns fatores podem afetar a eficiência de utilização dos aminoácidos pelo animal. A degradação da proteína no rúmen é afetada principalmente pelo $\mathrm{pH}$ ruminal e pelas espécies que compõe a microbiota. A atividade proteolítica das bactérias é menor quando há redução de pH e em dietas desbalanceadas, por exemplo com alto teor de fibra. $\mathrm{O}$ acúmulo de $\mathrm{N}$ observado no rúmen sugere que um dos fatores limitantes da degradação proteica é a capacidade de utilização do nitrogênio pelos microrganismos ruminais (BACH et al., 2005).

A proteína bruta contida nos alimentos é composta por uma fração degradável no rúmen 
(PDR) e outra não degradável no rúmen (PNDR). A PDR é composta de uma fração não proteica e uma fração nitrogenada derivada da proteína verdadeira. A proteína verdadeira, degradada no rúmen sofre ação das enzimas produzidas e secretadas pelas bactérias ruminais, peptidases, proteases e deaminases. Quando a proteína da dieta chega ao rúmen é adsorvida pelas bactérias e então sofre a ação das proteases. A taxa de degradação proteica varia de acordo com a atividade proteolítica da microbiota ruminal e com a estrutura das proteínas, que determinam a susceptibilidade e acessibilidade das ligações peptídicas à ação enzimática.

Os produtos da degradação das proteínas (peptídeos e aminoácidos) são utilizados pelas bactérias para síntese de proteína microbiana, a qual é a principal fonte de proteína metabolizável para ruminantes. Os peptídeos podem ser degradados por peptidases em aminoácidos para serem também incorporados à proteína microbiana ou deaminados em ácidos graxos voláteis, $\mathrm{CO}_{2}$ e amônia. A quantidade de energia disponível no rúmen é um dos fatores que afetam a utilização de aminoácidos e proteínas. Quando há energia suficiente para o metabolismo microbiano, os aminoácidos são utilizados para síntese de proteína microbiana, se o fator limitante for a disponibilidade de energia, os aminoácidos serão fontes de ácidos graxos voláteis e amônia (CLARK et al., 1992).

Além disso, se a capacidade de degradação proteica no rúmen exceder a capacidade de utilização pela microbiota ruminal, o excesso de amônia não utilizado pela microbiota é excretado para o ambiente ruminal, o que torna o $\mathrm{pH}$ ruminal elevado e favorece sua absorção pelo epitélio ruminal (TAMMINGA, 1979). No fígado, a amônia é metabolizada pelo do ciclo da ureia para ser excretada pela urina ou reciclada pela saliva e corrente sanguínea para retornar novamente ao rúmen (SANTOS, 2006). Peptídeos e aminoácidos em excesso fazem parte do fluxo da digesta para serem absorvidos no intestino. A degradação de proteínas pode ser alterada por modulação da proteólise e alterações na peptidólise e deaminação, por exemplo, pela a seleção de bactérias que favoreçam a peptidólise e reduzam a deaminação a amônia (CHEN; RUSSELL, 1989).

Parte da amônia produzida pelas bactérias é absorvida por protozoários. Como os os protozoários não são capazes de utilizar amônia como fonte de energia, as frações de proteínas insolúveis previamente captadas retornam ao rúmen na forma de proteínas solúveis para serem aproveitadas para o crescimento microbiano (ONODERA et al., 1977). Os protozoários representam cerca de $40 \%$ da microbiota ruminal (RUSSELL; RYCHLIK, 2001) e além de fazerem parte da reciclagem de amônia, são capazes degradar carboidratos fibrosos e não fibrosos (WITHERS; WILLIAMS, 1998) e de englobar grandes moléculas, proteínas, carboidratos e até mesmo bactérias, aumentando com a degradação de proteínas no rúmen 
(VAN SOEST, 1994). No entanto, os protozoários são responsáveis por apenas $11 \%$ do fluxo de proteína para o intestino delgado, pois a maior parte da população fica retida no rúmen (SHABI et al., 2000).

A solubilidade das proteínas determina a susceptibilidade da proteína às proteases e consequentemente a degradabilidade (BACH et al., 2005). A solubilidade é determinada pela estrutura das moléculas, por exemplo, a presença de ligações e pontes entre as cadeias proteicas (estruturas terciárias e quaternárias) tornam as proteínas menos solúveis e consequentemente menos degradáveis (SCHWINGEL; BATES, 1996). A taxa de passagem ruminal é inversamente proporcional à degradação proteica (ORSKOV; MCDONALD, 1979). Alto fluxo de passagem reduz o contato entre das proteínas e enzimas ruminais o que reduz a taxa de degradação ruminal.

As proteínas não degradáveis no rúmen são importantes como fonte de aminoácidos complementar à proteína degradável no rúmen, de forma a suprir as exigências de proteína metabolizável dos ruminantes (KALSCHEUR et al., 2006). No entanto, é necessário que essa fonte proteica seja de alto valor biológico, com perfil aminoacídico adequado para suprir adequadamente essas exigências. A quantificação dos teores de lisina e metionina, os dois aminoácidos limitantes para bovinos, é um dos métodos de avaliação da qualidade proteica da dieta (NRC, 2001).

O processo de digestão da PDR no rúmen tem início no abomaso e continua pelo duodeno e jejuno. No abomaso as proteínas sofrem ação prolongada da pepsina, já no duodeno e jejuno as enzimas pancreáticas, tripsina quimotripsina e carboxipeptidases apresentam máxima atividade e finalizam o processo de digestão proteica com a formação de aminoácidos livres e pequenos peptídeos como produto. Esses produtos são então absorvidos através do epitélio intestinal, e posteriormente chegam aos tecidos, incluindo a glândula mamária, onde são incorporados na síntese da fração proteica do leite.

\section{Perfil Metabólico}

O perfil metabólico sanguíneo pode ser utilizado como indicador da saúde da vaca leiteira e desequilíbrios metabólicos, o que pode possibilitar o balanceamento da dieta e a intensificação da produtividade (CALIXTO et al., 2010). Além disso, podem ser utilizados para avaliar o processo de adaptação do metabolismo a novas dietas ou alterações fisiológicas. 
As concentrações sanguíneas de ureia, hemoglobulinas, globulinas, albuminas e proteínas totais podem ser usadas para avaliar o metabolismo proteico (DIRKSEN; BREITNER, 1993) e o balanço nitrogenado da dieta. Porém, essas análises são muito correlacionadas com o período de avaliação, pois podem ocorrer variações após a alimentação.

A concentração de ureia plasmática é um indicador sensível e imediato da ingestão da proteína (GONZÁLEZ, 2002), pois é alterada pela taxa de detoxificação da amônia no fígado, já que a síntese de ureia ocorre por meio do ciclo da ureia com amônia como precursor. Os teores de ureia plasmática são altamente dependentes da conversão e amônia pelo fígado para ser excretada, devido a sua toxicidade (LENG; NOLAN, 1984). Os teores de ureia plasmática em vacas leiteiras descritos na maioria dos estudos variam de 15 a $40 \mathrm{mg} / \mathrm{dL}$, e refletem um metabolismo hepático e proteico adequados (VILELA; TEIXEIRA; REIS, 2005).

O excesso de amônia não aproveitado pela microbiota ruminal é absorvido pelo epitélio ruminal para a corrente sanguínea. Portanto, altas concentrações de nitrogênio sanguíneo indicam ineficiência no uso da proteína dietética ou excesso de nitrogênio na dieta (BRODERICK; CLAYTON, 1997). Por outro lado, concentrações de nitrogênio no sangue abaixo de $11 \mathrm{mg} / \mathrm{dL}$ podem indicar quantidade insuficiente de PDR na dieta (BRODERICK et al., 1993).

As concentrações de glicose, colesterol (HDL, LDL e VLDL) e beta-hidroxibutirato podem ser determinadas para a avaliação do metabolismo energético (DIRKSEN; BREITNER, 1993). A variação de glicemia para vacas é de 40 a 60 mg/dL (FRASER, 1991). Em ruminantes a glicose é originada no fígado a partir de glicerol, lactato, proteínas e propionato (REECE, 1996). Dependendo da fase produtiva em que as vacas se encontram, a glândula mamária demanda elevadas quantidades extras de glicose para a síntese de lactose do leite.

As lipoproteínas HDL, LDL e VLDL são carreadores de colesterol na corrente sanguínea. Estão na forma esterificada com ácidos graxos e representam quase $30 \%$ do total de lipídeos plasmáticos. O aumento de teores de colesterol pode indicar dietas ricas em gordura, podendo também estar relacionado a vacas em início de lactação. Baixo teor de colesterol pode ser indicativo de dietas com deficiências energéticas ou ser devido a alterações fisiológicas de vacas em período pré-parto (GONZÁLEZ, 2003).

Pires et al. (2010), ao estudar dietas com cana-de-açúcar na proporção volumoso: concentrado de 40:60 e diferentes processamentos ou fonte de amido não encontraram alterações nas concentrações de glicose e ureia plasmáticas. Martinez (2008), ao avaliar dietas com caroço de algodão e cana de açúcar, não observaram efeitos das dietas sobre as concentrações de glicose plasmática. Entretanto, observaram aumento na concentração de 
nitrogênio ureico no plasma com a inclusão de 34\% de caroço de algodão na ração.

O perfil metabólico pode ser utilizado como indicador proteico devido às respostas imediatas do metabolismo proteico. No entanto, aspectos de manejo, saúde e estado fisiológico dos animais pode determinar alterações provenientes de outras rotas metabólicas, como energética. Quando estes indicadores encontram-se fora intervalo de referência deve-se analisar a possibilidade de correções para evitar reduções na produção, fertilidade e rentabilidade (CONTRERAS, 2000).

\section{Balanço de nitrogênio}

A eficiência do metabolismo proteico pode ser avaliada por meio de indicadores exógenos como a excreção de compostos nitrogenados na urina, fezes e leite. A amônia produzida em excesso, ou seja, não aproveitada pela microbiota ruminal, é absorvida para a corrente sanguínea (RUSSEL, 1992). Isso ocorre quando a taxa de degradação proteica excede a fermentação de carboidratos no rúmen, geralmente quando há alta concentração de PDR na dieta (BRODERICK, 2003). Essa situação acarreta em aumento do teor de nitrogênio ureico no sangue (BUTLER et al., 1996), indicando a ineficiência na utilização do nitrogênio proveniente da PDR da dieta.

A retenção de nitrogênio em relação ao nitrogênio absorvido reflete a utilização do nitrogênio na síntese proteica. A eficiência da absorção microbiana de nitrogênio depende fundamentalmente da composição do composto nitrogenado que chega aos tecidos, vindos da absorção intestinal. O teor de nitrogênio ureico no leite (NUL) pode ser correlacionado com a quantidade de amônia produzida no rúmen e a circulante (GUSTAFFSSON; PALMQUIST, 1993). Por isso o NUL é considerado um bom indicador do balanço nitrogenado da dieta (BRODERICK; CLAYTON, 1997). O nitrogênio excretado nas fezes e urina é proveniente da circulação sanguínea e, portanto, é outra forma de correlação com o teor de nitrogênio sanguíneo. (BRODERICK, 2003).

O fluxo de nitrogênio (N) microbiano para o duodeno pode ser estimado a partir da excreção urinária dos derivados de purina (principalmente alantoína e ácido úrico), sendo a quantidade de ácido nucléico microbiano e a síntese microbiana ruminal correlacionadas à excreção urinária dos derivados de purina (MOSCARDINI et al., 1998). A utilização dos 
derivados de purina urinários para estimativa de alterações na síntese microbiana ruminal foi observada com a mesma eficiência do método baseado na medição do fluxo duodenal pela técnica de indicadores (GONZÁLEZ-RONQUILLO et al., 2003). Uma única amostra spot de urina de cada vaca em cada período experimental, utilizada para quantificação do volume urinário com base na excreção de creatinina, produziu aproximadamente a mesma estimativa da excreção urinária de derivados de purina e, consequentemente, da produção de $\mathrm{N}$ microbiano, quando comparada à coleta total de urina (VALADARES et al., 1999b).

A alta concentração de PB na dieta, em especial a porcentagem de PDR está positivamente associada com a maior degradação de proteína e concentração de amônia ruminal (BRODERICK, 2003; HRISTOV et al., 2004). O excesso de PDR aumenta a difusão de amônia pela parede do rúmen para o sangue, o que causa elevação do teor do nitrogênio ureico no plasma (NUP) (BUTLER et al., 1996), que é indicativo da ineficiência na utilização do nitrogênio dietético (NOUSIAINEN et al., 2004) para produção de leite.

O excesso de nitrogênio sanguíneo é convertido em ureia no fígado, sendo a principal forma de excreção de nitrogênio em mamíferos. A medição rotineira do NUP é difícil e inviável em sistemas de produção, todavia, a concentração de ureia equilibra-se rapidamente nos fluidos corporais, incluindo o leite (NUL), o que resulta em alta correlação com o NUP (GUSTAFSSON; PALMQUIST, 1993) e por isso o NUL é considerado um bom indicador do balanço nitrogenado da dieta (BRODERICK; CLAYTON, 1997). O excesso de nitrogênio sanguíneo também é excretado na urina e nas fezes (MUCK, 1982; BRODERICK, 2003).

Uma vaca com produção de $8.000 \mathrm{~kg}$ de leite/lactação excreta aproximadamente 20 toneladas de fezes e aproximadamente $120 \mathrm{~kg}$ de N para o ambiente (VAN HORN et al., 1996). Aproximadamente 25 a 35\% do N ingerido são excretados no leite, e 65 a75\% são excretados via urina e fezes, o que resulta em alta correlação entre a ingestão de nitrogênio e sua excreção nas fezes (CHASE, 1994; YAN ET al., 2006). O N excretado é rapidamente hidrolisado em $\mathrm{NH}_{3}$ e perdido por volatilização para o ambiente (MUCK, 1982; VANHORN et al., 1994).

$\mathrm{O}$ excesso de $\mathrm{N}$ pode afetar o desempenho reprodutivo, aumentar a demanda energética em 13,3Kcal de energia digestível por grama de $\mathrm{N}$ a ser excretado na forma de ureia, além da contaminação ambiental com N (BRODERICK; CLAYTON, 1997). A concentração de NUL é de fácil determinação e pode ser usada para monitorar a nutrição proteica de vacas leiteiras (SCHEPERS; MEIJER, 1998). 


\section{Cana de açúcar na alimentação de vacas leiteiras}

Entre os diversos fatores que interferem na produção leiteira, destaca-se a formulação da dieta balanceada, o manejo e fornecimento adequado para permitir a ingestão de todo o conteúdo de maneira homogênea para garantir que os nutrientes formulados sejam ingeridos. Em estudo para avaliar sistemas intensivos de produção, Nussio et al. (2005), descreveram as silagens de sorgo e de milho como as fontes de volumoso mais utilizadas no Brasil. Porém, o uso desses alimentos como fonte de volumoso pode ter limitações pelo aporte de recursos técnicos e financeiros em determinados períodos do ano que podem ser mais críticos para a produção desta forragem. Por isso, o grande desafio dos produtores de leite tem sido encontrar sistemas alternativos de produção de forragens ou utilização de outras fontes alternativas nesses períodos.

A cana de açúcar é uma fonte de volumoso que possui grande potencial como forrageira tropical devido suas características produtivas. A cana de açúcar pode ser facilmente cultivada, pois é de fácil implantação e manutenção (TORRES; REZENDE, 1996). A produtividade média da planta inteira de cana de açúcar (colmo, folhas secas e ponteiros) é de cerca de 100 toneladas de matéria natural $(\mathrm{MN})$ por hectare por ano. Com o manejo adequado de variedades e de técnicas de calagem e adubação, é possível obter produtividades superiores a 100 toneladas de MN/ha/ano (OLIVEIRA et al., 2001). Em média, a cana de açúcar apresenta teores de MS entre 24 e 34\% no momento da colheita. Entretanto, esses valores dependem do estágio de maturação, variedade e outras características inerentes à planta. O teor de MS da cana-de-açúcar aumenta à medida que avança o estádio fisiológico da planta, principalmente pelo acúmulo de sacarose (KUNG; STANLEY, 1982).

No entanto, a cana de açúcar apresenta algumas limitações nutricionais quando utilizada como única fonte de volumoso para vacas de média e alta produção. Essas limitações ocorrem principalmente devido à baixa digestibilidade da fibra, que acarreta maior preenchimento ruminal e menor consumo de matéria seca (MAGALHÃES et al., 2004). Costa et al. (2005) compararam dietas com cana de açúcar e silagem de milho com a mesma relação volumoso:concentrado (60:40) e relataram consumo 22,51\% superior para a dieta contendo silagem de milho. Magalhães et al. (2004) e Sousa (2003) observaram aumento de $15 \%$ no consumo em dietas à base de silagem de milho quando comparadas com aquelas baseadas em cana de açúcar. Magalhães et al. (2006), avaliaram a substituição de silagem de milho por cana de açúcar em níveis de 0; 33,3; 66,6 e 100\% em dietas para vacas da raça Holandesa em 
lactação, e observaram que os consumos médios de todos os nutrientes diminuíram à medida que a silagem de milho foi substituída pela cana de açúcar. Sendo assim, o uso da cana de açúcar tem sido associado negativamente ao consumo de matéria seca não só pela fração da fibra que é indigestível, mas também pela baixa taxa de digestão da fibra digestível, que apresentam elevado efeito de preenchimento ruminal.

Esta redução de CMS acarreta também menor consumo de matéria mineral (MM), extrato etéreo (EE), nutrientes digestíveis totais (NDT), FDN e FDA, além da cana de açúcar já apresentar menor teor desses nutrientes. Magalhães et al. (2006) demonstrou redução linear no coeficiente de digestibilidade do EE e FDN com o aumento da inclusão de cana de açúcar nas dietas para vacas leiteiras. Costa et al. (2005) avaliaram o consumo e digestibilidade de três dietas com cana de açúcar como volumoso único nas proporções 60:40, 50:50 e 40:60 de inclusão e uma dieta com silagem de milho (60:40). O consumo de MS, MO, PB, FDN, e CHO foi menor em vacas alimentadas para inclusão de $60 \%$ de cana de açúcar, intermediário no nível de $50 \%$ e maior no de $40 \%$. O consumo de nutrientes em vacas alimentadas com dieta com $40 \%$ de cana de açúcar foi semelhante ao obtido com a dieta à base de $60 \%$ de silagem de milho. Não foram verificadas diferenças na digestibilidade aparente da matéria seca, matéria orgânica e carboidratos entre as dietas. $\mathrm{O}$ coeficiente de digestibilidade da PB foi maior na dieta com silagem de milho e o de FDN semelhante nas dietas à base de cana de açúcar.

De maneira geral, o valor nutricional das gramíneas diminui com o avançar do estágio de maturação, porém o valor nutritivo da cana de açúcar e a digestibilidade da matéria seca, aumenta com a maturidade. Com o avançar da idade da cana de açúcar ocorrem decréscimos de teores de fibra (FDN), de proteína bruta (PB) e aumento nos teores de matéria seca (MS) e carboidratos não fibrosos (CNF), sendo este aumento de CNF resultado do acúmulo de sacarose. Essas características resultam em importante vantagem para a alimentação animal, particularmente no período seco e frio do ano, época em que seu valor energético é máximo, enquanto outras gramíneas forrageiras atingem seus limites mínimos (GOODING, 1982).

Outra importante limitação da cana de açúcar é o baixo teor de PB (2 a 4\% da MS) que não atendem as exigências de vacas, independentemente da categoria animal. Por isso é necessária suplementação proteica com compostos nitrogenados degradáveis no rúmen, proteína não degradável no rúmen, precursores glicogênicos para a obtenção de melhores índices de desempenhos (PEREIRA et al., 2006).

Em relação à fermentação ruminal, dietas com cana de açúcar caracterizam-se por manter o pH elevado e estável devido à alta capacidade desse alimento em estimular a salivação em razão do alto teor de fibra (LENG; PRESTON, 1976). A alta concentração de 
protozoários do rúmen presente em dietas a base de cana de açúcar ajuda na estabilização do pH elevado devido à rápida assimilação dos carboidratos solúveis por esses microrganismos.

A taxa de passagem de um alimento é determinada pelo consumo de MS e pela qualidade da fibra e digestibilidade dos nutrientes. A somatória dos fatores de consumo e digestibilidade em dietas com cana de açúcar resulta em redução da taxa de passagem ruminal e proporcional aumento do tempo de retenção ruminal. Comparada à silagem de milho a cana de açúcar possui alto teor de FDNi, que promove menor consumo de MS pela maior capacidade de preenchimento ruminal. (FERNANDES et al., 2003b).

Juntamente com a quantidade de MS consumida, a taxa na qual o alimento se move ao longo do trato gastrintestinal e a taxa de fermentação são os principais fatores que determinam o quanto os nutrientes serão digeridos, absorvidos e utilizados pelo animal (COLUCCI et al., 1982). Alteração em qualquer um desses três fatores geralmente muda os outros dois.

Costa et al. (2005) avaliaram o desempenho produtivo de vacas leiteiras com média de produção de $22 \mathrm{~kg} /$ dia, alimentadas com diferentes proporções de cana de açúcar e concentrado ou silagem de milho na dieta. Foi observada que a produção de leite de vacas alimentadas à base de dieta com $60 \%$ de cana de açúcar foi menor $(\mathrm{p}<0,05)$ do que quando utilizada em menor proporção, com apenas $40 \%$ de cana de açúcar. Os estudos descreveram que a menor produção de leite das vacas com as dietas com maior participação de cana de açúcar pode ser explicada pelo menor consumo de MS, o que resultou em menor consumo de nutrientes.

\section{Grão de soja na alimentação de vacas leiteiras}

O Brasil é o segundo maior produtor mundial de soja, com produção de 81,45 milhões de toneladas produzidas na safra 2012/2013 em 27,72 milhões de hectares, que corresponde a uma produtividade de $2.938 \mathrm{~kg} / \mathrm{ha}$ (CONAB - Setembro, 2013). Assim, dentre as diversas fontes proteicas disponíveis para uso em dietas de vacas leiteiras o grão de soja se destaca pela disponibilidade além do elevado conteúdo de nutrientes.

O grão de soja cru apresenta nutrientes de alto valor biológico, com teor médio de proteína bruta de 39,3\%, 19,2\% de extrato etéreo e 95\% de NDT, fibra de alta digestibilidade e alta efetividade comparada a outros alimentos concentrados (NRC, 2001). No entanto, o grão de soja cru integral na alimentação de ruminantes tem sido utilizado com ressalvas devido à 
presença de fatores antinutricionais importantes e substâncias tóxicas (fatores alergênicos e anticoagulantes). Porém, a maior parte das substâncias tóxicas não apresentam limitações em dietas para ruminantes, pois são inativadas ou metabolizadas durante o processo de digestão ruminal. A maior limitação são os fatores antinutricionais, que podem apresentar efeito sobre enzimas relacionadas ao processo de digestão de proteínas com a redução da digestibilidade da dieta e aumento da excreção do nitrogênio não utilizado (McDONALD et al., 2002; LANA, 2004).

Os fatores antinutricionais do grão se soja interferem no aproveitamento dos nutrientes ingeridos, principalmente proteínas, pela inativação de proteases. A presença de inibidores de tripsinas resulta em menor ganho de peso, menor consumo de alimentos e menor eficiência proteica. Os inibidores de proteases da soja são classificados em duas principais categorias: os inibidores tipo Bowman-Birk são de alto peso molecular com 71 aminoácidos ligados por sete pontes dissulfeto, que formam uma molécula compacta e relativamente termoestável com sítios de ligações independentes para a tripsina e quimotripsina (WEDER, 1985). Já os inibidores tipo Kunitz são os de baixo a médio peso molecular, com 181 aminoácidos com duas ligações dissulfeto, e especificidade primária à tripsina (LIENER, 1994). O grão de soja apresenta no máximo duas formas dos inibidores Kunitz e de 5 a 12 formas de inibidores do tipo BowmanBirk (TAN WILSON; WILSON, 1986).

O grão de soja cru é naturalmente uma fonte de proteína degradável no rúmen, ou seja, fonte de nitrogênio para síntese de proteína microbiana. Para vacas leiteiras de alta produção (>40 kg/dia), a situação adequada em termos nutricionais, é fornecer maior quantidade de PNDR, sendo recomendado que 35-45\% da PB da dieta seja oriunda da PNDR (NRC, 2001). No entanto, para sistemas de produção de leite, com dietas a base de cana-de-açúcar como volumoso, essa proporção de PNDR na dieta é reduzida em função da menor produtividade das vacas.

Mielke e Shingoethe (1981) avaliaram dietas com farelo de soja, grão de soja cru e grão de soja tostado na alimentação de vacas primíparas em início de lactação. Foi utilizada silagem de milho como maior parte do volumoso, associada a feno de alfafa. A quantidade de grão de soja consumida foi de 2,19 e 2,14 Kg/vaca/dia. Não foi observado efeito entre as dietas utilizadas no consumo de matéria seca e de proteína bruta, e na produção de leite e teor de gordura. Faldet e Satter (1991) avaliaram vacas em início de lactação, com média de produção de leite de 35,0 Kg/dia com o objetivo de comparar o desempenho produtivo de vacas alimentadas com grão de soja tostado em relação ao farelo de soja e ao grão de soja moído grosseiramente, com silagem de alfafa como fonte de volumoso. Foi observado aumento da 
produção de leite e redução dos teores de gordura e proteína do leite quando comparado o desempenho de vacas alimentadas com grão de soja tostado com a dieta com farelo de soja ou grão de soja cru moído. No entanto, não foi encontrada diferença sobre a produção e composição do leite e consumo.

Vacas Holandesas com produção de $28 \mathrm{~kg}$ de leite/dia em início de lactação foram alimentadas com 0, 12 e $24 \%$ da matéria seca total de grão de soja crua triturada grosseiramente, sendo equivalente no concentrado a $0,20 \%$ e $40 \%$ de grão de soja. $\mathrm{O}$ volumoso utilizado foi a silagem de milho com relação 60:40 (DERESZ; FERNANDES; MATOS, 1996). Segundo os autores, não foram observados efeitos da utilização de até $40 \%$ do concentrado de grão de soja sobre a produção e composição do leite e o consumo de matéria seca e nutrientes.

Em estudos com vacas após o pico de lactação, com produção de $26 \mathrm{~kg}$ de leite/dia alimentadas com silagem de milho como volumoso basal e concentrado na relação 50:50 com 0,15, 30 e 45\% de grão de soja moído, O consumo de grão de soja foi de 1,34, 2,73 e 3,65 $\mathrm{kg} /$ dia para as dietas com 15, 30 e 45\% de grão de concentrado. Também não foi observado efeito sobre produção e composição do leite A relação volumoso/concentrado da dieta foi de 50/50 (MORA; LEÃO; VALADARES FILHO, 1996).

\section{Farelo de algodão na alimentação de vacas leiteiras}

A substituição de ingredientes tradicionais por subprodutos pode ser uma alternativa para a atividade leiteira no Brasil. Essa prática torna-se vantajosa tanto para o produtor de leite, que ao adequar os níveis nutricionais obtêm alimento mais barato, quanto para o setor agrícola, pois é destino para os subprodutos do processamento do ingrediente inicial.

$\mathrm{Na}$ alimentação para vacas leiteiras, o farelo de algodão é normalmente utilizado em substituição ao farelo de soja, principalmente em regiões onde há plantio de algodão, onde a disponibilidade é alta e o preço torna-se competitivo com relação a demais fontes proteicas (BLACKWELDER et al., 1998).

O caroço de algodão é utilizado na alimentação de vacas leiteiras como fonte de proteína degradável no rúmen, fibra e energia. O farelo de algodão é o produto resultante da retirada do óleo do caroço após tratamento térmico. Assim, quando exposta ao calor, a proteína do caroço é desnaturada, reduzindo a degradabilidade ruminal pelas proteases microbianas (NOFTSGER et al., 2000), tornando-se fonte de proteína não degradável no rúmen. 
Comparado ao farelo se soja, o farelo de algodão possui menor teor de PB e energia e maior teor de fibra. Ainda, o perfil aminoacídico do farelo de algodão apresenta menores teores de lisina e metionina em porcentagem da proteína bruta do que o farelo de algodão. Por esses motivos a substituição total do farelo de soja por farelo de algodão na alimentação de vacas leiteiras não é possível sem que haja queda do desempenho (BLACKWELDER et al., 1998). Por outro lado, outros estudos sugerem que é possível manter a produtividade dos animais com a substituição de farelo de soja por farelo de algodão em dietas com teor proteico acima de $16 \%$ (VAN HORN et al., 1979; SANCHEZ; CLAYPOOL, 1983; BERNARD, 1997).

Em estudos realizados com vacas em lactação com produção de $27 \mathrm{~kg}$ de leite/dia, Chiou et al. (1997) não observaram efeitos da inclusão de $10 \%$ de farelo de algodão na dieta sobre a produção e composição do leite, eficiência alimentar e consumo de matéria seca, quando comparado à dieta com farelo de soja. Com inclusões de 16\%, 24,2\% e 45\% de farelo de algodão na dieta também não foram descritos efeitos deletérios sobre o metabolismo e desempenho animal (GRINGS et al., 1991; BLACKWELDER et al., 1998).

Além dos teores nutricionais do farelo de algodão, outra preocupação quando utilizados derivados do algodão é a presença de um fator antinutricional - gossipol (MENA et al., 2001; SANTOS et al., 2002, 2003a; PRIETO et al., 2003). O gossipol é um aldeído polifenólico de cor amarelada encontrado no algodão, presente principalmente nas pequenas glândulas pigmentadas da semente (DANKE et al., 1965), e pode estar presente tanto na forma livre quanto ligado a outros componentes (MENA et al., 2001). Quando o caroço de algodão está na forma bruta, sem processamento, o gossipol encontra-se na forma livre. No entanto, com o processamento do grão para obtenção do farelo de algodão, o gossipol passa a se ligar às proteínas (MENA et al., 2001).

$\mathrm{Na}$ forma ligada às proteínas, o gossipol é menos absorvido pelo trato digestivo. Porém, se houver quebra dessas ligações, o gossipol se torna livre e disponível para absorção intestinal. Os efeitos tóxicos da forma livre do gossipol estão relacionados à redução da capacidade de eritrócitos de carrear oxigênio para os tecidos pela corrente sanguínea, podendo ser observado em necropsia como edema pulmonar (BLACKWELDER et al., 1998).

Prieto et al. (2003) estudaram o efeito da inclusão de 12,8\% de caroço de algodão na dieta de vacas leiteiras com produção média de $38 \mathrm{~kg} /$ dia de leite. A fragilidade de eritrócitos não foi alterada conforme o aumento na ingestão de gossipol (livre e isômero negativo). A ausência de sintomas de intoxicação sugere que a concentração plasmática de total deste composto por si só não é um indicativo adequado para se determinar as doses seguras de inclusão de produtos originados do algodão na dieta de vacas leiteiras. 
Mena et al. (2001) observaram fragilidade ligeiramente maior de eritrócitos quando forneceram para vacas em lactação dieta contendo $15 \%$ de caroço de algodão e $7 \%$ de farelo de algodão na MS (consumo, em MS, de 3,6 kg/dia e 1,7 kg/dia, respectivamente), levando a ingestão diária de 46 gramas de gossipol total, sendo 25 gramas da molécula na forma livre e 21 gramas na forma ligada. Esses resultados diferem dos descritos por Barraza et al. (1991), onde 16 vacas em lactação que consumiram dietas com $15 \%$ de caroço de algodão e $15 \%$ de farelo de algodão ingeriram diariamente 58 gramas de gossipol total e 23 gramas de gossipol livre, mas não apresentaram sinais de intoxicação. Mena et al. (2001) sugeriram que a duração de pesquisas com animais recebendo altas doses de gossipol na dieta deve ser estendido para avaliar os efeitos nocivos deste composto a longo prazo. Foi proposto por esses autores que a detoxificação do rúmen é reduzida quando a taxa de passagem é aumentada, por promover maior chegada do gossipol ao intestino, onde é absorvido.

\section{Cenário econômico da atividade leiteira}

No Brasil, a cadeira industrial do leite está presente em todo o território e é atividade geradora de renda e de empregos. Segundo o Censo Agropecuário de 2006 (INSTITUTO BRASILEIRO DE GEOGRAFIA E ESTATÍSTICA - IBGE 2006), do total de 5,20 milhões de estabelecimentos agropecuários, 1,36 milhões (26\%) possuíam participação na pecuária leiteira em geral, sendo 1,34 milhões correspondentes a leite de vacas.

Com produção de 32,1 bilhões de litros, o Brasil ocupa o terceiro no ranking mundial de produção de leite, aproximando-se dos Estados Unidos e Índia (IBGE 2011). No entanto, esse cenário é recente, sendo que em 2004 o país ocupava o sexto lugar, com produção de 23,5 bilhões de litros (IBGE, 2005). A década de 1990 foi considerada um marco na cadeia agroindustrial do leite em função de políticas governamentais sobre a economia nacional. Em 1991 houve fim da fixação de preços do leite pelo Estado. Até então a atividade leiteira encontrava-se estagnada, com baixas taxas de crescimento de rebanho e de produção, com baixos índices zootécnicos e pouca especialização, com produtos finais de baixa qualidade (Martins. 2002).

Com a criação do Plano Real em 1994, as importações de leite aumentaram de forma descontrolada, para impedir a elevação dos preços internos, correspondendo a cerca de $20 \%$ da produção nacional (Gomes, 2002). As importações em grande escala, mesmo em períodos de 
safra da produção nacional, contribuiu para a queda e tornou o preço do leite no Brasil instável, o que inviabilizou a atividade provocando o êxodo rural. No mesmo período, no início da década de 1990, houve a abertura da economia brasileira ao MERCOSUL, o que gerou uma concorrência de grandes empresas e de preços praticados no mercado internacional. Dessa forma o produtor se deparou com um desafio de vencer as restrições de baixa qualidade além de baixa produtividade.

As transformações estruturais que ocorreram no setor leiteiro, impulsionadas pela concorrência de mercados internacionais, favoreceram a queda da renda líquida do produtor de leite no Brasil. De acordo com Gomes (2001) a queda na renda líquida pode ser explicada principalmente pela deterioração dos valores de troca (preço recebido/preço pago pelo litro de leite), por redução do preço recebido pela menor qualidade do leite ou pelo aumento do preço pago para a produção do leite.

A renda do produtor de leite, além de ser influenciada pelos termos de troca, pode sofrer efeitos individuais de produção, como a produtividade de seu rebanho e a produção total de leite. Na década de 1990 a produtividade cresceu 5,4\% com concomitante redução de 2,0\% no tamanho do rebanho, consequência de investimentos e utilização de sistemas mais intensivos de produção (Gomes, 2001). Em 1998, quando foram adotadas práticas de manejo visando à melhoria da qualidade sanitária do leite e um produto competitivo em relação a de outros países, com a utilização de resfriamento do leite na fazenda e o transporte a granel, o volume médio de produção por empresa rural gerou maiores condições do aumento de produtividade. No entanto, os ganhos por produtividade e qualidade não foram suficientes para compensar a queda dos termos de troca, resultando em redução da renda líquida e empobrecimento do produtor de leite. Souza (2002), afirma que além do preço pago ao produtor pelo litro de leite, o nível de tecnologia e produtos utilizados também contribui para aumentar ou reduzir a renda líquida do produtor. A escolha dos ingredientes e insumos pode tornar o produtor pouco competitivo, reduz as receitas e pode ser decisivo na manutenção na atividade.

Assim, se por um lado em um primeiro momento a abertura comercial e globalização contribuíram para a invasão de produtos estrangeiros e desvalorização dos produtos nacionais, ao mesmo tempo contribuiu para a profissionalização da atividade, obrigando os produtores a investir na produção. Com isso, apesar das diversas transformações e intervenções no setor, a produção de leite vem crescendo. Nos últimos 10 anos a produção de leite no Brasil cresceu $55 \%$. No entanto, o setor leiteiro ainda enfrenta desafios em termos de produtividade, com uma das menores produtividades do mundo, de 1.381 litros de leite.vaca ${ }^{-1}$.ano ${ }^{-1}$ (FAO, 2010). 
$\mathrm{O}$ aumento da produtividade depende de diversos fatores, entre eles a genética, manejo e nutrição. A alimentação das vacas é o insumo de maior custo na atividade leiteira, portanto, o gerenciamento eficiente é fundamental para a lucratividade. Ao analisar o custo de alimentação de um rebanho deve-se levar em consideração não apenas o custo total da dieta, mas também o consumo das vacas, a produção, qualidade (contagem bacteriana total e contagem de células somáticas) e composição do leite (teor de gordura e proteína), visando obter maior eficiência alimentar. Além disso, os custos com a alimentação de um rebanho são os custos com maior variabilidade e comportamento heterogêneo entre as diversas empresas rurais (MACEDO et al., 2007).

Barbosa Silveira et al. (2011), ao considerarem apenas os custos variáveis totais (CVT), a alimentação foi responsável por $71,5 \%$ destes custos. Resultados semelhantes foram encontrados por Lopes et al. (2005), os quais relataram que a alimentação de vacas de leite totalmente confinadas representa $66,5 \%$ do custo operacional efetivo. Ao se avaliarem de forma isolada os custos nutricionais, observaram-se as seguintes proporções médias para cada ingrediente: grão de soja 34,5\%, grão de milho 23,0\%, silagem de milho 19,6\%, pré-secado $9,1 \%$, sal mineral 7,5\%, farelo de soja 3,8\%, bicarbonato de sódio $1,3 \%$ e casca de soja 1,1\%. Dada a alta contribuição da nutrição para o COT, e levando-se em consideração que o grão de soja, o milho e a silagem são as principais variáveis determinantes deste custo, pode-se inferir que distorções de preços destes insumos podem influenciar de maneira significativa os custos de produção e, consequentemente, a resposta econômica do sistema produtivo adotado.

Os custos com alimentação são compostos principalmente do concentrado. No entanto, a avaliação da economicidade no uso de concentrados está diretamente relacionada à qualidade e custo do volumoso (Gomes, 2000a). Em rebanhos mais produtivos o custo da dieta por animal é mais elevado, mas é diluído no custo total por litro de leite, visto que o custo por litro de leite é menor nesses casos (CEPEA, 2007). Costa et al. (2011) descreveram aumentos da produção de leite quando o concentrado na dieta foi aumentado, porém a proporção de leite por quilo de concentrado reduziu na mesmo proporção. Isso indica que parte do concentrado pode não ser utilizada para a produção de leite. Com esse parâmetro foi definida uma equação com a finalidade de adequar a quantidade de concentrado para determinada produção de leite, levando em consideração o preço máximo do concentrado (PMC), produção de leite por quilo de concentrado (plc) e o preço pago pelo litro de leite (PL), onde: PMC = plc x PL.

Nussio e Nussio (2003), utilizando as exigências nutricionais e os valores nutritivos de alimentos concentrados, avaliaram a produtividade e a receita com a utilização de forrageiras para vacas em dois níveis de produção $\left(15\right.$ e $\left.25 \mathrm{~kg} \cdot \mathrm{dia}^{-1}\right)$ e verificaram que o fornecimento de 
silagem de milho proporcionou menor custo com alimentação, pela maior proporção de volumoso e menor uso de concentrados. No entanto, quando avaliada a receita por unidade de área, a utilização da cana de açúcar apresentou melhor resultado.

A utilização da silagem de milho como volumoso é susceptível à época do ano, fatores climáticos, por isso ocorre grande variação no custo de produção (FATURI et al., 2003). Barbosa Silveira et al. (2011) simularam diferentes custos de produção da silagem de milho nas diferentes épocas do ano, e relataram que as alterações neste custo de produção influenciam de forma significativa os indicadores econômicos de uma propriedade produtora de leite. Para períodos de entressafra, vários trabalhos técnicos têm mostrado que durante o período da seca, dentre as opções testadas de sistemas de produção de volumosos para alimentação suplementar de vacas em lactação, o fornecimento de cana de açúcar picada com uréia e enxofre, tem mostrado vantagens econômicas diante dos outros volumosos (NUSSIO et al., 2000). Segundo Costa (2004) e Oliveira (2005), a cana de açúcar pode ser competitiva economicamente mesmo exigindo maior quantidade de concentrado para suprir suas deficiências nutricionais.

À semelhança da sazonalidade de volumoso, o preço de alimentos concentrados também varia conforme ao período do ano. Grande parte dos alimentos utilizados como fonte proteica e energética na ração para bovinos leiteiros são alimentos cujo foco de produção é destinado ao consumo humano, e a utilização para alimentação animal é proveniente dos subprodutos do processamento. O farelo de soja é um dos principais alimentos proteicos disponíveis para a alimentação de bovinos (CAMPOS et al., 1998), porém, um dos limitantes do seu uso nas rações é o alto preço, implicando em aumento do custo de produção. Por outro lado, a ureia pecuária é uma fonte de nitrogênio não proteico, utilizado exclusivamente na alimentação de ruminantes.

Considerando o preço do quilo de proteína bruta da uréia em relação do farelo de soja ou de qualquer outro concentrado proteico de origem animal ou vegetal a relação será, por muito tempo ainda, favorável à uréia. Analisando-se os preços médios no ano de 2003 corrigidos para abril de 2004 pelo IGP-DI, do farelo de soja e da uréia, o custo da unidade de proteína bruta foi quatro vezes menor para a uréia (CEPEA, 2004; FNP, 2004). Entretanto, o preço da uréia subiu 38,2\% em valores reais, corrigidos pelo INPC entre os anos de 2002 e 2012 (CEPEA 2012), representando, a adição de 1\% da mistura uréia + sulfato de amônio (9:1) à cana de açúcar, $26,86 \%$ do custo total por tonelada de matéria seca da cana-de-açúcar corrigida, indicando que o desperdício não seria recomendado. Rangel et al. (2008) comparando a viabilidade econômica da substituição do farelo de soja por ureia em vacas alimentadas com cana de açúcar, observaram que dietas com ureia, apesar do maior gasto com 
volumoso, tiveram menor custo pela substituição da proteína verdadeira do farelo de soja pelo nitrogênio não proteico.

Para OLIVEIRA et al. (2001), o desempenho técnico-econômico da atividade leiteira pode ser avaliado por meio de vários índices técnicos, da relação entre eles e também pela análise econômica. Como índice técnico tem-se utilizado dentre outros a produção média por vaca em lactação/dia, a produção média diária pelo total de vacas do rebanho, a produção de leite por hectare/ano, o intervalo entre partos, os litros por quilo de concentrado fornecido e a mão-de-obra por litro de leite produzido (MARTINS, 1988; GOMES, 1997; SCHIFFLER, 1998). Na análise de desempenho econômico, os principais indicadores utilizados têm sido a Margem Bruta e a Margem Líquida. 
CAPÍTULO 2: Farelo de algodão e grão de soja cru integral em dietas com cana de açúcar para vacas leiteiras: frações nitrogenadas do leite, balanço de nitrogênio e perfil metabólico.

\section{RESUMO}

Objetivou-se avaliar o efeito de dois teores de proteína bruta (PB) (130 e 148 g de PB/kg de MS) e duas fontes nitrogenadas principais (grão de soja cru integral e farelo de algodão) na dieta de vacas leiteiras, utilizando cana de açúcar como volumoso, sobre as frações nitrogenadas do leite, balanço de nitrogênio e perfil metabólico. Foram utilizadas 12 vacas da raça Holandesa com 155 ( \pm 65 ) dias em lactação, agrupadas em três quadrados latinos 4x4 contemporâneos, com período experimental de 21 dias, sendo 14 dias para adaptação às dietas e os sete últimos para a realização das coletas. As vacas foram alojadas em baias individuais e alimentadas ad libitum com 4 dietas com duas fontes nitrogenadas principais (farelo de algodão 38 e grão de soja cru integral) e dois teores de PB (130 e 148 g/kg de MS) na dieta. As amostras de leite para análise do balanço nitrogenado e frações nitrogenadas foram coletadas no $15^{\circ}$ dia de cada período. $\mathrm{O}$ consumo e o balanço de nitrogênio foram maiores para vacas alimentadas com dietas com $148 \mathrm{~g}$ PB/kg de MS. Por outro lado, vacas alimentadas com dietas contendo farelo de algodão apresentaram maior excreção de nitrogênio no leite do que vacas alimentadas com grão de soja cru integral. A relação entre caseína e proteína verdadeira no leite foi maior em vacas alimentadas com grão de soja cru integral. Houve interação entre fonte nitrogenada e teor de $\mathrm{PB}$ da dieta sobre o nitrogênio ureico no leite (NUL) e nitrogênio não proteico (NNP). O NUL foi maior em vacas alimentadas com farelo de algodão e com maior teor de PB, em contrapartida houve menor excreção de NUL em vacas alimentadas com grão de soja com maior teor proteico. Não houve efeito das dietas sobre os teores de proteína do leite, NNC, caseína e proteína do soro. Em contrapartida, em dietas com grão de soja cru integral a maior eficiência foi observada em dietas com 148 g de PB/kg. Conclui-se que a utilização de concentrações de proteína de $130 \mathrm{~g} / \mathrm{Kg}$ na MS não altera as frações proteicas do leite de vacas leiteiras em comparação com teores de $148 \mathrm{~g} / \mathrm{Kg}$ de PB na MS, além da menor excreção de nitrogênio no ambiente.

Palavras-chave: Fontes proteicas. Vacas leiteiras. Balanço nitrogenado. Perfil metabólico. 


\begin{abstract}
The objective of this study was to evaluate the effect of two crude protein (CP) levels and two nitrogen sources in the diets of dairy cows using sugar cane as forage on milk nitrogen fraction, nitrogen balance and metabolic parameters. Twelve Holstein cows with $155( \pm 65)$ days in lactation were distributed into three contemporary $4 \times 4$ Latin squares, with experimental period of 21 days, 14 days for diet adaptation and the remaining seven for sampling. Cows were housed in individual pens and fed "ad libitum" 4 diets containing two nitrogen sources (cottonseed meal 38\% and whole raw soybean) and two levels of CP (130 and $148 \mathrm{~g} / \mathrm{Kg} \mathrm{DM}$ ). Milk samples for nitrogen balance, milk nitrogen fractions and microbial protein synthesis analysis were collected on the 15th day of each experimental period. Nitrogen intake and nitrogen balance were higher for cows fed the $148 \mathrm{~g} \mathrm{CP} / \mathrm{kg}$ DM diet. However cows fed cottonseed meal diets had higher nitrogen in milk than cows fed the whole raw soybean diet. Feces and urine excretion did not differ between diets. The casein:true milk protein ratio was higher for cows fed whole raw soybean diets. Interactions between the nitrogen source and the diet $\mathrm{CP}$ content on the milk urea nitrogen and non-protein nitrogen. Milk urea nitrogen were higher in cows fed cottonseed meal and higher concentrations of CP diets, however lower milk urea nitrogen (MUN) was observed in cows fed whole raw soybean and higher concentration of CP diets. The crude protein, non-casein protein, casein and whey protein in milk did not differ between diets. Therefore, for the whole raw soybean diets higher efficiency were obtained in diets with $148 \mathrm{~g} \mathrm{CP} / \mathrm{kg}$. In conclusion the use of low concentrations of protein $(130 \mathrm{~g} / \mathrm{Kg}$ in $\mathrm{MS})$ does not affect the nitrogen fraction of milk of dairy cows and provides lower excretion of nitrogen in the environment.
\end{abstract}

Keywords: Protein sources. Dairy cows. Nitrogen balance. Metabolic profile. 


\subsection{INTRODUÇÃO}

O excesso de proteína na dieta de vacas leiteiras resulta em ineficiência de utilização do nitrogênio para a produção de leite. O nível de inclusão de proteína nas dietas deve ser de acordo com a disponibilidade de nitrogênio para os microrganismos ruminais, visto que essa é a maior fonte de aminoácidos para a produção de proteína do leite. Assim, as formulações de dietas devem ser baseadas nas exigências de proteína degradável no rúmen (PDR) e proteína não degradável no rúmen (PNDR), para maximizar os processos fermentativos das bactérias ruminais (MOREIRA et al., 2001). A PDR deve suprir as exigências da microbiota ruminal, enquanto a PNDR deve complementar a proteína de origem microbiana que chega ao abomaso. Para maximizar a síntese de proteína microbiana, é necessário disponibilizar quantidade e qualidade de PDR associadas a fontes de carboidratos facilmente degradáveis no rúmen para possibilitar o crescimento microbiano (RUSSELL et al.,1992).

A cana de açúcar apresenta elevado potencial de produção de matéria seca e energia por área, eficiente capacidade de armazenamento de nutrientes, mantendo-se nutritiva durante todo o ano, além de ter digestibilidade total aumentada com o avanço da maturidade, diferentemente de outras gramíneas. Por outro lado, uma das limitações nutricionais da cana de açúcar é a redução do consumo de matéria seca (VALADARES FILHO; PINA, 2002) e o baixo teor de proteína bruta $(\mathrm{PB})$, o qual não atende as exigências de vacas leiteiras, independentemente da categoria de produção e estágio de lactação (PEREIRA, 1996). Como alternativa para estas limitações pode-se reduzir o uso da cana de açúcar na dieta e aumentar da fração do concentrado, o que resulta em aumento do teor de energia e proteína, redução do teor de fibra e consequentemente aumento do consumo de MS.

Alguns estudos substituíram gradativamente a silagem de milho por cana de açúcar com o volumoso e avaliaram o CMS, produção e composição do leite e variáveis ruminais (PRESTON, 1982; MAGALHAES et al., 2004; MENDONÇA et al., 2004). Entretanto, poucos estudos avaliaram a qualidade do leite, principalmente quanto à composição da fração nitrogenada do leite e o balanço nitrogenado em dietas com cana de açúcar para vacas leiteiras (ROSELER et al., 1993; BAKER et al., 1995; AQUINO et al., 2007).

De acordo com o NRC (2001), o farelo de algodão apresenta teor mais elevado de PNDR que o farelo de soja, o que permitiria maior fluxo de proteína metabolizável para o intestino e menor perda de nitrogênio ruminal, quando comparado ao farelo de soja. Entretanto, as concentrações de proteína e energia do farelo de algodão são inferiores as do farelo de soja. Por outro lado, o grão de soja cru, além de ser considerado um ingrediente de elevado teor 
proteico com proteína de alto valor biológico (39\% de PB) é também uma boa fonte de energia devido ao teor elevado de óleo encontrado no interior do grão.

Assim, a hipótese do presente estudo é de que em dietas a base de cana de açúcar como volumoso, as vacas leiteiras em estágio intermediário de lactação alimentadas com menor teor de proteína bruta e com fontes proteicas com menor degradabilidade apresentam maior eficiência do uso de nitrogênio da dieta e menores perdas de nitrogênio para o ambiente.

\subsection{OBJETIVOS}

Objetivou-se avaliar o efeito de dois teores de PB (130g vs. $148 \mathrm{~g} / \mathrm{Kg}$ de MS) e duas fontes nitrogenadas principais (farelo de algodão 38 e grão de soja cru e integral) na dieta de vacas leiteiras em lactação sobre as frações nitrogenadas do leite, balanço de nitrogênio e perfil metabólico.

\subsection{MATERIAL E MÉTODOS}

\section{Local, Instalações e Animais}

O estudo foi realizado nas instalações do setor de Bovinocultura de Leite, da Prefeitura do Campus Administrativo de Pirassununga-SP (PCAPS), da Universidade de São Paulo. Foram utilizadas 12 vacas da raça Holandesa com peso vivo médio de $550 \mathrm{~kg}$, em estágio intermediário de lactação (155 dias \pm 65 dias de lactação) e $19 \mathrm{~kg}$ de leite/dia no início do experimento. As vacas foram alojadas em baias individuais, agrupadas em três quadrados latinos $4 \times 4$, contemporâneos e balanceados de acordo com dias em lactação e produção de leite. O experimento foi realizado em quatro períodos, com duração de 21 dias cada, sendo os 14 primeiros dias de adaptação às dietas e os demais para coleta de amostras. O arranjo dos tratamentos foi o fatorial $2 \times 2$, com duas fontes nitrogenadas principais (grão de soja cru integral e farelo de algodão 38) e dois teores de PB (130g e 148g/kg de MS). 


\section{Dietas}

As vacas foram distribuídas aleatoriamente dentro do delineamento em quadrado latino para receber as seguintes dietas em esquema fatorial $2 \times 2$ :
A) Baixa PB: 130g de PB /Kg de MS e grão de soja cru integral como fonte proteica;
B) Alta PB: $148 \mathrm{~g}$ de PB /Kg de MS e grão de soja cru integral como fonte proteica;
C) Baixa PB: 130g de PB /Kg de MS e farelo de algodão como fonte proteica;
D) Alta PB: $148 \mathrm{~g}$ de PB /Kg de MS e farelo de algodão como fonte proteica.

Foi utilizado como volumoso a cana de açúcar (Saccharum spp.), na proporção volumoso:concentrado 45:55 (base na MS). A cana de açúcar foi colhida manualmente no dia anterior à sua utilização, armazenada no próprio canavial até a picagem no dia seguinte por picadeira/ensiladeira, em fragmentos de 0,5 a 1,0 cm. As dietas e água foram fornecidas ad libitum. A ingestão de MS foi ajustada diariamente a partir do percentual de sobras do dia anterior, de forma a permitir sobras de 5 a $10 \%$.

A proporção dos ingredientes no concentrado, a composição bromatológica dos ingredientes e das dietas estão apresentados nas tabelas 1 e 2 .

Tabela 1 - Composição bromatológica dos ingredientes das dietas expressa em g/Kg de MS

\begin{tabular}{lccccc}
\hline \multicolumn{1}{c}{ Composição Química } & $\begin{array}{c}\text { Cana de } \\
\text { açúcar }\end{array}$ & $\begin{array}{c}\text { Farelo } \\
\text { Soja }\end{array}$ & Fubá Milho & Grão Soja & $\begin{array}{c}\text { Farelo } \\
\text { Algodão }\end{array}$ \\
\hline Matéria Seca & 272,70 & 909,27 & 878,60 & 916,50 & 906,69 \\
Matéria Orgânica & 969,80 & 936,8 & 944,00 & 95,0 & 977,48 \\
Matéria Mineral & 33,5 & 63,2 & 56,00 & 50,0 & 22,51 \\
Proteína Bruta & 35,20 & 454,80 & 77,7 & 379,40 & 380,0 \\
Extrato Etéreo & 14,00 & 28,84 & 39,60 & 22,0 & 15,90 \\
Fibra Detergente Neutro & 556,20 & 328,59 & 94,84 & 423,7 & 292,00 \\
Fibra Detergente Ácido & 365,80 & 173,98 & 84,06 & 176,45 & 174,20 \\
Nitrogênio Insolúvel Detergente Neutro & 20,70 & 9,00 & 29,62 & 40,51 & 37,15 \\
Nitrogênio Insolúvel Detergente Ácido & 14,20 & 8,40 & 18,23 & 20,69 & 18,15 \\
Fibra Detergente Ácido indigestível & 203,40 & 14,20 & 12,20 & 16,60 & 85,00 \\
Lignina & 46,00 & 11,16 & 20,95 & 36,60 & 52,90 \\
\hline
\end{tabular}


Tabela 2 - Composição bromatológica das dietas expressas em g/Kg de MS, de acordo com a fonte nitrogenada principal e dois teores de PB

\begin{tabular}{|c|c|c|c|c|}
\hline \multirow{3}{*}{ Ingredientes } & \multicolumn{4}{|c|}{ Dietas } \\
\hline & \multicolumn{2}{|c|}{ Grão de soja } & \multicolumn{2}{|c|}{ Farelo de algodão } \\
\hline & Baixa $^{1}$ & Alta $^{2}$ & Baixa $^{1}$ & Alta $^{2}$ \\
\hline & \multicolumn{4}{|c|}{$g / K g M S$} \\
\hline Cana-de-açúcar & 449,90 & $449,90^{\circ}$ & 450,10 & 450,00 \\
\hline Milho Fubá & 340,00 & 299,20 & 345,10 & 303,80 \\
\hline Farelo de Soja $48 \%$ & 30,20 & 50,10 & 30,40 & 50,10 \\
\hline Grão de Soja & 120,10 & 139,90 & - & - \\
\hline Farelo de Algodão 38\% & - & - & 113,70 & 135,10 \\
\hline Uréia & 8,00 & 9,10 & 8,00 & 9,10 \\
\hline Sulfato de Amônia & 1,70 & 2,30 & 1,70 & 2,30 \\
\hline Mistura mineral & 19,90 & 19,90 & 20,00 & 19,90 \\
\hline Bicarbonato de Sódio & 8,00 & 8,00 & 8,00 & 8,00 \\
\hline Óxido de Magnésio & 2,30 & 2,30 & 2,30 & 2,30 \\
\hline Fosfato Bicálcico & 8,00 & 8,00 & 8,00 & 8,00 \\
\hline Calcário & 6,30 & 6,30 & 6,40 & 6,30 \\
\hline Sal comum & 2,80 & 2,30 & 3,70 & 2,30 \\
\hline \multirow[t]{2}{*}{ Cloreto de Potássio } & 2,80 & 2,80 & 2,80 & 2,80 \\
\hline & \multicolumn{4}{|c|}{ Composição Química g/Kg MS } \\
\hline Matéria Seca & 609,5 & 616,6 & 619,2 & 617,3 \\
\hline Matéria Orgânica & 930,3 & 934,2 & 962,0 & 961,7 \\
\hline Matéria Mineral & 38,2 & 41,8 & 38,7 & 42,0 \\
\hline Proteína Bruta & 129,0 & 146,0 & 130,2 & 146,0 \\
\hline Extrato Etéreo & 47,0 & 50,0 & 24,0 & 23,0 \\
\hline Fibra Detergente Neutro & 323,0 & 322,0 & 343,0 & 348,0 \\
\hline Fibra Detergente Ácido & 200,0 & 203,0 & 205,0 & 215,0 \\
\hline Nitrog. Insolúvel Detergente Neutro & 27,9 & 30,2 & 28,5 & 25,9 \\
\hline Nitrog. Insolúvel Detergente Ácido & 21,0 & 26,2 & 19,0 & 2,29 \\
\hline FDA indigestível & 103,3 & 106,1 & 107,3 & 109,1 \\
\hline Lignina & 27,5 & 32,2 & 27,6 & 29,5 \\
\hline
\end{tabular}

Em cada período experimental foram coletadas amostras de cana de açúcar, dos ingredientes do concentrado e das sobras das rações fornecidas. As amostras foram armazenadas a $-20^{\circ} \mathrm{C}$ até a realização das análises bromatológicas.

Nos alimentos fornecidos e nas amostras de sobras foram analisados os teores de matéria seca (MS), matéria orgânica (MO), matéria mineral (MM), extrato etéreo (EE), proteína bruta $(\mathrm{PB})$, nitrogênio insolúvel em detergente neutro (NIDN), nitrogênio insolúvel em detergente ácido (NIDA) e lignina de acordo com as metodologias descritas pela American Association of Oficial Analytical Chemists (AOAC, 1995). O teor de proteína bruta (PB) foi obtido pela multiplicação do teor de nitrogênio total por 6,25. Os teores de fibra detergente neutro (FDN) e fibra detergente ácido (FDA) foram obtidos utilizando-se $\alpha$-amilase sem adição de sulfito de sódio na determinação do FDN, em Sistema Ankon® (VANSOEST; MASON, 
1991).

\section{Balanço de nitrogênio}

Para o cálculo de balanço de nitrogênio foi realizada a determinação da concentração de creatinina na urina (VALADARES et al., 1999b; RENNO et al., 2008) a partir de amostras spot de $50 \mathrm{~mL}$ de urina, obtidas de todas as vacas no $15^{\circ}$ dia de cada período experimental, quatro horas após a alimentação matinal, pela micção estimulada por massagem na vulva. Para as análises de ácido úrico e alantoína, $50 \mathrm{~mL}$ de urina foram filtrados e alíquotas de $10 \mathrm{~mL}$ foram diluídas imediatamente em $40 \mathrm{~mL}$ de ácido sulfúrico a $0,036 \mathrm{~N}$ para evitar destruição bacteriana dos derivados de purinas e precipitação do ácido úrico. Para a determinação dos compostos nitrogenados totais, de ureia e creatinina, $40 \mathrm{~mL}$ de urina pura de cada vaca por período foram armazenadas a $-20^{\circ} \mathrm{C}$ até o momento das análises.

As concentrações de creatinina foram determinadas por meio de kits comerciais (Laborlab®), utilizando reação enzimática colorimétrica cinética em aparelho SBA-200 CELM®. Para a realização dessa análise, $100 \mu \mathrm{L}$ de urina foram diluídos em $4.900 \mu \mathrm{L}$ de água deionizada. Os resultados obtidos foram calculados pela seguinte fórmula: creatinina $(\mathrm{mg} / \mathrm{dL})=$ creatinina (mg/dL)*0,020*50 (COOPER; BIGGS, 1961).

O volume urinário total diário foi estimado dividindo-se as excreções urinárias diárias de creatinina pelos valores observados de concentração de creatinina na urina das amostras spot, segundo Oliveira et al. (2001b). A excreção urinária diária de creatinina foi estimada a partir da proposição de 24,05 mg/kg de peso vivo (PV) (CHIZZOTTI et al., 2007; CHIZZOTTI et al., 2008). Dessa forma, com a excreção média diária de creatinina e a concentração de creatinina (mg/dL) na amostra spot de urina, foi estimado o volume total diário de urina, em litros por vaca/dia, para o cálculo do balanço de nitrogênio.

O consumo total de nitrogênio foi determinado dividindo-se o valor da PB das amostras por 6,25, obtendo-se a quantidade em gramas de nitrogênio consumida. O mesmo cálculo foi realizado com os valores de $\mathrm{PB}$ das fezes obtendo-se a excreção total de nitrogênio em g/Kg de MS.

Para a determinação do nitrogênio total das amostras de urina e leite, a quantidade em gramas de nitrogênio para cada $100 \mathrm{~mL}$ de urina ou leite foi obtida pela divisão do valor de PB 
da amostra pelo fator 6,25 para as amostras de urina e 6,38 para as amostras de leite (SILVA; QUEIROZ, 2002).

O balanço de nitrogênio foi obtido subtraindo o total de nitrogênio consumido em gramas pelos valores obtidos para nitrogênio na urina, nas fezes e no leite, obtendo-se os valores de nitrogênio retido em gramas e em porcentagem de nitrogênio total.

\section{Frações nitrogenadas do leite}

Para a determinação do nitrogênio ureico do leite, amostras compostas da ordenha completa, foram coletadas do $14^{\circ}$ ao $18^{\circ}$ dia experimental das ordenhas da manhã e tarde $(60 \%$ correspondente à ordenha da manhã e $40 \%$ à ordenha da tarde), a partir do amostrador da ordenhadeira. A concentração de NUL foi realizada pelo método enzimático espectrofotométrico de trans-reflectância em equipamento Chem-Speck 150® (BENTLEY, 1995b) no Laboratório de Fisiologia da Lactação da ESALQ - USP (Clínica do Leite).

As amostras compostas da ordenha completa foram coletadas do $18^{\circ}$ ao $21^{\circ}$ dia de cada período experimental para determinação das frações nitrogenadas do leite (nitrogênio total NT, nitrogênio não proteico - NNP e nitrogênio não caseinoso - NNC). As amostras de leite foram coletadas e armazenadas em tubos plásticos e refrigeradas a $-20^{\circ} \mathrm{C}$ até realização das análises.

A determinação da concentração de proteína do leite foi baseada na mensuração do nitrogênio total (NT) pelo método de Kjeldahl, conforme metodologia descrita pela American Association of Oficial Analytical Chemists (AOAC, 1995) pelo método 33.2.11; 991.20. Para a obtenção do resultado em PB, multiplicou-se o NT pelo fator de conversão 6,38 (BARBANO et al., 1990).

As frações de NNC e de caseína do leite foram determinadas por metodologia descrita por Lynch et al.(1998). A caseína do leite foi precipitada em $\mathrm{pH}=4,6$ usando-se solução de acido acético e acetato de sódio. Após a precipitação, a caseína foi separada por filtração e a concentração de $\mathrm{N}$ do filtrado (NNC), determinada pelo método de Kjeldahl (LYNCH et al., 1998). A concentração de caseína foi obtida pela subtração entre NT e NNC.

As frações de NNP e proteína verdadeira do leite foram determinadas de acordo com a metodologia descrita por Lynch et al. (1998), na qual a proteína verdadeira do leite é 
precipitada em solução de ácido tricloroacético a 12\%. Após a precipitação, a proteína verdadeira do leite foi separada por filtração e a concentração do $\mathrm{N}$ do filtrado (NNP) foi determinada pelo método de Kjeldahl. A concentração de proteína verdadeira do leite (PVerd) foi obtida da subtração da concentração de NT e NNP. A proteína do soro foi determinada a partir da subtração entre caseína e PVerd.

\section{Parâmetros metabólicos sanguíneos}

A coleta de amostras de sangue foi realizada no $16^{\circ}$ dia de cada período experimental por punção da veia ou artéria coccígea, anteriormente ao fornecimento das da dieta no período da manhã. As amostras foram coletadas em tubos com vácuo para dosagem dos parâmetros metabólicos sanguíneos glicose, colesterol total, colesterol HDL, ureia e nitrogênio ureico no soro, proteínas totais, albumina e as enzimas aspartato amino transferase e gama glutamil transferase no soro. Para dosagem de glicose no plasma, as amostras foram coletadas em tubos com anticoagulante fluoreto de sódio. Imediatamente após coleta, as amostras foram refrigeradas e centrifugadas a $2000 \mathrm{~g}$ durante 15 minutos para a separação do plasma. O centrifugado obtido foi transferido para tubetes plásticos, identificados e armazenados a $-20^{\circ} \mathrm{C}$, até a realização das análises laboratoriais.

As análises dos parâmetros sanguíneos foram realizadas por meio de kits comerciais (Laborlab® e CELM $\left.{ }^{\circledR}\right)$ que utilizam método enzimático colorimétrico de ponto final, sendo a leitura realizada em analisador automático de bioquímica sanguínea (Sistema de Bioquímica Automático SBA-200 - CELM®).

Para a determinação da concentração de C-HDL, $200 \mu \mathrm{L}$ da amostra foram pipetados em tubos de 2,5 mL, juntamente com $100 \mu \mathrm{L}$ do reativo único precipitante (CELM-1763) na proporção de 2:1 e misturados manualmente por inversão suave durante 20 segundos. Em seguida as amostras foram deixadas em repouso por 10 minutos, seguido por centrifugação durante 15 minutos a $2700 \mathrm{~g}$. No sobrenadante, separado pela centrifugação, restaram as moléculas de HDL ligadas ao colesterol. 


\section{Delineamento experimental e análises estatísticas}

O delineamento experimental usado foi o quadrado latino 4x4, com arranjo fatorial de tratamentos $2 \times 2$, sendo duas fontes nitrogenadas principais na dieta (grão de soja cru e farelo de algodão), dois teores de proteína bruta (130g ou $148 \mathrm{~g} / \mathrm{Kg}$ de MS) e a interação. Os resultados foram submetidos à análise estatística pelo programa SAS (Version 9.1.3, SAS Institute, Cary, NC 2004), verificando a normalidade dos resíduos e a homogeneidade das variâncias pelo Proc GLM. Os dados foram analisados de acordo com os efeitos principais de fonte e teor de proteína bruta e a interação, pelo comando Proc MIXED do SAS, adotando-se nível de significância de 5\%, de acordo com o seguinte modelo:

$$
\mathrm{Y}_{\mathrm{ijklm}}=\mu+\mathrm{F}_{\mathrm{i}}+\mathrm{T}_{\mathrm{j}}+\mathrm{F}_{\mathrm{i}} * \mathrm{~T}_{\mathrm{j}}+\mathrm{Q}_{\mathrm{k}}+\mathrm{A}(\mathrm{Q})_{1}+\mathrm{P}_{\mathrm{m}}+\mathrm{e}_{\mathrm{ijklm}}
$$

$\mathrm{Y}_{\mathrm{ijkl}}=$ é a observação referente à fonte nitrogenada;

$\mu=$ média geral;

$\mathrm{F}_{\mathrm{i}}=$ efeito da fonte nitrogenada, $\mathrm{i}$ = grão de soja cru ou farelo de algodão;

$\mathrm{T}_{\mathrm{j}}=$ efeito do teor de PB, $\mathrm{j}=$ teor de PB: $130 \mathrm{~g}$ ou $148 \mathrm{~g} / \mathrm{Kg}$ de MS;

$\mathrm{F}_{\mathrm{i}} * \mathrm{~T}_{\mathrm{j}}=$ interação entre a fonte nitrogenada e teor de PB;

$\mathrm{Q}_{\mathrm{k}}=$ efeito do quadrado latino $\mathrm{k}, \mathrm{k}=1$ a 3;

$\mathrm{A}(\mathrm{Q})_{1}=$ efeito do animal dentro de cada quadrado latino, $1=1$ a 12 ;

$\mathrm{P}_{\mathrm{m}}=$ efeito do período, $\mathrm{m}=1$ a 4 ;

$\mathrm{E}_{\mathrm{ijklm}}=$ erro aleatório associado a cada observação.

$1=$ animal dentro de quadrado latino.

Os graus de liberdade calculados foram realizados de acordo com o método Satterthwaite (DDFM = Satterth). 


\subsection{RESULTADOS}

\section{Frações nitrogenadas do leite}

As médias ajustadas das frações de proteína bruta (PB), nitrogênio não proteico (NNP), nitrogênio não caseinoso (NNC), proteína verdadeira, caseína, proteínas do soro e relação entre caseína e proteína verdadeira, estão apresentadas na tabela 3.

Tabela 3 - Efeito das duas fontes nitrogenadas (farelo de algodão e grão de soja cru integral) e teores de 130 e $148 \mathrm{~g}$ de $\mathrm{PB} / \mathrm{kg}$ de MS sobre as frações proteicas do leite em vacas leiteiras

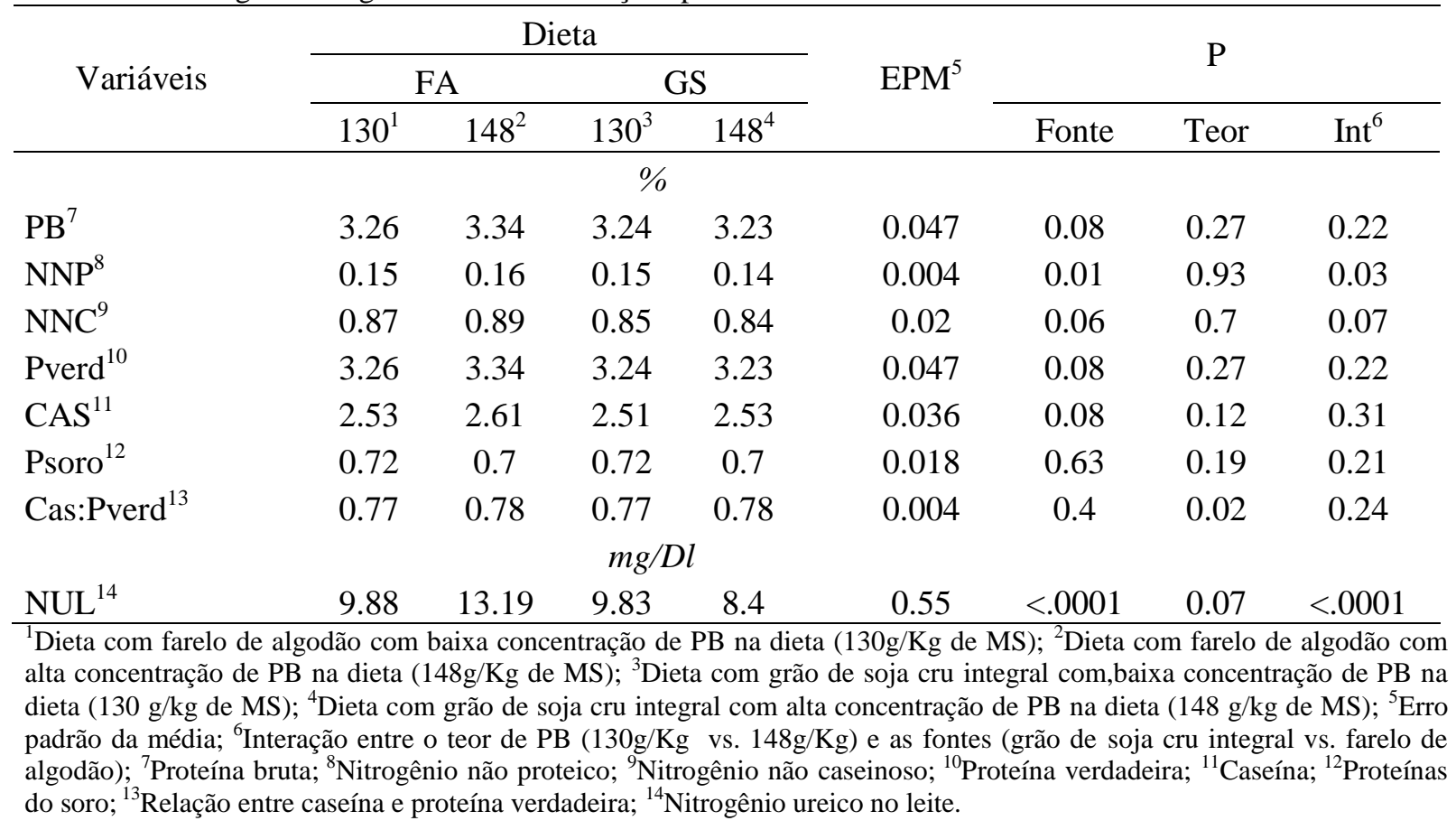

Verificou-se efeito de fonte $(\mathrm{P}=0,01)$ e interação entre teor e fonte nitrogenada $(\mathrm{P}=0,03)$ sobre o teor de NNP no leite (\%). Vacas alimentadas com dietas com farelo de algodão apresentaram leite com maior concentração de NNP do que vacas alimentadas com grão de soja. As vacas alimentadas com a dieta com FA em menor teor proteico (130g/Kg de MS) apresentaram maior excreção de NNP $(0,16 \%)$, e o inverso aconteceu em vacas alimentadas com GS, sendo maior a excreção $(0,15 \%)$ com dietas com menor teor proteico $(130 \mathrm{~g} / \mathrm{Kg}$ de MS) (Figura 1). 
Houve efeito do teor proteico das dietas sobre a relação entre caseína e proteína verdadeira do leite. Vacas alimentadas com dietas com maior teor proteico (148 g/kg de MS) apresentaram maior relação Cas:Pverd $(0,78 \%)$.

Houve efeito de interação $(\mathrm{P}<0,0001)$ entre teor e a fonte nitrogenada sobre o NU excretado no leite. As dietas contendo GS com menor teor de proteína (130 g/Kg na MS) resultaram em maior excreção $(9,83 \mathrm{mg} / \mathrm{dL})$ de NUL, e ocorreu o inverso para as vacas alimentadas com a dieta contendo FA, que foi maior $(13,19 \mathrm{mg} / \mathrm{dL})$ com o maior teor de proteína (148g/Kg na MS).

Figura 1 - Interação entre a fonte nitrogenada e o teor de proteína bruta da dieta sobre o NNP em vacas leiteiras

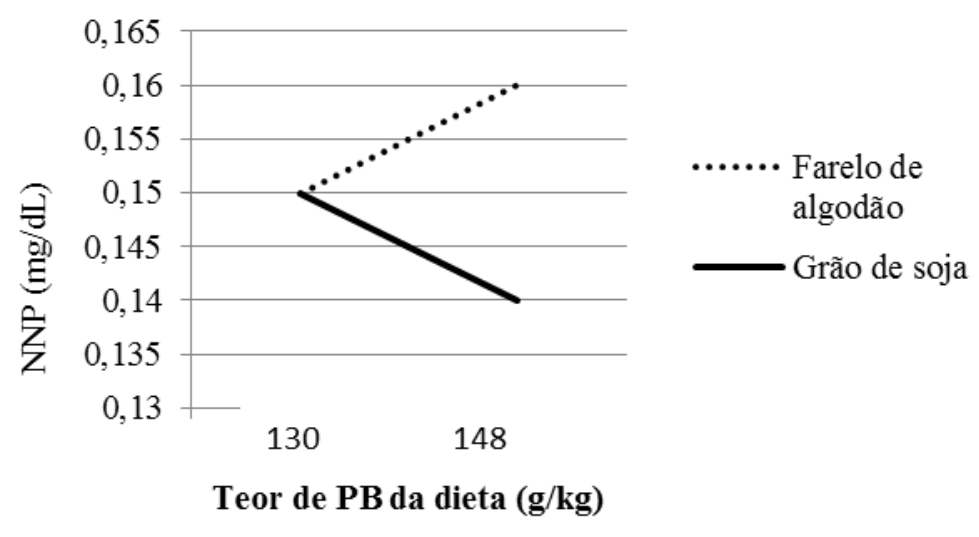

Figura 2- Interação entre a fonte nitrogenada e o teor de proteína bruta da dieta sobre o nitrogênio ureico no leite em vacas leiteiras

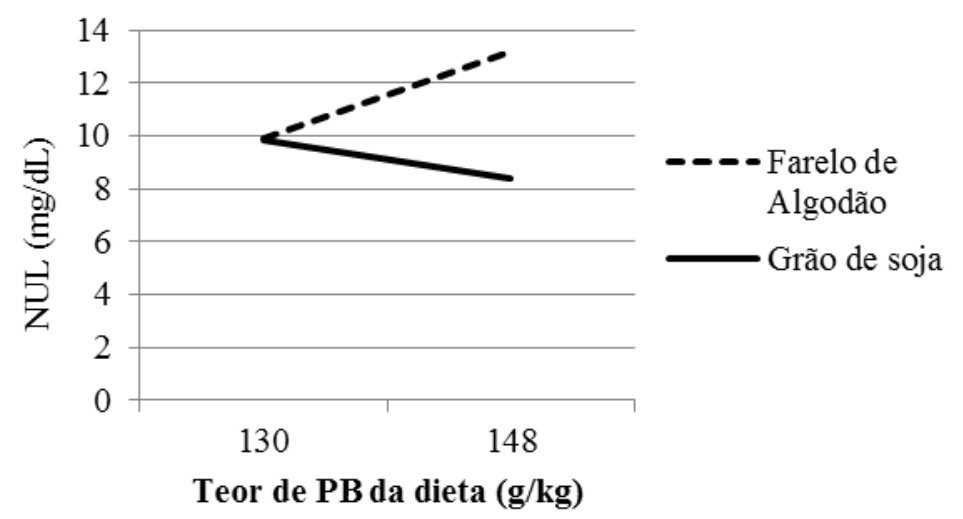




\section{Balanço de nitrogênio}

As médias ajustadas para consumo total de nitrogênio (g/dia), excreção fecal de nitrogênio (g/dia e \% $\mathrm{N}$ total), excreção urinária de $\mathrm{N}$ (g/dia e \% $\mathrm{N}$ total), e excreção de $\mathrm{N}$ no leite (g/dia e \% $\mathrm{N}$ total), balanço de nitrogênio (g/dia e \% $\mathrm{N}$ total), a eficiência de utilização do nitrogênio ( $\mathrm{g}$ de $\mathrm{N}$ no leite / $\mathrm{N}$ consumido) estão apresentados na tabela 4.

Tabela 4 - Efeito das duas fontes nitrogenadas (farelo de algodão e grão de soja cru integral) e teores de 130 e $148 \mathrm{~g}$ de $\mathrm{PB} / \mathrm{kg}$ de MS sobre o balanço de nitrogênio em vacas leiteiras

\begin{tabular}{|c|c|c|c|c|c|c|c|c|}
\hline \multirow{3}{*}{ Variável } & \multicolumn{4}{|c|}{ Dieta } & \multirow{3}{*}{$\mathrm{EPM}^{5}$} & \multirow{2}{*}{\multicolumn{3}{|c|}{$\mathrm{P}$}} \\
\hline & \multicolumn{2}{|c|}{ FA } & \multicolumn{2}{|c|}{ GS } & & & & \\
\hline & $130^{1}$ & $148^{2}$ & $130^{3}$ & $148^{4}$ & & Fonte & Teor & Int $^{6}$ \\
\hline Consumo N (g/dia) & 406,73 & 417,04 & 414,75 & 401,26 & 12,26 & 0,918 & 0,748 & 0,097 \\
\hline \multicolumn{9}{|l|}{ Excreção fecal } \\
\hline Total N, g/d & 99,28 & 110,35 & 13004 & 114,25 & 6,15 & 0,123 & 0,305 & 0,110 \\
\hline Total $\mathrm{N}, \% \mathrm{~N}$ consumido & 25,1 & 26,35 & 28,86 & 26,6 & 0,82 & 0,0282 & 0,185 & 0,306 \\
\hline \multicolumn{9}{|l|}{ Excreção urinária } \\
\hline Total N, g/d & 0,13 & 0,14 & 0,15 & 0,14 & 0,01 & 0,206 & 0,701 & 0,252 \\
\hline Total $\mathrm{N}, \% \mathrm{~N}$ consumido & 6,01 & 6,47 & 6,38 & 5,76 & 0,32 & 0,902 & 0,944 & 0,251 \\
\hline
\end{tabular}

Excreção no leite

Total N, g/d

$86,5 \quad 83,64 \quad 79,67 \quad 81,13 \quad 3,91 \quad 0,229 \quad 0,174 \quad 0,249$

Total $\mathrm{N}, \% \mathrm{~N}$ consumido

$21,67 \quad 20,42 \quad 19,69 \quad 19,36$

$0,87 \quad 0,003 \quad 0,053 \quad 0,234$

Balanço N

$\mathrm{N}$ retido, $\mathrm{g} / \mathrm{d}$

$\mathrm{N}$ retido, $\% \mathrm{~N}$ consumido

$\begin{array}{cccccccc}212,81 & 204,24 & 188,36 & 219,4 & 6,87 & 0,262 & 0,416 & 0,204 \\ 51,71 & 50,74 & 47,12 & 52,07 & 1,58 & 0,459 & 0,440 & 0,272\end{array}$

\section{Eficiência}

$\begin{array}{lllllllll}\text { g N leite/g N consumido } & 0,21 & 0,2 & 0,19 & 0,2 & 0,01 & 0,150 & 0,700 & 0,240\end{array}$

${ }^{1}$ Dieta com farelo de algodão com baixa concentração de PB na dieta (130g/Kg de MS); ${ }^{2}$ Dieta com farelo de algodão com alta concentração de PB na dieta (148g/Kg de MS); ${ }^{3}$ Dieta com grão de soja cru integral com,baixa concentração de PB na dieta (130 g/kg de MS); ${ }^{4}$ Dieta com grão de soja cru integral com alta concentração de PB na dieta (148 g/kg de MS); ${ }^{5}$ Erro padrão da média; ${ }^{6}$ Interação entre o teor de PB $(130 \mathrm{~g} / \mathrm{Kg}$ vs. $148 \mathrm{~g} / \mathrm{Kg}$ ) e as fontes (grão de soja cru integral vs. farelo de algodão).

Houve efeito $(\mathrm{P}=0,003)$ da fonte proteica sobre o nitrogênio excretado no leite (\% do $\mathrm{N}$ consumido), sendo menor em vacas alimentadas com farelo de algodão do que em vacas alimentadas com grão de soja cru integral. Os demais parâmetros não tiveram efeitos das dietas. 


\section{Parâmetros metabólicos sanguíneos}

As médias ajustadas do teor de glicose, colesterol total, HDL, ureia, nitrogênio ureico no sangue, albumina e ácidos graxos não esterificados estão apresentados na tabela 5 .

Tabela 5 - Efeito das duas fontes nitrogenadas (farelo de algodão e grão de soja cru integral) e teores de 130 e $148 \mathrm{~g}$ de $\mathrm{PB} / \mathrm{kg}$ de MS sobre os metabólitos plasmáticos em vacas leiteiras

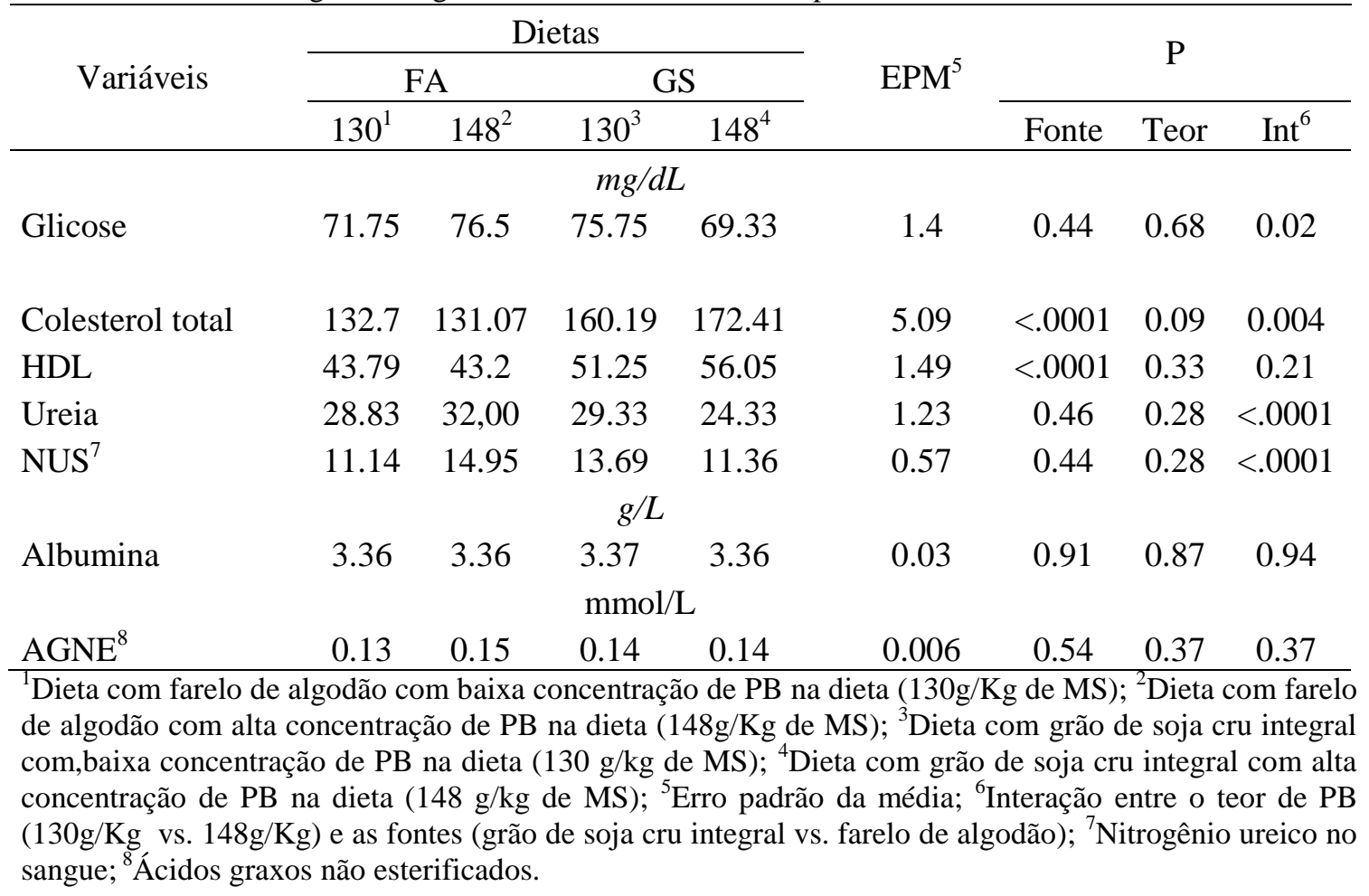

Houve interação ente fonte e teor nitrogenado sobre a concentração de glicose no sangue. Em dietas com grão de soja, a concentração de glicose reduziu com o aumento da PB da dieta de 130 para 148 g/Kg da MS. Já com o farelo de algodão, a relação foi proporcional, aumentando a concentração de glicose com o aumento do teor de PB de 130 para 148 g/Kg da MS (Figura 3). 
Figura 3 - Interação entre a fonte nitrogenada e o teor de proteína bruta da dieta sobre concentração de glicose sanguínea em vacas leiteiras

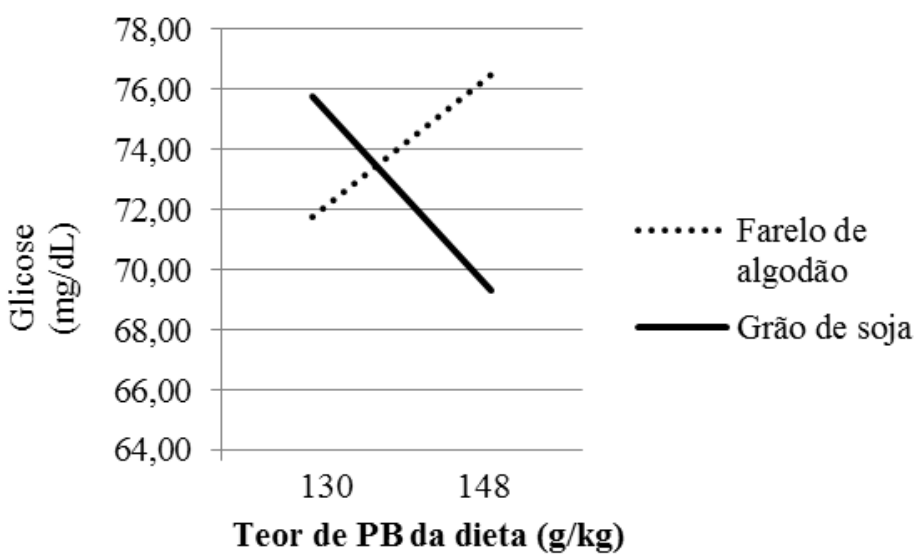

Houve efeito $(\mathrm{P}<0,0001)$ da fonte proteica sobre a concentração de colesterol total e HDL plasmático, sendo maior em vacas alimentadas com dietas com grão de soja como fonte proteica. Além disso, o colesterol total sofreu efeito de interação entre fonte e teor de proteína bruta. Nas dietas com grão de soja, o teor de colesterol total foi maior em dietas com alta proteína (148g/Kg de MS) (Figura 4).

Figura 4 - Interação entre a fonte nitrogenada e o teor de proteína bruta da dieta sobre o teor de colesterol total em vacas leiteiras

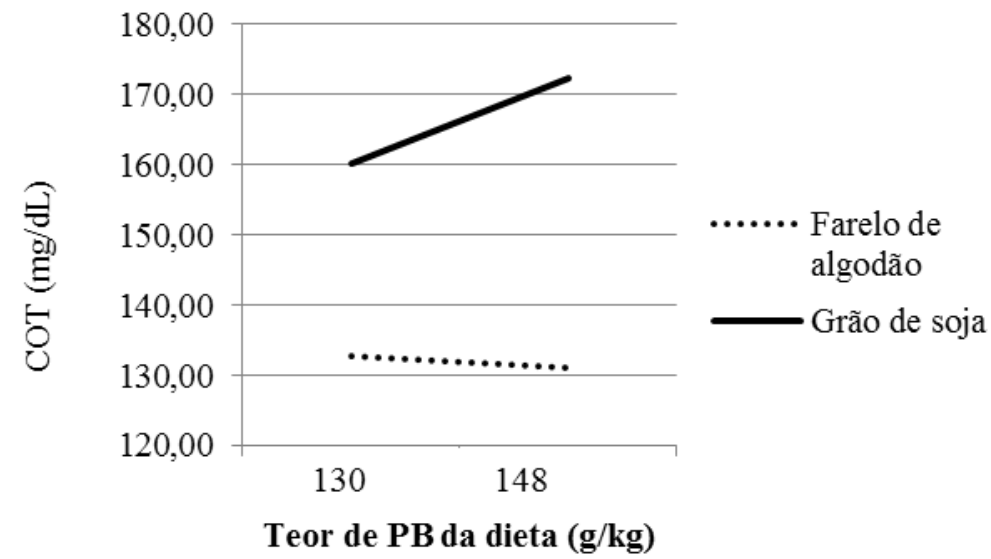

Verificou-se interação entre fonte e teor proteicos sobre o teor de ureia e nitrogênio ureico no sangue. Nas dietas com farelo de algodão o aumento do teor proteico resultou em aumento da concentração de ureia e nitrogênio ureico, enquanto nas dietas com grão de soja, o aumento do teor proteico promoveu redução nos teores de ureia e nitrogênio ureico (Figuras 5 e $6)$. 
Figura 5 - Interação entre a fonte nitrogenada e o teor de proteína bruta da dieta sobre o teor de ureia no soro em vacas leiteiras

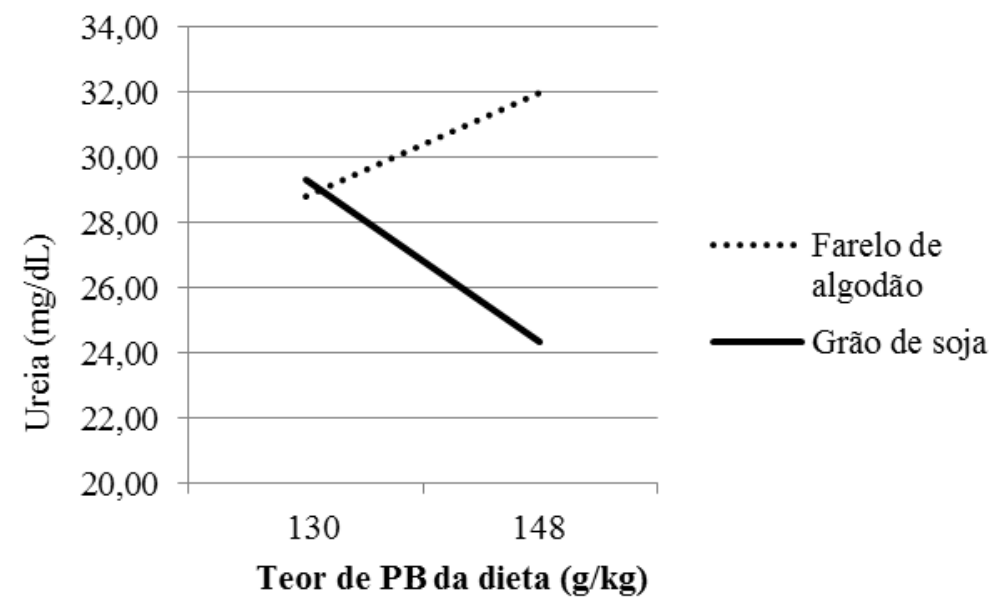

Figura 6 - Interação entre a fonte nitrogenada e o teor de proteína bruta da dieta sobre o teor de nitrogênio ureico no sangue em vacas leiteiras

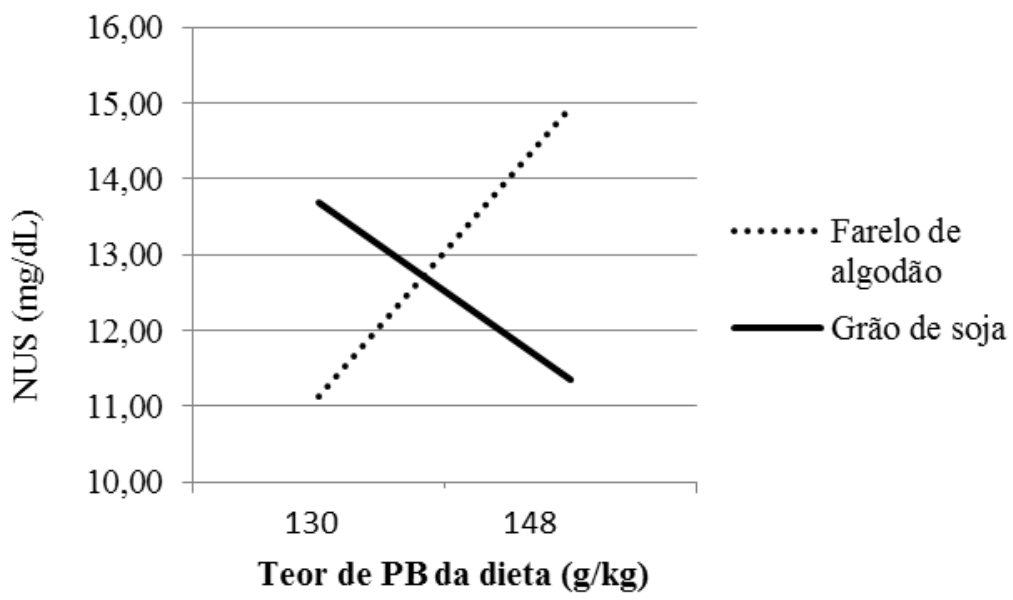




\subsection{DISCUSSÃO}

\section{Frações nitrogenadas do leite}

O NNP sofreu influência da fonte de PB da dieta, sendo maior para as dietas com farelo de algodão comparado às dietas com grão de soja (0,155\% vs. 0,145\%). Nas dietas com farelo de algodão o aumento do teor de PB de 130 para 148 g/kg de MS aumentou o teor de NNP no leite, enquanto que nas dietas com grão de soja, o aumento do teor proteico reduz o teor de NNP do leite (Tabela 4).

O farelo de algodão apresenta composição com perfil aminoacídico diferente do grão de soja. Por exemplo, os teores de arginina, histidina e fenilalanina são consideravelmente maiores no farelo de algodão do que no grão de soja. Apesar de ambas as fontes terem suprido as exigências de proteína metabolizável e aminoácidos, pois o teor de PB do leite foi semelhante entre as dietas, os aminoácidos em excesso do farelo de algodão, que não foram utilizados pela microbiota ruminal foram excretados no leite como NNP.

No presente estudo, as concentrações médias de NUL foram semelhantes às descritas em outros estudos (BRODERICK et al., 1993; LEONARDI et al., 2003; KALSCHEUR et al., 2006; CORDEIRO et al., 2007; SOUZA et al., 2009; NAVES, 2010). A maior concentração de NUL foi observada em vacas alimentadas com farelo de algodão com 140 g de PB/Kg de MS (13,19 mg/dL), sendo que esta média está de acordo com os valores entre 10 e $16 \mathrm{mg} / \mathrm{dL}$ sugeridos por Jonker, Kohn e Erdman (1998). De acordo com estes autores, o valor entre 10 e $16 \mathrm{mg} / \mathrm{dL}$ são resultado de adequado balanço de PDR e carboidrato fermentável no rúmen, com maior eficiência de utilização do nitrogênio dietético. Valores acima de $16 \mathrm{mg} / \mathrm{dL}$ podem indicar consumo de nitrogênio em excesso, por excesso de PDR.

Os teores de NUL das vacas alimentadas com deitas contendo grão de soja $(9,83$ e 8,4 mg/dL) encontraram-se abaixo da média sugerida por Jonker, Kohn e Erdman (1998). Valores abaixo de $10 \mathrm{mg} / \mathrm{dL}$ podem indicar deficiência de PB na dieta, quantidade limitada de PDR e PNDR ou alta taxa de fermentação de carboidratos não fibrosos no rúmen (JONKER et al., 1999; GODDEN ET al., 2001b). Uma das limitações de dietas com grão de soja cru integral na dieta de ruminantes é o teor de extrato etéreo da dieta que podem exercer efeito inibitório sobre o consumo. O menor teor de NUL apresentado nas dietas com grão de soja neste experimento, e a relação inversamente proporcional ao aumento do teor de $\mathrm{PB}$, podem estar relacionados ao 
menor consumo de MS provocada pela inclusão do grão.

Davidson et al. (2003) observaram médias de 15,6 a 10,7 e de 21,9 a 14,3 mg/dL de nitrogênio ureico no leite em vacas alimentadas com dietas contendo diferentes níveis de PNDR (34,0; 40,0 e 46,0\%), respectivamente. Carvalho (2005), ao fornecer dietas com diferentes níveis de PNDR de 36,5; 30,9 e 42,9\% relatou para concentrações médias de NUL de 20,17; 20,38 e 18,85 mg/dL, respectivamente. Os valores em geral descritos no presente estudo, se encontram abaixo dos encontrados pela maioria dos estudos, o que pode sugerir que as dietas não eram balanceadas adequadamente e não supriram a relação N:CHO fermentáveis no rúmen.

No presente estudo, o teor médio de caseína (2,54\%) foi superior aos relatados por Bateman II et al. (1999) (2,24\%), mas semelhantes ao de Aquino et al. (2008) (2,55\%) e Conti et al. (2011) (2,51\%). O teor de caseína do leite está relacionado com a síntese de proteína microbiana, que é de alto valor biológico, rica em aminoácidos essenciais com perfil aminoacídico semelhante ao da proteína do leite.

\section{Balanço de nitrogênio}

Não houve diferença de consumo de nitrogênio (g/dia) entre as dietas. Espera-se que dietas com maior teor proteico favoreça maior consumo proporcional de nitrogênio. No entanto, Mertens (2002) sugere que o consumo de matéria seca, e de todos os nutrientes componentes da dieta, é regulado pelas características dos alimentos. O grão de soja em alta concentração pode ser um limitante do consumo de MS pelo alto teor de EE presente no grão. Dietas ricas em energia podem limitar o consumo por atender os requerimentos energéticos antes do enchimento ruminal. Assim, apesar de o teor proteico da dieta com $148 \mathrm{~g}$ de $\mathrm{PB} / \mathrm{kg}$ MS, o consumo de N pode não ter sido maior em razão do menor consumo de MS.

As vacas alimentadas com grão de soja apresentaram menor excreção de nitrogênio total no leite ( $\mathrm{N}$ retido g/\% $\mathrm{N}$ consumido), do que as dietas com farelo de algodão (21,04 vs. 19,52). Esse resultado se relaciona com a menor excreção de NNP. O perfil aminoacídico do grão de soja pode promover melhor aproveitamento pelos microrganismos ruminais, e consequentemente reduzir a excreção de compostos nitrogenados.

No presente estudo não foram observadas diferenças entre as dietas sobre a excreção de nitrogênio urinária e fecal. Do mesmo modo, Mendonça et al. (2004) não observaram diferença de excreção de nitrogênio (g/dia) na urina, nas fezes e no leite de vacas alimentadas com 
silagem de milho com relação volumoso:concentrado (V:C) de 60:40, com base na MS, ou à base de cana-de-açúcar (CA) com relação V:C de 60:40, com 0,35 ou 1\% de ureia+sulfato de amônio (SA) ou V:C de 50:50 com 1\% de ureia+SA.

A eficiência da utilização de nitrogênio pode ser obtida pela relação entre a quantidade de nitrogênio secretada no leite e o nitrogênio ingerido pelos animais (KEBREAB et al., 2001). Castillo et al. (2000) em revisão sobre eficiência de utilização de N, relataram que a ingestão de nitrogênio em concentrações superiores a $400 \mathrm{~g} /$ dia causa aumento da quantidade de $\mathrm{N}$ excretado na urina e fezes, sugerindo um valor adequado de $15 \%$ de PB na MS para reduzir as perdas por excretas sem afetar a produtividade. No presente estudo, as médias de consumo de $\mathrm{N}$ foram de 410,74 g/dia nas dietas com $130 \mathrm{~g}$ de PB/kg MS e 409,15 g/dia para as dietas com $148 \mathrm{~g}$ de PB/kg MS, cujos valores foram similares ao recomendado por Castillo et al. (2000). No entanto não houve influência das dietas sobre as perdas por urina e fezes.

Não houve efeito das dietas sobre o balanço de nitrogênio (g/dia). Como não houve diferença de consumo de $\mathrm{N}$ e pequena diferença entre a excreção de $\mathrm{N}$ no leite, o balanço não foi alterado. Não houve balanço negativo de nitrogênio em nenhuma dieta, concluindo-se que o teor de proteína foi adequado para os níveis de produção avaliados e houve consumo suficiente para atender as exigências dos animais.

Dietas com farelo de algodão resultam em maior excreção de $\mathrm{N}$ no leite do que o grão de soja cru integral. Dietas com $130 \mathrm{~g}$ de PB/kg de MS ou 148 g de PB/kg de MS não apresentam diferenças sobre o balanço de nitrogênio.

\section{Parâmetros metabólicos sanguíneos}

Os parâmetros metabólicos sanguíneos em vacas leiteiras podem ser usados para estimar o processo de demanda metabólica a novas situações fisiológicas ou alimentares. A uréia e a albumina podem ser utilizadas para avaliação da nutrição proteica, enquanto a glicose e o colesterol, para avaliação energética da dieta.

No presente estudo, a concentração média de glicose apresentou efeito de interação entre fonte e teor proteico. A dieta a base de farelo de algodão promoveu aumento do teor de glicose com o aumento de teor proteico. Já a dieta com grão de soja cru integral promoveu redução da glicema com o aumento do teor proteico. As médias para as dietas foi de 74,12 e 72,54 mg/dL, respectivamente, semelhante a qual foi descrito por Conti (2011) porém, acima 
dos valores de referência de 40 a $60 \mathrm{mg} / \mathrm{dL}$ (FRASER, 1991). Esse teor indica que houve excesso de energia nas dietas, considerando que no presente estudo as vacas apresentaram produção média de $18 \mathrm{~kg}$ de leite/. Além disso, pela avaliação dos ácidos graxos não esterificados, foi observado que não houve efeito da dieta fornecida. A elevação de ácidos graxos não esterificados está relacionada à mobilização de reservas lipídicas quando a vaca encontra- se em balanço energético negativo.

Foi observada no presente estudo maior concentração de colesterol total e da fração HDL em vacas alimentadas com grão de soja. Estes resultados podem ter ocorrido pelo maior consumo de extrato etéreo provenientes do grão de soja integral, que possui grande quantidade de óleo.

A concentração de ureia plasmática estima a taxa de metabolização da amônia no fígado. Concentrações de ureia do sangue menores que $11 \mathrm{mg} / \mathrm{dL}$ podem indicar deficiência de PDR na dieta (BRODERICK et al., 1993), enquanto que valores acima de $19 \mathrm{mg} / \mathrm{dL}$ podem estar relacionados com excesso de PDR no rúmen, o qual é absorvido para a corrente sanguínea. As concentrações de ureia e NUS não foram afetadas pelas dietas, no entanto houve interação entre a fonte e o teor de PB utilizado na dieta. Nas dietas com farelo de algodão, vacas alimentadas com dietas com maior teor proteico (148 g de PB/kg MS) apresentaram maior concentração de nitrogênio no sangue, enquanto que vacas alimentadas com dietas com grão de soja e maior teor proteico apresentaram menor concentrações de NUS. O menor teor de NUS em vacas alimentadas com dietas a base de grão de soja com maior teor proteico (148 g de PB/kg de MS) pode ser explicados pela inibição no consumo causado por maior teor de grão de soja nas dietas com $148 \mathrm{~g}$ de PB/kg de MS.

Altas concentrações de NUS podem estar associadas com o consumo de dietas com alto teor de PDR, em associação com baixo teor de matéria orgânica fermentável no rúmen. No entanto, quantidades elevadas de PNDR, assim como de PDR, podem gerar a mesma condição, pois excessos de nitrogênio tanto de origem ruminal como pós-ruminal, são eliminados pelo mesmo processo de síntese hepática de ureia (ROSELER et al., 1993).

Vacas alimentadas com 23,4\% de PB na MS apresentaram maior concentração de ureia no sangue em relação às dietas com 19,5 e 21,4\% de PB (GHORBANI et al., 2011). A baixa concentração de ureia sanguínea resulta em maior eficiência produtiva e menor excreção de compostos nitrogenados ao ambiente. No entanto, a baixa concentração de nitrogênio pode comprometer o desempenho produtivo de vacas leiteiras (KALSCHEUR et al., 2006). No presente estudo, a concentração média de NUS $(12,78 \mathrm{mg} / \mathrm{dL})$, foi inferior aos resultados obtidos por Voltolini et al. (2008) e Souza et al. (2009), que relataram concentrações de NUS 
de 19,42 e 18,25 mg/dL, respectivamente, indicando o adequado teor de proteína das dietas.

No presente estudo, o teor de albumina não sofreu influência das dietas. A albumina plasmática está relacionada ao metabolismo proteico de longo prazo (PAYNE; PAYNE, 1987). Vacas em pico de lactação tendem a reduzir o teor de albumina no sangue, visto que a demanda de aminoácidos para a síntese do leite reduz a síntese das demais proteínas (CONTRERAS, 2000).

Os demais parâmetros sanguíneos não foram alterados pelas dietas, o que indica que vacas com produção média de $18 \mathrm{~kg} /$ dia alimentadas com cana de açúcar podem receber dietas com $130 \mathrm{~g} / \mathrm{kg}$ de PB na MS sem alterar o balanço nitrogenado.

\subsection{CONCLUSÕES}

Os parâmetros sanguíneos, frações nitrogenadas do leite e balanço de nitrogênio não são afetados pelo tipo de fonte nitrogenada principal (grão de soja cru integral ou farelo de algodão) ou pelo teor de PB da dieta (130 ou $148 \mathrm{~g}$ de PB/kg de MS). Desta forma, considerando que o uso de menor teor de PB pode significar menor custo, recomenda-se a utilização de dietas com $130 \mathrm{~g}$ de PB/kg de MS ao invés de $148 \mathrm{~g}$ de PB/kg de MS em dietas para vacas leiteiras com média de produção de $18 \mathrm{~kg} /$ dia alimentadas com dieta a base de cana de açúcar como volumoso, independentemente da fonte proteica, farelo de algodão ou grão de soja cru integral. 
CAPÍTULO 3: Fontes nitrogenadas e teor de proteína bruta em dietas com cana de açúcar para vacas em lactação: análise econômica.

\section{RESUMO}

Os objetivos deste estudo foram determinar os custos de dietas com diferentes fontes nitrogenadas e teores proteicos para vacas em lactação e determinar qual dieta promove maior margem para o produtor. Foram calculados os custos e as margens totais de dietas com cinco fontes nitrogenadas principais (ureia, farelo de soja, farelo de algodão, grão de soja cru integral e farelo de glúten de milho) e cinco teores proteicos $(13 \%, 14,5 \%, 14,8 \%, 15,7 \%$ e $16 \%)$ com cana de açúcar fornecidas para vacas em lactação. Os dados de consumo, produção e composição do leite foram obtidos a partir de 3 estudos. A análise econômica foi realizada com base nos preços médios mensais deflacionados (corrigidos do efeito da inflação) praticados no Estado de São Paulo durante o período de janeiro de 2002 a dezembro de 2012, e no cálculo dos custos de alimentação, em função das dietas e da flutuação do preço dos insumos ao longo do ano, do consumo de alimento, da produção de leite, do teor de proteína bruta no leite. Dietas com cana de açúcar com teor proteico de $14,5 \%$ com ureia como fonte nitrogenada principal apresentaram a maior margem bruta (diferença entre a receita da venda do leite e do custo da dieta) com valor médio de $\mathrm{R} \$ 1,85 \cdot \mathrm{vaca}^{-1} \cdot \mathrm{dia}^{-1}$. A dieta com $14,8 \%$ de PB com grão de soja cru integral apresentou a menor margem bruta de $\mathrm{R} \$-2,16 \cdot \mathrm{vaca}^{-1} \cdot \mathrm{dia}^{-1}$. A dieta com teor proteico de 14,5\% com ureia como fonte de nitrogênio principal apresentou-se a com maior eficiência econômica, com maior margem total, tanto no mercado convencional quanto no mercado com pagamento diferenciado pela composição do leite.

Palavras-chave: Leite. Custo de alimentação. Margem total. 


\begin{abstract}
The aims of this study was to determine the costs of diets with different protein sources and protein levels for lactating dairy cows and determine with diet promotes higher margin for producers. The costs and the gross margin were calculated for diets with five nitrogen sources (urea, soybean meal, cottonseed meal, whole raw soybean and corn gluten meal) and five protein levels $(130,145,148,157$ e 160 g/kg DM) using sugar cane as forage. Performance data were obtained from three experiments conducted previously. Economical analysis were performed based on historical prices (adjusted for the effect of inflation) in use during the period between 2002 and 2012 and based on the feed costs based on cow intake, Milk prodution and milk protein levels. The higher gross margin (difference between the income provenient milk sale and diet costs) were obtained in diets with $145 \mathrm{~g} / \mathrm{kg}$ of CP in DM with urea as main nitrogen source, with mean of $\mathrm{R} \$ 1,85 . \mathrm{cow}^{-1}$.day ${ }^{-1}$. The lower gross margin were from diet with $148 \mathrm{~g} / \mathrm{kg}$ of CP in DM with whole raw soybean as nitrogen source, with mean of $\mathrm{R} \$-2,16 \cdot \mathrm{cow}^{-1}$.day ${ }^{-1}$. The diet with protein content of $14,5 \%$ and urea as main nitrogen source had higher economic efficiency, with higher gross margin in the conventional market as in market with payment based on milk composition.
\end{abstract}

Keywords: Milk. Feed costs. Gross margin. 


\subsection{INTRODUÇÃO}

A produção de leite é uma atividade de grande importância socioeconômica para as regiões onde é desenvolvida, pois possibilita a geração de renda e empregos. Em 2012, houve aumento de 2,5\% na captação do leite totalizando 22,338 bilhões de litros. Em quinze anos o consumo de leite no Brasil aumentou de 10,7 bilhões em 1997 para 22,3 bilhões de litros em 2012 (IBGE, 2013).

Esse cenário de alterações no setor agroindustrial do leite ocorreu principalmente com as mudanças econômicas desde o início da década de 1990, que vêm exigindo rápidos ajustamentos estratégicos e estruturais. Segundo Reis et al. (2013) a desregulamentação do mercado de leite e, posteriormente, a abertura comercial da economia brasileira resultaram em um mercado competitivo em termos de qualidade, produtividade e escala de produção. No entanto, o sistema tradicional de produção de leite, em geral, é de baixa eficiência produtiva e consequentemente econômica, levando os produtores a buscar alternativas que aumentem a lucratividade da atividade.

Existem duas maneiras diretas de alterar a lucratividade de uma atividade: aumentar o preço de venda do produto final ou reduzir os custos para aumentar a margem. O aumento do preço do leite além de poder ter consequências em relação à demanda, não é ditado pelo produtor, já a redução dos custos de produção, não necessariamente depende do fator demanda. Ainda, o retorno financeiro em relação aos gastos com alimentação tem grande poder determinante dos lucros ou perdas na exploração leiteira (PEREIRA, 2000). De acordo com o Cepea (2010), a alimentação pode significar até 70\% dos custos efetivos de uma propriedade leiteira em sistema intensivo. Por outro lado, em sistemas semi-intensivos, com menores recursos técnicos essa proporção cai para $50 \%$.

A cadeia agroindustrial do leite, no âmbito da produção primário de leite, é constituída por produtores heterogêneos abrangendo os que não são especializados aos mais tecnificados, estabelecendo unidades de produção com diferentes níveis de tecnologia e produtividade. É o elo mais vulnerável da cadeia agroindustrial. O produtor é um tomador de preço por natureza, pois não controla os preços das commodities utilizados durante a produção nem o preço do produto que vende, necessitando assim administrar as variáveis possíveis como os custos de produção e eficiência técnica (ganhos em escala), para que então seu produto se torne competitivo. O aumento da eficiência produtiva é fator decisivo para a competitividade do setor leiteiro que, produzindo com menor custo, beneficiará toda a cadeia do leite (Reis et al., 
2011). Rennó et al. (2008) relataram que a eficiência econômica é influenciada pelas quantidades e custos dos nutrientes utilizados dentro de um cenário específico de produção, e não somente ao nível de produção de leite. Frente a isto, a busca por nutrientes e dietas que sejam econômicos e igualmente adequados nutricionalmente faz-se necessário.

Alguns estudos indicaram que durante o período da seca no Brasil, dentre as opções testadas de sistemas de produção de volumosos para alimentação suplementar de vacas em lactação, o fornecimento de cana de açúcar picada com ureia e enxofre, tem mostrado vantagens econômicas em comparação a outros volumosos, como capineiras, fenos e silagens (NÚSSIO et al., 2000). A adoção dessas tecnologias pelos produtores tem mudado o perfil da pecuária em muitas bacias leiteiras no Brasil, viabilizando economicamente a atividade, com competitividade e sustentabilidade da atividade leiteira.

A proteína é um nutriente limitante em dietas para ruminantes e um dos ingredientes mais dispendiosos devido ao seu alto requerimento e elevado custo em relação aos demais ingredientes. Deste modo, o uso de fontes proteicas alternativas pode otimizar os resultados produtivos por maior eficiência de uso de nutrientes e consequentemente pela redução de custos de produção, o que proporciona melhor adequação de nutrientes disponíveis às necessidades metabólicas do animal (PINA et al., 2006b).

Atualmente, várias fontes proteicas podem ser utilizadas na nutrição de ruminantes, cujo maior destaque é a soja, comercializada principalmente na forma de farelo. Entretanto, devido à sua forte dependência de preço no mercado internacional, fontes alternativas vêm sendo estudadas para substituir o farelo de soja. Sampaio, Oliveira e Tosi (1995) sugeriram o grão de soja, oferecendo vantagem econômica em relação aos suplementos formulados com o farelo (ALBRO; WEBER; DELCURTO, 1993), uma vez que tem alta disponibilidade, custo viável por não necessitar qualquer tipo de processamento. O farelo de algodão pode ser utilizado para substituir o farelo de soja, embora apresente menores teores de energia e proteína, visando à obtenção de dietas mais baratas, uma vez que pode reduzir o custo do concentrado e viabilizar dietas com cana de açúcar como volumoso. No entanto, apresenta menores teores de energia e proteína e é caracterizado pelo maior teor de proteína não degradável no rúmen (NRC, 2001; SOUZA et al., 2009).

$\mathrm{Na}$ composição do custo de alimentação, não só os alimentos concentrados, mas também os volumosos têm uma participação importante, pois representam de 40 a $80 \%$ da matéria seca (MS) da dieta das várias categorias que compõem o rebanho leiteiro. Além disso, é a qualidade do volumoso que determinará variações na quantidade e qualidade da ração concentrada. 
Dentre as opções de volumosos suplementares, a cana de açúcar tem posição consolidada. Simulações comparando diferentes fontes de forragem para o rebanho, frequentemente sugerem a cana de açúcar como uma das alternativas que reúne condições mais interessantes. Poucas plantas forrageiras receberam atenção especial como a cana, que foi estudada amplamente, havendo grande investimento em pesquisas direcionadas à cultura e nutrição de animais com vistas à formulação de rações contendo essa forragem (SCHIMIDT; NUSSIO, 2005).

No Brasil, uma alternativa para o período de menor oferta de pastagens é a cana de açúcar com suplementação com mistura de ureia e sulfato de amônio. A ureia é um composto nitrogenado não proteico (NNP) que pode ser utilizado como fonte de nitrogênio para formação de proteína microbiana, uma vez que comparada com outras fontes de nitrogênio é mais barata e se utilizada de forma adequada com uma dieta balanceada pode manter a produtividade do rebanho (GUIMARÃES JUNIOR et al., 2007).

Dessa forma, esse trabalho foi realizado com o objetivo de verificar o desempenho e a viabilidade econômica do uso de diferentes níveis de concentrados com diferentes fontes proteicas na dieta de vacas leiteiras alimentadas com cana de açúcar como fonte de volumoso.

A hipótese deste estudo é que as variações sazonais dos preços dos insumos podem alterar o custo das dietas. Além disso, dietas com diferentes teores e fontes proteicas podem influenciar a produção composição do leite e consumo de alimento impactando nas margens médias e totais.

\subsection{MATERIAL E MÉTODOS}

Este estudo foi realizado em duas etapas. A primeira etapa foi desenvolvida no setor de Bovinocultura de Leite da Prefeitura do Campus Administrativo de Pirassununga-SP (PCAPS), da Universidade de São Paulo, e consistiu na coleta de dados zootécnicos de três experimentos realizados a campo com a finalidade de avaliar respostas metabólicas e produtivas de vacas em lactação alimentadas com diferentes dietas proteicas contendo diferentes fontes e teores de PB. A fonte volumosa utilizada nos três experimentos foi a cana de açúcar picada na proporção 45:55 volumoso:concentrado e o delineamento experimental dos três experimentos foi quadrado latino $4 \times 4$ com quatro tratamentos cada um, totalizando 12 dietas avaliadas.

O experimento1 utilizou 12 vacas da raça Holandesa com peso vivo médio (PVM) de 
$580 \mathrm{~kg}$, em estágio médio de lactação (110 dias) e produção média de $19,1 \mathrm{~kg} \cdot \mathrm{vaca}^{-1} \cdot \mathrm{dia}^{-1}$; recebendo as dietas: Controle (farelo de soja e ureia, 15,7\% PB); Alta degradabilidade (farelo de soja e ureia com concentração de 1,7\% na MS, 15,7\% PB); Média degradabilidade (grão de soja cru, 15,7\% PB); e Baixa degradabilidade (farelo de glúten de milho, 15,7\% PB). As composições das dietas encontram-se na tabela 7.

Tabela 7 - Proporção de ingredientes utilizados nas dietas experimentais utilizadas no experimento 1

\begin{tabular}{|c|c|c|c|c|}
\hline \multirow[b]{2}{*}{ Ingredientes } & \multicolumn{4}{|c|}{ Dietas } \\
\hline & Controle $^{1}$ & Alta $^{2}$ & Média $^{3}$ & Baixa $^{4}$ \\
\hline & \multicolumn{4}{|c|}{$g / K g$} \\
\hline Milho fubá & 0,3039 & 0,3352 & 0,2401 & 0,3029 \\
\hline Farelo de soja $48 \%$ PB & 0,164 & 0,1199 & 0,0642 & 0,1227 \\
\hline Soja grão integral in natura & 0,000 & 0,000 & 0,1600 & 0,0000 \\
\hline Glúten de milho & 0,000 & 0,000 & 0,000 & 0,0267 \\
\hline Ureia & 0,0102 & 0,0171 & 0,0075 & 0,0102 \\
\hline Sulfato de amônia & 0,001 & 0,001 & 0,001 & 0,0005 \\
\hline Bicarbonato de sódio & 0,0075 & 0,0075 & 0,0075 & 0,0069 \\
\hline Óxido de magnésio & 0,0027 & 0,0027 & 0,0027 & 0,0027 \\
\hline Sal mineral & 0,0347 & 0,0348 & 0,0348 & 0,0348 \\
\hline Calcário & 0,0037 & 0,0037 & 0,0037 & 0,0037 \\
\hline Sal comum & 0,0027 & 0,0027 & 0,0027 & 0,0027 \\
\hline Cana de açúcar & 0,4695 & 0,4753 & 0,4757 & 0,4792 \\
\hline Total & 1,00 & 1,00 & 1,00 & 0,99 \\
\hline
\end{tabular}

${ }^{\mathrm{T}}$ Dieta com $15,7 \%$ de PB com farelo de soja e ureia como fontes nitrogenadas; ${ }^{2}$ Dieta com $15,7 \%$ de PB com farelo de soja e ureia como fontes nitrogenadas em $1,7 \%$ da MS; ${ }^{3}$ Dieta com $15,7 \%$ de PB com grão de soja cru integral como fonte proteica; ${ }^{4}$ Dieta com $15,7 \%$ de PB com farelo de glúten de milho como fonte proteica.

Fonte: adaptado de Naves, 2010.

O experimento 2 utilizou 12 vacas da raça Holandesa com PVM de 611 kg, com 235 dias de lactação e com produção de leite média de $20 \mathrm{~kg} \cdot \mathrm{vaca}^{-1} \cdot \mathrm{dia}^{-1}$; recebendo dietas com duas opções de fonte e teores proteicas: Farelo de soja, 14,5\% PB; Farelo de soja, 16\% PB; Ureia, 14,5\% PB; e Ureia, $16 \%$ PB. As composições das dietas encontram-se na tabela 8. 
Tabela 8 - Proporção de ingredientes utilizados nas dietas experimentais utilizadas no experimento 2

\begin{tabular}{|c|c|c|c|c|}
\hline \multirow{3}{*}{ Ingredientes } & \multicolumn{4}{|c|}{ Dietas } \\
\hline & \multicolumn{2}{|c|}{ Farelo de Soja } & \multicolumn{2}{|c|}{ Ureia } \\
\hline & $16 \%{ }^{1}$ & $14,5 \%^{2}$ & $16 \%^{3}$ & $14,5 \%^{4}$ \\
\hline & \multicolumn{4}{|c|}{$g / K g$} \\
\hline Milho fubá & 0,2318 & 0,2679 & 0,2749 & 0,3167 \\
\hline Farelo de soja $48 \%$ PB & 0,1514 & 0,1098 & 0,0798 & 0,0549 \\
\hline Soja grão integral in natura & 0,1198 & 0,1259 & 0,1397 & 0,1231 \\
\hline Ureia & 0,0022 & 0,0022 & 0,0100 & 0,0100 \\
\hline Sulfato de amônia & 0,0000 & 0,0000 & 0,0011 & 0,0011 \\
\hline Bicarbonato de sódio & 0,0078 & 0,0078 & 0,0078 & 0,0078 \\
\hline Óxido de magnésio & 0,0028 & 0,0028 & 0,0028 & 0,0028 \\
\hline Sal mineral & 0,0300 & 0,0300 & 0,0299 & 0,0300 \\
\hline Calcário & 0,0011 & 0,0011 & 0,0011 & 0,0011 \\
\hline Sal comum & 0,0028 & 0,0028 & 0,0028 & 0,0028 \\
\hline Cana de açúcar & 0,4504 & 0,4498 & 0,4501 & 0,4498 \\
\hline TOTAL & 1,00 & 1,00 & 1,00 & 1,00 \\
\hline
\end{tabular}

O experimento 3 utilizou 12 vacas da raça Holandesa com peso vivo médio de $550 \mathrm{~kg}$, em estágio intermediário de lactação (entre 90 e 220 dias de lactação), 19 kg.vaca ${ }^{-1} \cdot$ dia $^{-1}$; recebendo dietas com duas opções de fonte e teores proteicas: Grão de soja cru integral, 13\% PB; Grão de soja cru integral, 14,8\% PB; Farelo de algodão 38\%, 13\% PB; Farelo de algodão $38 \%, 14,8 \%$ PB. (Tabela 9). 
Tabela 9 - Proporção dos ingredientes utilizados nas dietas experimentais utilizadas no experimento 3

\begin{tabular}{|c|c|c|c|c|}
\hline \multirow{3}{*}{ Ingredientes } & \multicolumn{4}{|c|}{ Dietas } \\
\hline & \multicolumn{2}{|c|}{ Grão de soja } & \multicolumn{2}{|c|}{ Farelo de algodão } \\
\hline & $13 \%^{1}$ & $14,8 \%^{2}$ & $13 \%^{3}$ & $14,8 \%^{4}$ \\
\hline & \multicolumn{4}{|c|}{$g / K g$} \\
\hline Milho fubá & 0,340 & 0,299 & 0,341 & 0,304 \\
\hline Farelo de soja $48 \%$ PB & 0,030 & 0,050 & 0,030 & 0,050 \\
\hline Grão soja & 0,120 & 0,140 & - & - \\
\hline Farelo de algodão $30 \%$ PB & - & - & 0,114 & 0,135 \\
\hline Ureia & 0,008 & 0,009 & 0,008 & 0,009 \\
\hline Sulfato de amônia & 0,002 & 0,002 & 0,002 & 0,002 \\
\hline Sal mineral & 0,020 & 0,020 & 0,002 & 0,002 \\
\hline Bicarbonato de sódio & 0,008 & 0,008 & 0,008 & 0,008 \\
\hline Óxido de magnésio & 0,002 & 0,002 & 0,002 & 0,002 \\
\hline Fosfato bicálcico & 0,008 & 0,008 & 0,008 & 0,008 \\
\hline Calcário & 0,006 & 0,006 & 0,006 & 0,006 \\
\hline Cloreto de potássio & 0,003 & 0,003 & 0,003 & 0,003 \\
\hline Sal comum & 0,002 & 0,002 & 0,003 & 0,004 \\
\hline Cana de açúcar & 0,450 & 0,450 & 0,450 & 0,450 \\
\hline TOTAL & 1,00 & 1,00 & 0,98 & 0,99 \\
\hline
\end{tabular}

${ }^{1}$ Dieta com $13 \%$ de PB com grão de soja cru integral como fonte proteica; ${ }^{2}$ Dieta com $14,8 \%$ de PB com grão de soja cru integral como fonte proteica; ${ }^{3}$ Dieta com $13 \%$ de PB com farelo de algodão como fonte proteica;

${ }^{4}$ Dieta com $14,8 \%$ de PB com farelo de algodão como fonte proteica.

Fonte: Dados da pesquisa.

A segunda etapa desse trabalho se deu com a compilação dos resultados obtidos nos experimentos relativos ao consumo de matéria natural diário, produção de leite diária e teor de proteína média por litro de leite (Tabela 10), e posterior realização da análise econômicofinanceira dos referidos sistemas alimentares. 
Tabela 10 - Dados de consumo de ração, produção de leite e teor de proteína bruta média no leite de acordo com cada dieta experimental nos três experimentos estudados

\begin{tabular}{lcccc}
\hline \multicolumn{1}{c}{$\begin{array}{c}\text { Experimento 1 } \\
\text { Variável }\end{array}$} & Controle $^{\mathbf{1}}$ & Alta $^{\mathbf{2}}$ & Média $^{\mathbf{3}}$ & Baixa $^{\mathbf{4}}$ \\
\hline Consumo $\left(\mathrm{kg} \cdot \mathrm{MN}^{-1} \cdot \mathrm{dia}^{-1}\right)$ & 43,39 & 43,48 & 43,00 & 43,20 \\
Produçãa leite $\left(\mathrm{kg} \cdot \mathrm{dia}^{-1}\right)$ & 17,24 & 17,32 & 16,15 & 17,53 \\
Proteína $\left(\mathrm{kg} \cdot \mathrm{dia}^{-1}\right)$ & 0,57 & 0,55 & 0,52 & 0,57 \\
Proteína (\%) & 3,47 & 3,24 & 3,33 & 3,28 \\
\hline
\end{tabular}

Experimento 2

Dietas

\begin{tabular}{|c|c|c|c|c|}
\hline \multirow{2}{*}{ Variável } & \multicolumn{2}{|c|}{ Farelo de Soja } & \multicolumn{2}{|c|}{ Ureia } \\
\hline & $16 \%^{5}$ & $14,5 \%^{6}$ & $16 \%^{7}$ & $14,5 \%^{8}$ \\
\hline Consumo $\left(\mathrm{kg} \cdot \mathrm{MN}^{-1} \cdot \mathrm{dia}^{-1}\right)$ & 44,38 & 43,85 & 43,91 & 42,23 \\
\hline Produção leite $\left(\mathrm{kg} \cdot \operatorname{dia}^{-1}\right)$ & 20,23 & 19,65 & 17,04 & 19,71 \\
\hline Proteína (kg.dia $\left.{ }^{-1}\right)$ & 0,66 & 0,65 & 0,55 & 0,63 \\
\hline Proteína (\%) & 3,38 & 3,38 & 3,28 & 3,34 \\
\hline
\end{tabular}

Experimento 3

Dietas

\begin{tabular}{|c|c|c|c|c|}
\hline \multirow{2}{*}{ Variável } & \multicolumn{2}{|c|}{ Grão de soja } & \multicolumn{2}{|c|}{ Farelo de algodão } \\
\hline & $13 \%^{9}$ & $14,8 \%^{10}$ & $13 \%^{11}$ & $14,8 \%^{12}$ \\
\hline Consumo $\left(\mathrm{kg} \cdot \mathrm{MN}^{-1} \cdot \mathrm{dia}^{-1}\right)$ & 43,4 & 41,03 & 41,56 & 42,87 \\
\hline Produção leite $\left(\mathrm{kg}\right.$ dia $\left.^{-1}\right)$ & 16,47 & 15,37 & 16,62 & 16,53 \\
\hline Proteína (kg.dia $\left.{ }^{-1}\right)$ & 0,54 & 0,50 & 0,55 & 0,56 \\
\hline Proteína (\%) & 3,29 & 3,28 & 3,30 & 3,40 \\
\hline
\end{tabular}

${ }^{1}$ Dieta com $15,7 \%$ de PB com farelo de soja e ureia como fontes nitrogenadas; ${ }^{2}$ Dieta com $15,7 \%$ de PB com farelo de soja e ureia como fontes nitrogenadas em $1,7 \%$ da MS ${ }^{3}$ Dieta com 15,7\% de PB com grão de soja cru integral como fonte proteica; ${ }^{4}$ Dieta com $15,7 \%$ de PB com farelo de glúten de milho como fonte proteica; ${ }^{5}$ Dieta com $16 \%$ de PB com farelo de soja como fonte proteica; ${ }^{6}$ Dieta com 14,5 de PB com farelo de soja como fonte proteica; ${ }^{7}$ Dieta com $16 \%$ de PB com ureia como fonte nitrogenada; ${ }^{8}$ Dieta com $14,5 \%$ de PB com ureia como fonte nitrogenada; ${ }^{9}$ Dieta com $13 \%$ de PB com grão de soja cru integral como fonte proteica; ${ }^{10}$ Dieta com $14,8 \%$ de PB com grão de soja cru integral como fonte proteica; ${ }^{11}$ Dieta com $13 \%$ de PB com farelo de algodão como fonte proteica; ${ }^{12}$ Dieta com $14,8 \%$ de PB com farelo de algodão como fonte proteica.

Fonte: Adaptado de Naves (2010), Conti (2011) e Migliano (2013).

A partir desses coeficientes técnicos desenvolveu-se a análise econômico-financeira. Enfoques de curto prazo foram contemplados. As análises de curto prazo compreenderam o cálculo da margem média (MME) e da margem total (MT).

Todos os preços utilizados nos cálculos foram os médios mensais praticados no Estado de São Paulo entre os anos de 2002 a 2012, obtidos por consulta ao banco de dados de preços pagos pelos produtores, do Instituto de Economia Agrícola (IEA) e do Centro de Estudos Avançados em Economia Aplicada (CEPEA). Os preços de venda do litro de leite foram estabelecidos também com base no banco de dados do IEA (preços pagos aos produtores). Todos os valores foram deflacionados para o mês de janeiro de 2012 utilizando o Índice Nacional de Preços ao Consumidor (INPC) (IBGE/INPC, 2012).

Com os preços dos insumos necessários para as 12 dietas estabelecidas, calculou-se o 
custo das dietas por $\mathrm{kg}(\mathrm{Cd})$. Com o custo da dieta por $\mathrm{kg}$, estabeleceu-se o custo da dieta por vaca por dia $(\mathrm{Cvd})$, o custo da dieta por litro de leite produzido $(\mathrm{Cl})$, e o custo para cada ponto percentual de $\mathrm{PB}$ no leite $(\mathrm{Cpb})$, sendo:

$$
\text { Cvd }=\text { Cd x Consumo diário }
$$

onde,

Cvd: custo da dieta por vaca por dia;

Cd: custo da dieta;

Consumo diário: média do consumo diário por vaca.

$$
\mathrm{Cl}=\mathrm{Cvd} / \mathrm{l}
$$

onde,

$\mathrm{Cl}$ : custo da dieta por litro de leite produzido;

Cvd: custo da dieta por vaca por dia;

$l$ : média diária de litros de leite produzido por vaca.

$$
\mathrm{Cpb}=\mathrm{Cvd} / \% \mathrm{PBl}
$$

onde,

Cpb: custo por cada ponto percentual de PB no leite;

Cvd: custo da dieta por vaca por dia;

\% PBl: porcentagem média de PB no litro de leite produzido.

Com os custos de $\mathrm{Cd}, \mathrm{Cvd}, \mathrm{Cl}$ e $\mathrm{Cpb}$ pode-se calcular as margens médias e totais, que foram:

$$
\mathrm{MMe}=\mathrm{Pl}-\mathrm{Cl}
$$

onde,

Pl: preço pago pelo litro do leite ao produtor;

$\mathrm{Cl}$ : custo da dieta por litro de leite produzido;

$$
\mathrm{MT}=\mathrm{R}-\mathrm{Cvd}
$$

onde,

$\mathrm{R}$ : receita obtida com a venda do leite;

Cvd: custo da dieta por vaca por dia. 
Para cálculo das margens brutas baseadas em pagamento por qualidade, foi considerado o teor de proteína bruta do leite com os preços praticados por uma cooperativa do estado de São Paulo no período do ano de 2011. O cálculo dos custos e margens permitiu a análise econômico-financeira da produção de leite em função das dietas e da flutuação do preço dos insumos ao longo do ano. Os resultados foram submetidos análise estatística pelo programa SAS (Version 9.1.3, SAS Institute, Cary, NC, 2004), verificando a normalidade dos resíduos e a homogeneidade das variâncias pelo Proc GLM. Os dados foram analisados de acordo com as médias anuais obtidas de cada dieta, pelo comando Proc MIXED do SAS, adotando-se nível de significância de $5 \%(\mathrm{p}<0,05)$ pelo teste Duncan.

\subsection{RESULTADOS E DISCUSSÃO}

Os custos e as margens médias e totais calculados para as 12 dietas encontram-se na tabelas 11 e 12 . 
Tabela 11 - Produção de leite e custos médios das dietas por quilo, por vaca, por litro de leite e por porcentagem de proteína bruta no leite, margens médias e totais das dietas.

\begin{tabular}{|c|c|c|c|c|c|c|c|c|}
\hline Dietas & $\begin{array}{c}\text { Produção } \\
\text { (litro/ vaca } \\
{ }^{1} \cdot \text { dia }^{-1}\end{array}$ & $\begin{array}{c}\text { Custo } \\
\text { dieta } \\
(\mathrm{R} \$ / \mathrm{kg})\end{array}$ & $\begin{array}{c}\text { Custo } \\
\text { dieta } \\
\left(\mathrm{R} \$ / \mathrm{vaca}^{-}\right. \\
\left.1 . \mathrm{dia}^{-1}\right)\end{array}$ & $\begin{array}{c}\text { Custo } \\
\text { dieta } \\
\text { ( } \mathrm{R} \$ / \text { litro) }\end{array}$ & $\begin{array}{c}\text { Custo } \\
\text { dieta } \\
(\mathrm{R} \$ / \% \mathrm{~PB} \\
\text { no leite) }\end{array}$ & $\begin{array}{l}\text { Margem } \\
\text { Média } \\
\text { (R\$/litro) }\end{array}$ & $\begin{array}{c}\text { Margem } \\
\text { Total } \\
\left(\mathrm{R} \$ / \mathrm{vaca}^{-}\right. \\
\left.1 . \mathrm{dia}^{-1}\right)\end{array}$ & $\begin{array}{c}\text { Margem } \\
\text { Total } \\
(\mathrm{R} \$ / \% \mathrm{~PB} \\
\text { no leite por } \\
\text { vaca }^{-1} . \\
\left.\mathrm{dia}^{-1}\right)\end{array}$ \\
\hline $13 \mathrm{FA}$ & 16,62 & 0,3343 & 13,8917 & 0,8358 & 4,2096 & 0,0402 & 0,6684 & 1,117 \\
\hline $13 \mathrm{GS}$ & 16,47 & 0,3626 & 15,7378 & 0,9555 & 4,7835 & $-0,0795$ & $-1,3090$ & $-1,013$ \\
\hline $14,5 \mathrm{FS}$ & 19,65 & 0,3814 & 16,7270 & 0,8512 & 4,9488 & 0,0248 & 0,4877 & 1,018 \\
\hline $14,5 \mathrm{U}$ & 19,71 & 0,3650 & 15,4131 & 0,7820 & 4,6147 & 0,0941 & 1,8541 & 2,386 \\
\hline $14,8 \mathrm{FA}$ & 16,53 & 0,3500 & 15,0048 & 0,9077 & 4,4132 & $-0,0317$ & $-0,5235$ & 0,072 \\
\hline $14,8 \mathrm{GS}$ & 15,37 & 0,3807 & 15,6220 & 1,0164 & 4,7628 & $-0,1403$ & $-2,1569$ & $-1,880$ \\
\hline $16 \mathrm{FS}$ & 20,23 & 0,3897 & 17,2932 & 0,8548 & 5,1163 & 0,0212 & 0,4295 & 0,976 \\
\hline $16 \mathrm{U}$ & 17,04 & 0,3738 & 16,4127 & 0,9632 & 5,0039 & $-0,0871$ & $-1,4846$ & $-1,178$ \\
\hline Alta & 17,32 & 0,3511 & 15,2686 & 0,8816 & 4,7125 & $-0,0055$ & $-0,0952$ & 0,217 \\
\hline Baixa & 17,53 & 0,3561 & 15,5733 & 0,9643 & 4,6767 & $-0,0882$ & $-1,4248$ & 0,293 \\
\hline Controle & 17,24 & 0,3591 & 15,3797 & 0,8773 & 4,6889 & $-0,0013$ & $-0,0223$ & 0,140 \\
\hline Média & 16,15 & 0,3621 & 15,5843 & 0,9040 & 4,4912 & $-0,0279$ & $-0,4810$ & $-0,989$ \\
\hline
\end{tabular}

${ }^{1}$ Dieta com $13 \%$ de PB com farelo de algodão como fonte proteica; ${ }^{2}$ Dieta com $13 \%$ de PB com grão de soja cru integral como fonte proteica; ${ }^{3}$ Dieta com 14,5 de PB com farelo de soja como fonte proteica; ${ }^{4}$ Dieta com $14,5 \%$ de PB com ureia como fonte nitrogenada; ${ }^{5}$ Dieta com $14,8 \%$ de PB com farelo de algodão como fonte proteica; ${ }^{6}$ Dieta com $14,8 \%$ de PB com grão de soja cru integral como fonte proteica; ${ }^{7}$ Dieta com $16 \%$ de PB com farelo de soja como fonte proteica; ${ }^{8}$ Dieta com $16 \%$ de PB com ureia como fonte nitrogenada; ${ }^{9}$ Dieta com $15,7 \%$ de PB com farelo de soja e ureia como fontes nitrogenadas; ${ }^{10}$ Dieta com $15,7 \%$ de PB com farelo de soja e ureia como fontes nitrogenadas em $1,7 \%$ da MS; ${ }^{11}$ Dieta com $15,7 \%$ de PB com grão de soja cru integral como fonte proteica; ${ }^{12}$ Dieta com 15,7\% de PB com farelo de glúten de milho como fonte proteica; ${ }^{13}$ Relação entre o preço do litro de leite e o custo de produção do litro de leite; ${ }^{14}$ Relação entre a receita por vaca e o custo por vaca. 
Tabela 12 - Médias mensais e média anual das margens totais em função das dietas.

\begin{tabular}{ccccccccccccccc}
\hline & JAN & FEV & MAR & ABR & MAI & JUN & JUL & AGO & SET & OUT & NOV & DEZ & Médias $^{13}$ & EPM $^{14}$ \\
\hline $13 \mathrm{FA}^{1}$ & $-0,5590$ & $-0,2621$ & $-0,2013$ & 0,5245 & 1,2176 & 1,3453 & 1,5645 & 1,7801 & 1,3310 & 0,9590 & 0,5190 & $-0,1972$ & $0,6684^{\mathrm{a}}$ & 0,2343 \\
$13 \mathrm{GS}^{2}$ & $-2,4752$ & $-2,0409$ & $-1,9038$ & $-1,1522$ & $-0,6406$ & $-0,5080$ & $-0,4039$ & $-0,2883$ & $-0,9020$ & $-1,3119$ & $-1,6849$ & $-2,3967$ & $-1,3090^{\mathrm{b}}$ & 0,2257 \\
$14,5 \mathrm{FS}^{3}$ & $-0,7516$ & $-0,3977$ & $-0,1212$ & 0,6951 & 1,2185 & 1,3667 & 1,4427 & 1,6198 & 0,9553 & 0,4931 & 0,0257 & $-0,6944$ & $0,4877^{\mathrm{c}}$ & 0,2471 \\
$14,5 \mathrm{U}^{4}$ & 0,5478 & 0,9193 & 1,1314 & 1,9468 & 2,5135 & 2,6959 & 2,8453 & 3,0189 & 2,3987 & 1,9701 & 1,5078 & 0,7533 & $1,8541^{\mathrm{d}}$ & 0,2500 \\
$14,8 \mathrm{FA}^{5}$ & $-1,6974$ & $-1,4368$ & $-1,3330$ & $-0,6214$ & 0,0741 & 0,1677 & 0,3467 & 0,5786 & 0,1146 & $-0,2858$ & $-0,7483$ & $-1,4408$ & $-0,5235^{\mathrm{e}}$ & 0,2310 \\
$14,8 \mathrm{GS}^{6}$ & $-3,1732$ & $-2,7970$ & $-2,6178$ & $-1,9284$ & $-1,4880$ & $-1,3882$ & $-1,3417$ & $-1,2340$ & $-1,8364$ & $-2,2441$ & $-2,6010$ & $-3,2329$ & $-2,1569^{\mathrm{f}}$ & 0,2082 \\
$16 \mathrm{FS}^{7}$ & $-0,8299$ & $-0,5189$ & $-0,0597$ & 0,7673 & 1,2400 & 1,3453 & 1,2926 & 1,5495 & 0,8607 & 0,3660 & $-0,0984$ & $-0,7603$ & $0,4295^{\mathrm{c}}$ & 0,2497 \\
$16 \mathrm{U}^{8}$ & $-2,6246$ & $-2,2469$ & $-1,9282$ & $-1,1477$ & $-0,7094$ & $-0,6290$ & $-0,6780$ & $-0,4941$ & $-1,1531$ & $-1,6006$ & $-1,9882$ & $-2,6157$ & $-1,4846^{\mathrm{g}}$ & 0,2273 \\
Alta $^{9}$ & $-1,3742$ & $-0,9919$ & $-0,7844$ & 0,0724 & 0,5453 & 0,6805 & 0,7448 & 0,9584 & 0,4281 & 0,0336 & $-0,3787$ & $-1,0767$ & $-0,0952^{\mathrm{h}}$ & 0,2318 \\
Média $^{10}$ & $-2,4129$ & $-2,0850$ & $-1,8569$ & $-1,1504$ & $-0,7246$ & $-0,6322$ & $-0,6198$ & $-0,5045$ & $-1,1311$ & $-1,5454$ & $-1,9209$ & $-2,5143$ & $-1,4248^{\mathrm{g}}$ & 0,2102 \\
Baixa $^{11}$ & $-1,3037$ & $-0,9715$ & $-0,6426$ & 0,1735 & 0,6522 & 0,7950 & 0,8619 & 1,1031 & 0,4065 & 0,0331 & $-0,3510$ & $-1,0236$ & $-0,0223^{\mathrm{h}}$ & 0,2366 \\
Controle $^{12}$ & $-1,7401$ & $-1,3817$ & $-1,0562$ & $-0,2110$ & 0,2181 & 0,3158 & 0,2828 & 0,5394 & $-0,0136$ & $-0,4283$ & $-0,8263$ & $-1,4709$ & $-0,4810^{\mathrm{e}}$ & 0,2283 \\
\hline
\end{tabular}

${ }^{1}$ Dieta com 13\% de PB com farelo de algodão como fonte proteica; ${ }^{2}$ Dieta com $13 \%$ de PB com grão de soja cru integral como fonte proteica; ${ }^{3}$ Dieta com 14,5 de PB com farelo de soja como fonte proteica; ${ }^{4}$ Dieta com $14,5 \%$ de PB com ureia como fonte nitrogenada; ${ }^{5}$ Dieta com $14,8 \%$ de PB com farelo de algodão como fonte proteica; ${ }^{6}$ Dieta com $14,8 \%$ de PB com grão de soja cru integral como fonte proteica; ${ }^{7}$ Dieta com $16 \%$ de PB com farelo de soja como fonte proteica; ${ }^{8}$ Dieta com $16 \%$ de PB com ureia como fonte nitrogenada; ${ }^{9}$ Dieta com $15,7 \%$ de PB com farelo de soja e ureia como fontes nitrogenadas; ${ }^{10}$ Dieta com $15,7 \%$ de PB com farelo de soja e ureia como fontes nitrogenadas em 1,7\% da MS; ${ }^{11}$ Dieta com 15,7\% de PB com grão de soja cru integral como fonte proteica; ${ }^{12}$ Dieta com $15,7 \%$ de PB com farelo de glúten de milho como fonte proteica; ${ }^{13}$ Médias anuais de acordo com as dietas. ${ }^{14}$ Erro padrão da média.

*Letras diferentes na mesma coluna diferem estatisticamente $(\mathrm{P}<0,05)$. 
Dentro das dietas formuladas a que apresentou maior margem total em relação à produção total de leite e composição foi a dieta com 14,5\% de PB com ureia como fonte nitrogenada (Figura 7). A margem total média para esta dieta foi de $\mathrm{R} \$ 1,85$, sendo o valor máximo de $\mathrm{R} \$ 3,02$ no mês de agosto. O preço da ureia varia 10,49\% ao longo do ano com valor mínimo de $\mathrm{R} \$ 2,38 / \mathrm{Kg}$ e máximo de $\mathrm{R} \$ 2,63 / \mathrm{Kg}$ (Figura 8). Essa flutuação de preços de acordo com o mês explica esta diferença entre as margens totais quando analisada a dieta com ureia isoladamente.

Figura 7 - Curvas das margens totais (margem total sobre a produção de uma vaca) mensais das dietas

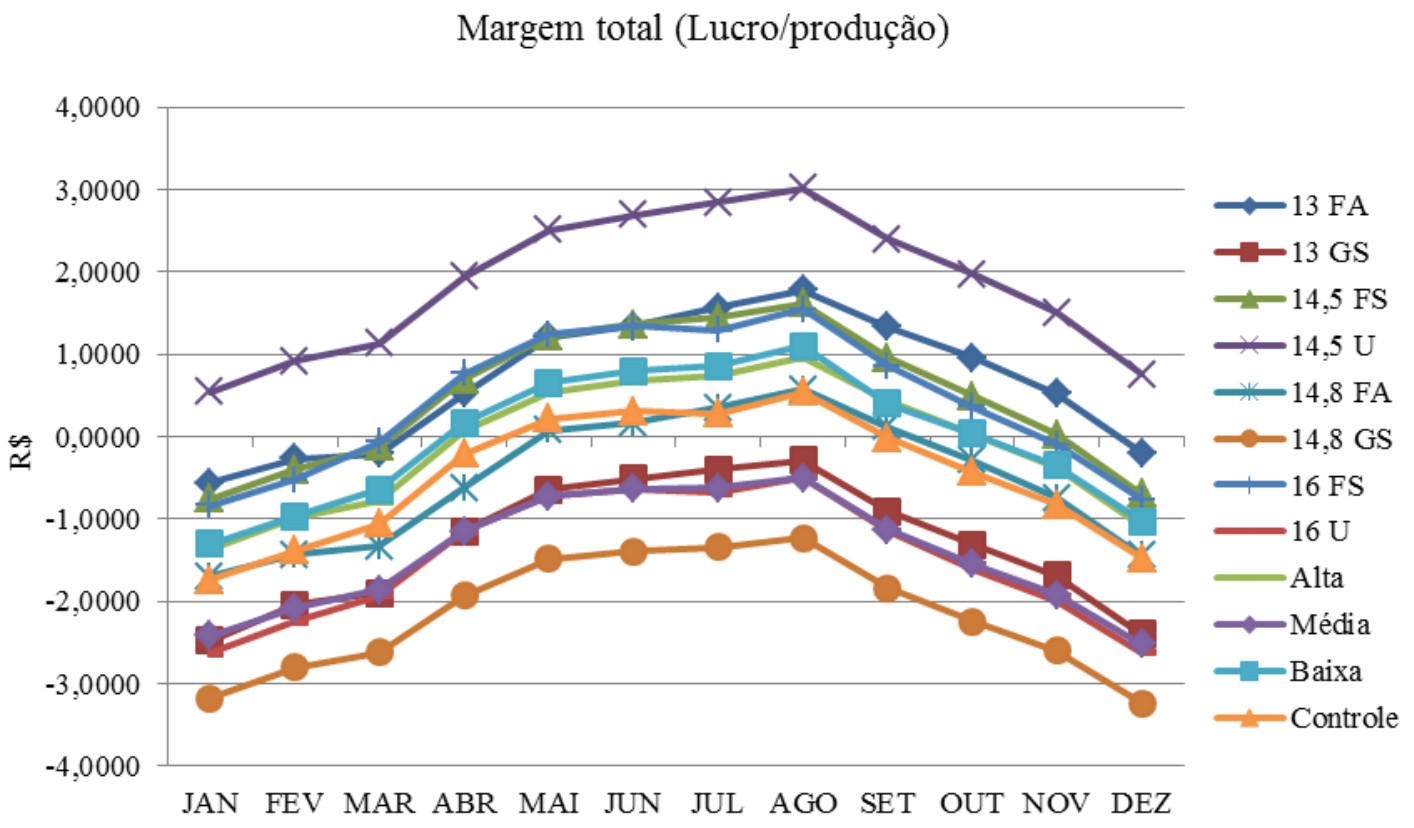


Figura 8 - Gráfico da série histórica (2002-2012) dos preços médios mensais da ureia pecuária ao longo do ano

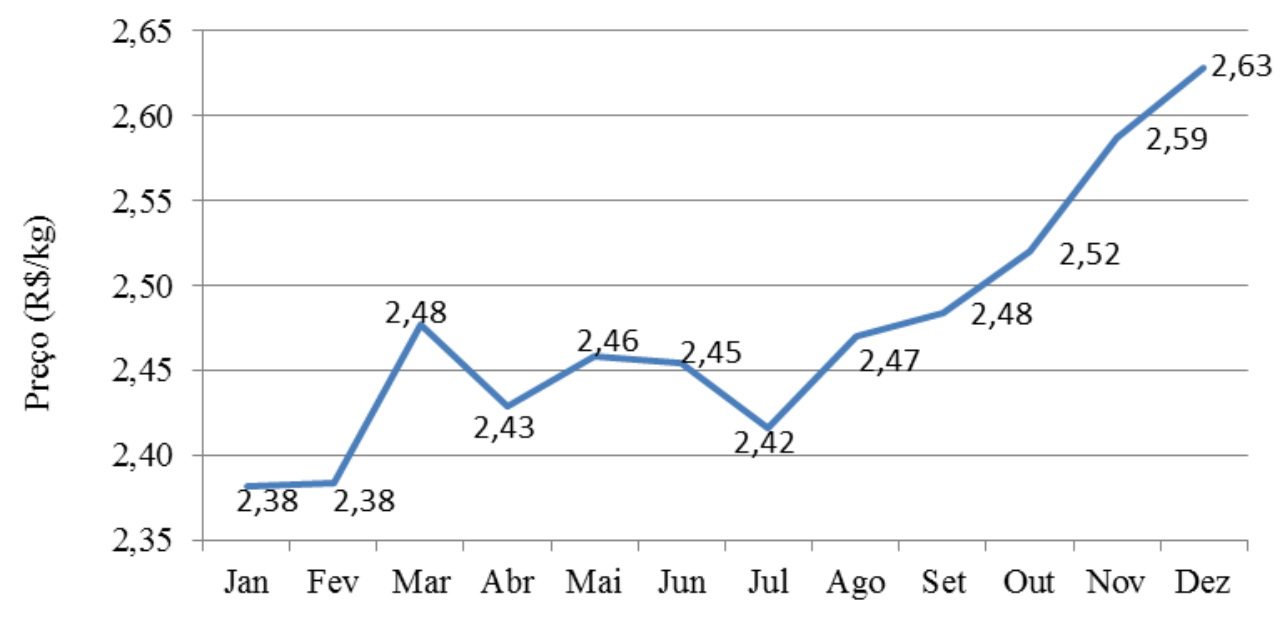

A oferta da cana de açúcar, principalmente no período de seca, é fator determinante para a utilização como volumoso. A variação do preço da cana é claramente sazonal, de acordo com a safra e entressafra, compreendida entre abril e novembro (Figura 9) com variação anual de 17,28\%, com preço mínimo de $\mathrm{R} \$ 52,32$ e máximo de $\mathrm{R} \$ 63,25$.

Apesar de o preço da tonelada de cana de açúcar estar superior no mês de agosto, os resultados apresentam-se favoráveis para este período, pois no mesmo período os demais ingredientes da dieta estão em período de safra, reduzindo o custo do concentrado e tornando interessante a utilização da cana de açúcar como volumoso e ureia como fonte nitrogenada principal. Mesmo com o preço do quilo de ureia ser significativo, a baixa inclusão deste ingrediente não contribui significativamente na composição do custo $(1,33 \%)$ quando comparado aos demais ingredientes como o grão de soja cru $(27,22 \%$ e $30,15 \%)$ ou farelo de soja $(36,31 \%$ e $18,71 \%)$ e farelo de algodão $(8,57 \%$ e $5,45 \%)$. Nas dietas que utilizaram de ureia como fonte nitrogenada principal, a inclusão foi de 0,02 $\mathrm{kg} / \mathrm{vaca}$ para teor proteico de $14,5 \%$ com o custo médio de $\mathrm{R} \$ 0,048 / \mathrm{kg}$ de dieta e $0,01 \mathrm{~kg}$ para a dieta com teor proteico de $16 \%$ com custo médio de $\mathrm{R} \$ 0,024 / \mathrm{kg}$ de dieta. Os preços médios das dietas totais foram de $\mathrm{R} \$ 0,37$ para dieta com $16 \%$ de PB e R $\$ 0,36$ para a dieta com $14,5 \%$ de $\mathrm{PB}$.

Apesar de o custo/kg da dieta com $16 \%$ de PB com ureia como fonte nitrogenada principal ser semelhante à dieta com $14,5 \%$ de PB com ureia, o consumo de MS para a dieta com $16 \%$ foi maior $(43,91 \mathrm{~kg}$ vs. $42,23 \mathrm{~kg}$ ), o que elevou o custo diário por vaca. Apesar de maior consumo, não houve aumento da produção de leite com o aumento do 
teor proteico, tornando a margem total reduzida.

Em termos de preço bruto por quilo de produto, a ureia é $341,25 \%$ mais barata que o grão de soja ( $\mathrm{R} \$ 0,024 / \mathrm{kg}$ vs. R \$ 0,819/kg). Além de ser mais cara, a inclusão na dieta é mais alta $(120 \mathrm{~g} / \mathrm{kg}$ na dieta com teor proteico de $13 \%$ e $140 \mathrm{~g} / \mathrm{kg}$ na dieta com teor proteico de $14,5 \%$ ), elevando o preço da dieta total $(\mathrm{R} \$ 0,098 / \mathrm{kg}$ e $\mathrm{R} \$ 0,1146 / \mathrm{kg}$ de dieta total).

Além de ser a opção mais econômica de concentrado proteico, diversos estudos já relataram a eficiência da ureia na produção de leite. A adição de 1,5\% de ureia na MS de dieta completa, não alterou o consumo de MS e a qualidade e composição do leite (AQUINO et al., 2007). Em revisão realizada por Santos et al. (1998), alguns estudos com o uso de ureia como fonte proteica do concentrado mostraram efeitos negativos quando utilizada para vacas de alta produção e em início de lactação, quando as exigências de proteína metabolizável são elevadas (NRC, 2001).

Considerando o preço do quilo de proteína bruta da ureia em relação do farelo de soja ou de qualquer outro concentrado proteico de origem animal ou vegetal a relação será, por muito tempo ainda, favorável à ureia. Analisando-se os preços médios no ano de 2003 corrigidos para abril de 2004 pelo IGP-DI, do farelo de soja e da ureia, o custo da unidade de proteína bruta foi quatro vezes menor para a ureia (CEPEA, 2004; FNP, 2004). Tendo em vista que as dietas com farelo de soja foram as dietas com maior teor proteico (16\% e $15,7 \%)$, a eventual redução do teor proteico, com a menor inclusão da matéria prima na dieta poderia reduzir os custos, sem alterar a produtividade.

Figura 9 - Série histórica (2002-2012) dos preços médios mensais da cana de açúcar ao longo do ano

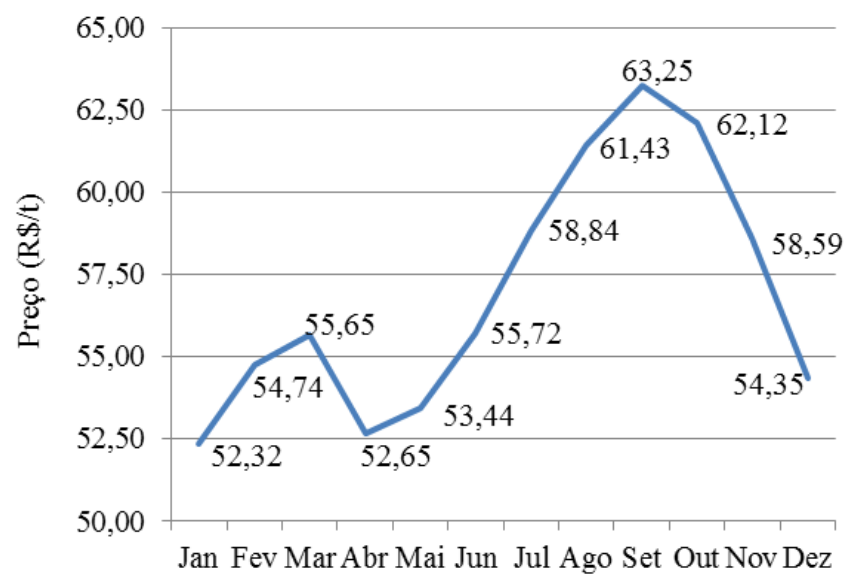

A dieta com menor margem total média foi a com 14,8\% de PB com grão de soja 
cru integral como fonte proteica, com valor de $-\mathrm{R} \$ 2,1569$. Sendo o mês de agosto com o menor prejuízo (-R \$1,2340) e dezembro e janeiro os de maiores prejuízos (-R \$3,2329 e $\mathrm{R} \$ 3,1732$ ). Ao longo do ano, o preço do grão de soja cru integral variou 13,48\% com valor mínimo de $\mathrm{R} \$ 0,77$ e valor máximo $\mathrm{R} \$ 0,89$ (Figura 10). Além de ser a dieta com maior custo, não gerou maior produção de leite, sendo a média de produção de 15,35 kg de leite/vaca, gerando um custo médio de $\mathrm{R} \$ 1,01 / \mathrm{kg}$ de leite.

Se o produtor para alimentar uma vaca com o concentrado a base de grão de soja gasta $\mathrm{R} \$ 15,68 /$ dia, e adotando que o custo da alimentação está em torno de $50 \%$ do custo total de produção do leite, essa vaca custaria $\mathrm{R} \$ 31,24$ por dia, e com o leite vendido a $\mathrm{R} \$$ 0,88, a produção diária deveria ser de 35,50 litros de leite apenas para pagar seu custo diário. Rebanhos com maior produtividade apresentam custo de dieta por animal mais elevado, mas a produção, também maior, costuma compensar o investimento. Quando se analisa o custo final da dieta por litro, vacas mais produtivas mostram-se mais rentáveis, visto que o custo por litro é menor (CEPEA, 2010).

Figura 10 - Série histórica (2002-2012) dos preços médios mensais do grão de soja cru integral ao longo do ano

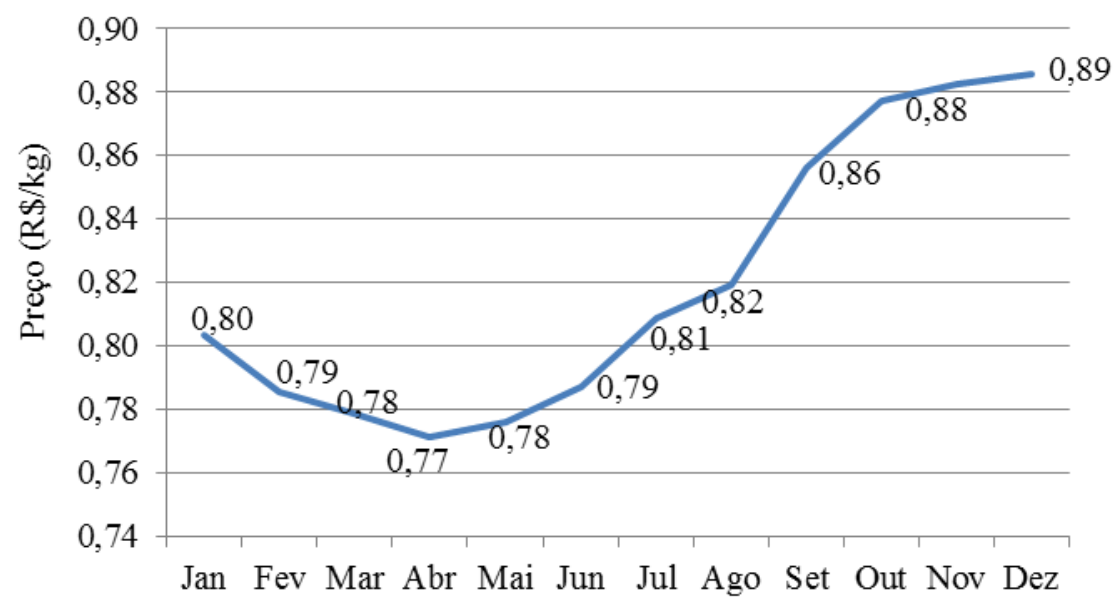

A maior vantagem do uso do grão de soja na dieta de vacas leiteiras é o aumento da densidade energética principalmente quando a energia é o nutriente limitante, geralmente no terço inicial de lactação. Nesse sentido, a dieta com 14,8\% de PB com grão de soja como fonte proteica, promoveu o aumento do teor de gordura do leite, com valor médio de 3,92\%. Se fosse considerado um programa de bonificação por teor de gordura no leite, o custo do litro seria então diluído, tornando a dieta mais barata para o produtor.

A utilização de subprodutos de indústrias pode ser boa alternativa de alimentos 
menos onerosos. O uso de do farelo de algodão, é bastante difundido pela sua composição nutricional e por conter proteína de boa qualidade. No presente estudo, a dieta com farelo de algodão a teor de $13 \%$ de PB quando analisado tanto da perspectiva de custo por quilo de dieta $(\mathrm{R} \$ 0,33)$ e por litro de leite produzido $(\mathrm{R} \$ 0,86)$, é competitiva com os demais ingredientes proteicos. Por outro lado, foi a dieta que direcionou para menor produção de leite (média de 17,17 kg/dia), desfavorecendo, portanto, a margem total por produção total de leite.

A bonificação por qualidade e teor de sólidos do leite é um cenário que já vem sendo implantado em algumas regiões e setores do país. Por exemplo, no Paraná, cerca de seis mil produtores estão recebendo pagamento diferenciado pelo teor de proteína do leite e contagem de células somáticas e contagem bacteriana total (AGÊNCIA DE NOTÍCIAS DO PARANÁ, 2013). Se considerarmos um pagamento diferenciado para o teor de proteína no leite, a dieta que oferece maior margem total continua sendo a com ureia no teor de $14,5 \%$ de $\mathrm{PB}$, porém, com um aumento de $22,3 \%$ passando de $\mathrm{R} \$ 1,85$ para $\mathrm{R} \$$ 2,39 (Figura 11).

Figura 11 - Margens totais das dietas em função dos preços pagos por teor de PB no leite

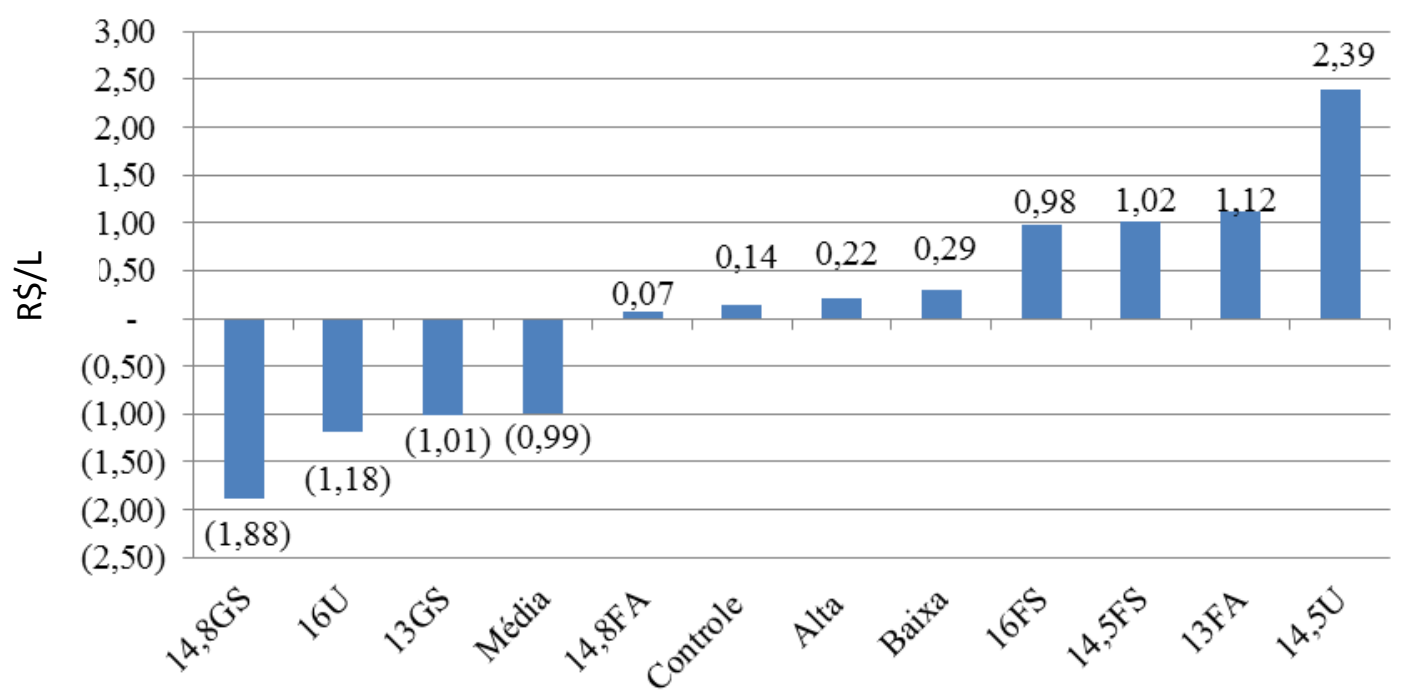

A dieta com farelo de algodão a $13 \%$ de PB foi a que apresentou menor custo por $\%$ de PB (Figura 12). No entanto, o teor de proteína do leite $(3,3 \%)$ ficou abaixo das demais dietas. A dieta com ureia a 14,5\% de PB resultou um teor de 3,34\% de proteína no leite. Com isso, apesar do menor custo de alimentação, a produtividade por litros e por teor de proteína bruta do leite não supera a remuneração que a dieta com 14,5\% de PB com ureia atinge. 
Figura 12- Curvas dos custos médios mensais das dietas por teor de proteína bruta no leite (20022012)

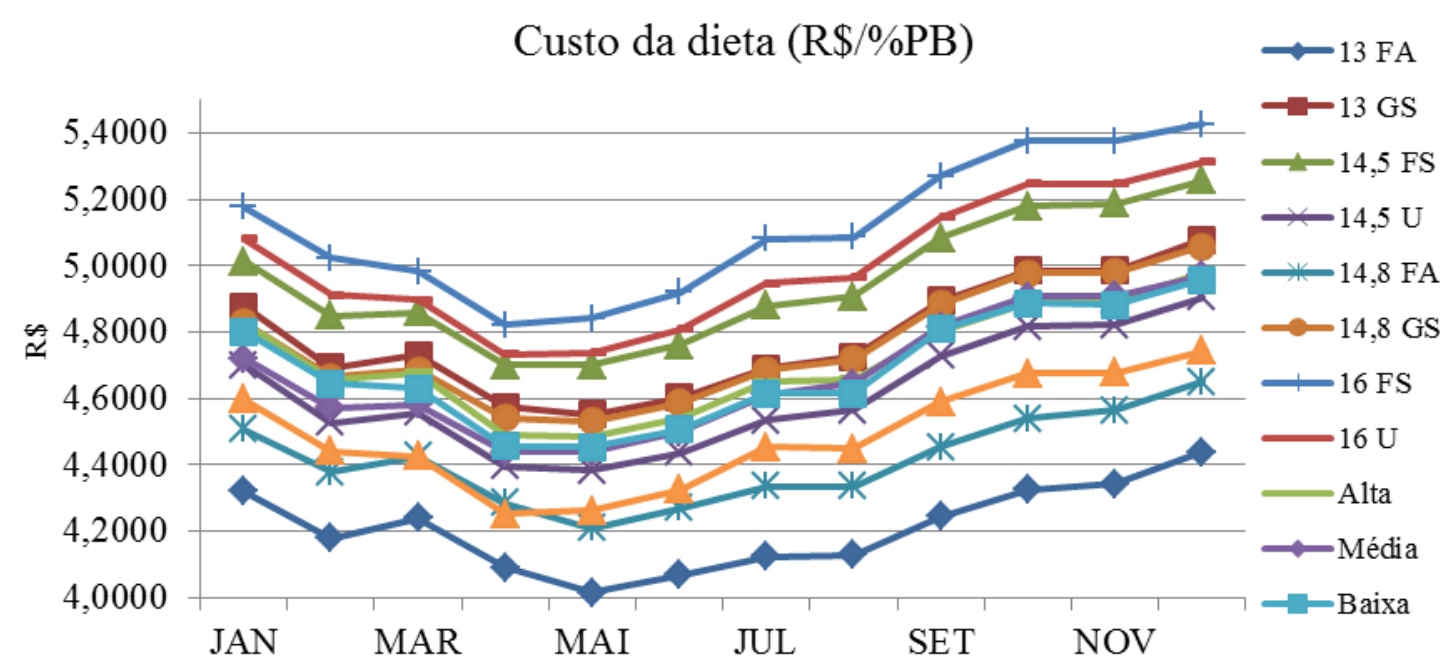

\subsection{CONCLUSÕES}

A dieta com teor proteico de $14,5 \%$ com ureia como fonte de nitrogênio principal apresentou-se a com maior eficiência econômica, com maior margem total, tanto no mercado convencional quanto no mercado com pagamento diferencial pela composição do leite. 


\section{REFERÊNCIAS}

AGÊNCIA DE NOTÍCIAS DO PARANÁ. Qualidade garante mais renda aos produtores do Programa Leite das Crianças. Governo do Estado do Paraná.

Disponível em:<http://www.aen.pr.gov.br/modules/noticias/article.php?storyid=76355>. Acesso em: 04 dez. 2013.

AFRC. AGRICULTURAL AND FOOD RESEARCH COUNCIL. Energy and protein requirements of ruminants. An advisory manual prepared by the AFRC Technical Committee on Responses to Nutrients. Wallingford, UK: CAB International, 1993. 159 p.

ALBRO, J. D.; WEBER, D. W.; DELCURTO, T. Comparison of whole, raw soybeans, extruded soybeans, or soybean meal and barley on digestive characteristics and performance of weaned beef steers consuming mature grass hay. Journal of Dairy Science, v. 71, p. 26-32, 1993.

ALDRICH, J. M.; MULLER, L. D.; VARGA, G. A.; GRIEL, L. C. Nonstructural carbohydrate and protein effects on rumen fermentation, nutrient flow, and performance of dairy cows. Journal of Dairy Science, v. 76, p. 1091-1100, 1993.

AQUINO, A. A.; BOTARO, B. G.; IKEDA, F. D.; RODRIGUES, P. H. M.; MARTINS, M. D.; DOS SANTOS, M. V. Effect of increasing dietary urea levels on milk yield and composition of lactating cows. Revista Brasileira de Zootecnia, v. 36, n. 4, p. 881-887, 2007.

AQUINO, A. A.; LIMA, Y. R.; BOTARO, B. G.; ALBERTO, C. S. S.; PEIXOTO, K. C.; SANTOS, M. V. Effects of dietary urea levels on milk protein fractions of Holstein cows. Animal Feed Science and Technology, v. 140, n. 1-2, p. 191-198, 2008.

BACH, A.; CALSAMIGLIA, S.; STERN, M. D. Nitrogen metabolism in the rumen. Journal of Dairy Science, v. 88, p. 9-21, 2005.

BACH, A.; HUNTINGTON, G. B.; CALSAMIGLIA, S.; STERN, M. D. Nitrogen metabolism of early lactation cows fed diets with two different levels of protein and different amino acid profiles. Journal of Dairy Science, v. 83, n. 11, p. 2585-2595, 2000.

BAKER, L. D.; FERGUSON, J. D.; CHALUPA, W. Responses in urea and true protein of milk to different protein feeding schemes for dairy cows. Journal of Dairy Science, v. 78, n. 11, p. 2424-2434, 1995.

BARBOSA SILVEIRA, I.D.. PETERS, M.D.P., STORCH, T., ZIGUER, E.A., FISCHER, V. Simulação da rentabilidade e viabilidade econômica de um modelo de produção de leite em free-stall. Arquivo Brasileiro de Medicina Veterinária e Zootecnia, v.63, n.2, p.392-398, 2011.

BARRAZA, M. L.; COPPOCK, C. E.; BROOKS, K.N., WILKS D.L., SAUDERS R.G. \& LATIMER JR G.W. Iron sulfate and feed pelleting to detoxify free gossypol in cottonseed diets for dairy cattle. Journal of Dairy Science. 74:3457-3467. 1991. 
BATEMAN II, H. G.; SPAIN, J. N.; KERLEY, M. S.; BELYEA, R. L.; MARSHALL, R. $\mathrm{T}$. Evaluation of ruminally protected methionine and lysine or blood meal and fish meal as protein sources for lactating Holsteins. Journal of Dairy Science, v. 82, n. 10, p. 2115-2120, 1999.

BERNARD, J. K. Effect of raw or roasted whole soybeans on digestibility of dietary nutrients and milk production of lactating dairy cows. Journal of Dairy Science, v. 73, n. 11, p. 3231- 3236, 1990.

BLACKWELDER, J. T.; HOPKINS, B. A.; DIAZ, D. E. Milk production and plasma gossypol of cows fed cottonseed and oilseed meals with our without rumen undegradable protein. Journal of Dairy Science, Albany, v. 81, p. 2934-2941, 1998.

BOERO, P. O.; BALCELLS, J.; MARTIN-ORUE, S. M.; LIANG, J. B.; GUADA, J. A. Excretion of purine derivatives in cows: endogenous contribution and recovery of exogenous purine bases. Livestock Production Science, v. 68, n. 2-3, p. 243-250, 2001.

BRODERICK, G. A. Effects of varying dietary protein and energy levels on the production of lactating dairy cows. Journal of Dairy Science, v. 86, n. 4, p. 1370-1381, 2003.

BRODERICK, G. A.; CLAYTON, M. K. A statistical evaluation of animal and nutritional factors influencing concentrations of milk urea nitrogen. Journal of Dairy Science, v. 80, n. 11, p. 2964-2971, 1997.

BRODERICK, G. A.; CRAIG, W. M.; RICKER, D. B. Urea versus true protein as supplement for lactating dairy-cows fed grain plus mixtures of alfalfa and corn silages. Journal of Dairy Science, v. 76, n. 8, p. 2266-2274, 1993.

BUTLER, W. R.; CALAMAN, J. J.; BEAM, S. W. Plasma and milk urea nitrogen in relation to pregnancy rate in lactating dairy cattle. Journal of Animal Science, v. 74, $\mathrm{n}$. 4, p. 858-865, 1996.

CALIXTO, M.; JOBIM, C. C.; DOS SANTOS, G. T.; BUMBIERIS, V. H. Blood constituents of holstein cows fed with corn or elephant-grass silages. Semina-Ciencias Agrarias, v. 31, n. 2, p. 429-437, 2010.

CAMPOS, O.F.; LIZIEIRE, R.S. Estratégias para obtenção de fêmeas de reposição em rebanhos leiteiros. In: PEIXOTO, A.M.; MOURA, J.C.; FARIA, V.P. (Eds.) Planejamento da exploração leiteira. Piracicaba: Fundação de Estudos Agrários Luiz de Queiroz, 1998. p.215-226.

CARVALHO, N. M.; MULHLBACH, P. R. F. Desempenho de vacas em lactação recebendo grãos de soja crus ou tostados, na composição da dieta. In: EUNIAO ANUAL DA SOCIEDADE BRASILEIRA DE ZOOTECNIA, 39., 2002 Anais... Recife. 2002. 5 p. CD-Rom.

CASTILLO, A. R.; KEBREAB, E.; BEEVER, D. E.; FRANCE, J. A review of efficiency of nitrogen utilisation in lactating dairy cows and its relationship with environmental pollution. Journal of Animal and Feed Sciences, v. 9, n. 1, p. 1-32, 2000. 
CEPEA. Esalq/USP. Receita compensa gasto extra com dieta para rebanhos mais produtivos. Boletim Técnico, v. 19, dez., 2007. Disponível em www.cepea.esalq.usp.br/leite. Acessado em: nov. 2013.

CHASE, L. E. Environmental considerations in developing dairy rations. In: CORNELL NUTRITION CONFERENCE FOR FEED MANUFACTURERS, 1994, Rochester, NY. Anais... [S.1]: Cornell University, 1994. 56-62 p.

CHEN, X. B.; GOMES, M. J. Estimation of microbial protein supply to sheep and cattle based on urinary excretion of purine derivatives - an overview of technical details.(Occasional publication). . In: INTERNATIONAL FEED RESEARCH UNIT, 1992, Aberdeen: Anais... [S.1]: Rowett Research Institute, 1992. 21 p.

CHEN, G.; RUSSELL, J. B. More monensin-sensitive, ammonia-producing bacteria from the rumen. Appl. Environ. Microbiol. v. 55, p. 1052-1057, 1989.

CHIOU, P. W. S.; YU, B.; WU, S. S. Effect of dietary protein source on performances and rumen characteristics of dairy cows. Animal Feed Science and Technology, v. 68, p. 339-351, 1997.

CHIZZOTTI, M. L.; VALADARES, S. C.; VALADARES, R. F. D.; CHIZZOTTI, F. H. M.; TEDESCHI, L. O.; MARCONDES, M. I.; FONSECA, M. A. Determination of creatinine excretion and evaluation of spot urine sampling to assess purine derivative excretion. Journal of Animal Science, v. 85, p. 63, 2007.

CHIZZOTTI, M. L.; VALADARES, S. D.; VALADARES, R. F. D.; CHIZZOTTI, F. H. M.; TEDESCHI, L. O. Determination of creatinine excretion and evaluation of spot urine sampling in Holstein cattle. Livestock Science, v. 113, n. 2-3, p. 218-225, 2008.

CLARK, J. H.; KLUSMEYER, T. H.; CAMERON, M. R. Microbial protein- synthesis and flows of nitrogen fractions to the duodenum of dairy-cows. Journal of Dairy Science, v. 75, n. 8, p. 2304-2323, 1992.

COLMENERO, J. J. O.; BRODERICK, G. A. Effect of amount and ruminal degradability of soybean meal protein on performance of lactating dairy cows. Journal of Dairy Science, v. 89, n. 5, p. 1635-1643, 2006.

COLUCCI, P. E.; CHASE, L. E.; VAN SOEST, P. J. Feed intake, apparent diet digestibility, and rate of particulate passage in dairy cattle. Journal of Dairy Science, $v$. 65, n. 8, p. 1445-1456, 1982.

COSTA, M.G.; CAMPOS, J.M.S.; VALADARES FILHO, S.C. Desempenho produtivo e vacas leiteiras alimentadas com diferentes proporções de cana-de-açúcar e concentrado ou silagem de milho na dieta. Revista Brasileira de Zootecnia, v.34, n.6, p.2437-2445, 2005 (supl.).

CONAB. Acompanhamento da safra Brasileira: cana-de-açúcar, safra 2012-2013, terceiro levantamento, setembro 2013. Brasília: Conab, 2013. 19 p. (Acompanhamento da safra Brasileira). 
CONTRERAS, P. A. Indicadores do metabolismo protéico utilizados nos perfis metabólicos de rebanhos. In: GONZÁLEZ, F. H. D. (Ed.). Book title. Porto Alegre: UFRGS, 2000. p.23-30

COOPER, J. M.; BIGGS, H. G. An evaluation of four methods of measuring urinary creatinine. Clinical chemistry, v. 7, p. 665-673, 1961.

CORDEIRO, C. F. D.; PEREIRA, M. L. A.; MENDONCA, S. D.; ALMEIDA, P. J. P.; AGUIAR, L. V.; DE FIGUEIREDO, M. P. Intake and total digestibility of nutrients and Milk production and composition in dairy cows fed with increasing crude protein levels in the diet with sugar cane and concentrates. Revista Brasileira de Zootecnia, v. 36, n. 6, p. 2118-2126, 2007.

COSTA, M. G. Cana-de-açúcar e concentrados em diferentes proporções para vacas leiteiras. 2004. 66 f. Dissertação (Mestrado em Zootecnia) - Universidade Federal de Viçosa, Viçosa, 2004. FNP (2004). Disponível em: <http://www.fnp.com.br>. Acesso em: dezembro de 2013.

COSTA, M. G.; CAMPOS, J. M. D.; VALADARES, S. D.; VALADARES, R. F. D.; MENDONCA, S. D.; SOUZA, D. D.; TEIXEIRA, M. D. Effects of feeding corn silage or different dietary ratios of sugarcane and concentrate on production of lactating dairy cows. Revista Brasileira de Zootecnia, v. 34, n. 6, p. 2437-2445, 2005.

CHEN, K. H.; HUBER, J. T.; THEURER, C. B. Effect of protein quality and evaporative cooling on lactational performance of Holstein cows in hot weather. Journal of Dairy Science, v. 76, p. 819-825. 1995.

DANKE, R. J.; PANCIERA, R. J.; TILIMAM, A. D. Gossipol toxicity studies with sheep. Journal of Animal Science, v. 24, p. 1199-1201, 1965.

DAVIDSON, S.; HOPKINS, B. A.; DIAZ, D. E. Effects of amount and degradability of dietary protein on lactation, nitrogen utilization and excretion in early lactation Holstein cows. Journal of Dairy Science, v.86, p. 1681-1689, 2003.

DERESZ, F.; FERNANDES, A. M.; MATOS, L. L. Utilização da soja-grão crua na alimentação de vacas leiteiras de alta produção. Revista Brasileira de Zootecnia, v. 25, n. 1, p. 113-124, 1996.

DIRKSEN, G.; BREITNER, W. A new quick-test for semiquantitative determination of betahydroxybutyric acid in bovine-milk. Journal of Veterinary Medicine Series aZentralblatt Fur Veterinarmedizin Reihe a-Physiology Pathology Clinical Medicine, v. 40, n. 9-10, p. 779-784, 1993.

FALDET, M. A.; SATTER, L. D. feeding heat-treated full fat soybeans to cows to early lactation. Journal of Dairy Science, v. 74, p. 3047-3054, 1991.

FATURI, C.; RESTLE, J.; PASCOAL, L.L. et al. Avaliação econômica de dietas com diferentes níveis de substituição do grão de sorgo por grão de aveia preta para terminação de novilhos em confinamento. Ciencia. Rural, v.33, p.937-942, 2003. 
FERNANDES, A. R. M.; SAMPAIO, A. A. M.; HENRIQUE, W.; TULLIO, R. R.; PERECIN, D.; OLIVEIRA, E. A. de; VILELA, H. L. F.; FAZOLO, B.; RIBEIRO, G. M.; SILVA, T. M. da. Eficiência produtiva e características qualitativas da carne de bovinos jovens terminados em confinamento -1. Consumo de nutrientes e desempenho. In: REUNIÃO ANUAL DA SOCIEDADE BRASILEIRA DE ZOOTECNIA, 43., 2006. Joao pessoa. Anais... Joao pessoa: SBZ, 2006. 1CD-ROM.

FERNANDES, A. M.; QUEIROZ, A. C.; LANA, R. P.; PEREIRA, J. C.; CABRAL, L. S.; VITTORI, A.; PEREIRA, E. S. Estimativas de produção de leite por vacas holandesas mestiças segundo o sistema CNCPS, em dietas contendo cana-de-açúcar com diferentes valores nutritivos. Revista Brasileira de Zootecnia, v. 30, n. 4, p. 1778-1785, 2003.

FRANK, B.; SWENSSON, C. Relationship between content of crude protein in rations for dairy cows and milk productions, concentration of urea in milk and ammonia emissions. Journal of Dairy Science, v. 85, p. 1829-1838, 2002.

FRASER, C. M. Manual merck de veterinária. 6. ed. São Paulo: Roca, 1991. 2169 p.

FUJIHARA, T.; ORSKOV, E. R.; REEDS, P. J.; KYLE, D. J. The effect of protein infusion on urinary-excretion of purine derivatives in ruminants nourished by intragastric nutrition. Journal of Agricultural Science, v. 109, p. 7-12, 1987.

GHORBANI, B.; GHOORCHI, T.; AMANLOU, H.; ZEREHDARAN, S. Effects of using monensin and different levels of crude protein on milk production, blood metabolites and digestion of dairy cows. Asian-Australasian Journal of Animal Sciences, v. 24, n. 1, p. 65- 72, 2011.

GIESECKE, D.; EHRENTREICH, L.; STANGASSINGER, M. Mammary and renal excretion of purine metabolites in relation to energy intake and milk yield in dairy cows. Journal of Dairy Science, v. 77, n. 8, p. 2376-2381, 1994.

GODDEN, S. M.; KELTON, D. F.; LISSEMORE, K. D.; WALTON, J. S.; LESLIE, K. E.; LUMSDEN, J. H. Milk urea testing as a tool to monitor reproductive performance in Ontario dairy herds. Journal of Dairy Science, v. 84, p. 1397-1406, 2001 b.

GOMES, A. L. Determinantes da queda do preço do leite recebido pelo produtor: uma abordagem de curto e longo prazo. 2002. 47 p. Dissertação (Mestrado) Universidade Federal de Viçosa, Viçosa - MG.

GOMES, S.T. Economia da ração na produção de leite. Jornal da Produção de Leite, v.13, n.143, p.1, 2001.

GOMES, S. T. Evolução e perspectivas da produção de leite no Brasil. In: GOMES A. T.; LEITE, J. L. B.; CARNEIRO A.V. (Ed). O Agronegócio do Leite no Brasil. Juiz de Fora: Embrapa Gado de Leite, 2001. p. 49-61.

GONDA, H. L.; LINDBERG, J. E. Effect of diet on Milk allantoin and its relationship with urinary allantoin in dairy cows. Journal of Dairy Science, v. 80, p. 364-373, 1997. 
GONZÁLEZ, F. H. D.; SCHEFFER, F. S. Perfil sangüíneo: ferramenta de análise clínica, metabólica e nutricional. In: SIMPÓSIO DE PATOLOGIA CLÍNICA DO RIO

GRANDE DO SUL, 1., 2003, Porto Alegre, RS. Anais... Porto Alegre, RS: Universidade Federal do Rio Grande do Sul, 2003. p.73-89.

GONZÁLEZ-RONQUILLO, M.; BALCELLS, J.; GUADA, J. A.; VICENTE, F. Purine derivative excretion in dairy cows: Endogenous excretion and the effect of exogenous nucleic acid supply. Journal of Dairy Science, v. 86, n. 4, p. 1282-1291, 2003.

GRINGS, E. E.;ROFFLER, R. E. DEITELHOFF, D. P. Response of dairy cows in early lactation to addition of cottonseed meal in alfalfa-based diets. Journal Dairy Science, $v$. 74, p. 2580-2587, 1991.

GUIMARÃES JUNIOR, R.; PEREIRA, L. G. R.; TOMICH, T. R.; GONÇALVES, L. C.; FERNANDES, F. D.; BARIONI, L. G.; MARTHA JÚNIOR, G. B. Ureia na alimentação de vacas leiteiras. [S.1]: Embrapa Cerrados, 2007.

GUSTAFSSON, A. H.; PALMQUIST, D. L. Diurnal-variation of rumen ammonia, serum urea, and milk urea in dairy-cows at high and low yields. Journal of Dairy Science, v. 76, n. 2, p. 475-484, 1993.

HRISTOV, A. N.; ETTER, R. P.; ROPP, J. K.; GRANDEEN, K. L. Effect of dietary crude protein level and degradability on ruminal fermentation and nitrogen utilization in lactating dairy cows. Journal of Animal Science, v. 82, n. 11, p. 3219-3229, 2004.

HOOVER, W. H.; STOKES, S. R. Balancing carbohydrates and proteins for optimum rúmen microbial yield. Journal of Dairy Science, v. 74, n. 10, p. 3630-3644, 1991.

INSTITUTO ADOLFO LUTZ (São Paulo). Normas Analíticas do Instituto Adolfo Lutz. Métodos químicos e físicos para análise de alimentos. 3 ed. São Paulo: Instituto Adolfo Lutz, 1985. v. 1.

INSTITUTO BRASILEIRO DE GEOGRAFIA E ESTATISTISCA (IBGE). Censo Agropecuário 1995/96 . Disponível em < $\underline{w w w . i b g e . g o v . b r}>$ Acesso em 26 de Dezembro de 2013.

IBGE. INSTITUTO BRASILEIRO DE GEOGRAFIA E ESTATÍSTICA. Diretoria de Pesquisas, Coordenacao de Agropecuaria. Pesquisa Trimestral do Leite, 1997-2012. Brasília: IBGE, 2013. Se for site indicar o endereço do site por ex. Disponível em: < http://www.ibge.gov.br/home/estatistica/pesquisas/pesquisa_resultados.php?id_pesquisa= 43>. Acesso em: 30 de Outubro de 2013.

INRA. INSTITUT NATIONAL DE LA RECHERCHE AGRONOMIQUE. JARRIGE, E. (Ed.). Ruminant nutrition. London: INRA; John Libbey Ed., 1988. 471 p.

JESUS, E. F.; CONTI, L. H. A.; TOMAZI, T.; MIGLIANO, M. E. D. A.; SILVA, L. F. P.; RENNÓ, F. P.; SANTOS, M. V. Intake, nutrient digestibility and milk yield of dairy cows fed urea and two levels of crude protein in diets with sugar cane. Journal of Animal and Veterinary Advances, v. 11, p. 4135-4142, 2012. 
JONKER, J. S.; KOHN, R. A.; ERDMAN, R. A. Using milk urea nitrogen to predict nitrogen excretion and utilization efficiency in lactating dairy cows. Journal of Dairy Science, v. 81, n. 10, p. 2681-2692, 1998.

KALSCHEUR, K. F.; BALDWIN, R. L.; GLENN, B. P.; KOHN, R. A. Milk production of dairy cows fed differing concentrations of rumen-degraded protein. Journal of Dairy Science, v. 89, n. 1, p. 249-259, 2006.

KEBREAB, E.; FRANCE, J.; BEEVER, D. E.; CASTILLO, A. R. Nitrogen pollution by dairy cows and its mitigation. Nutrient Cycling in Agroecosystems, v. 60, p. 275-285, 2001 .

KUNG JR., L.; STANLEY, R. W. Effect of stage of maturity on the nutritive value of whole-plant sugarcane preserved as silage. Journal of Animal Science, v. 54, p. 689696, 1982.

LANA, R. P. Efficiency of use of concentrate ration on weight gain and milk production by cattle under tropical pasture and intensive conditions in Brazil. Journal of Animal Science, v. 82, p. 222, 2004. Supplement, 1.

LENG, R. A.; NOLAN, J. V. Nitrogen metabolism in the rumen Journal of Dairy Science, v. 67, p. 1072-1089, 1984.

LENG, R. A.; PRESTON, T. R. Sugar cane for cattle production: Present constraints, perspectives and research priorities. Trop. Ani. Prod.título da revista por extenso, v. 1, p. $1-22,1976$.

LEONARDI, C.; STEVENSON, M.; ARMENTANO, L. E. Effect of two levels of crude protein and methionine supplementation on performance of dairy cows. Journal of Dairy Science, v. 86, n. 12, p. 4033-4042, 2003.

LIENER, I. E. Implications of antinutritional components in soybean foods. Crit. Rev. Food Sci. Nutr. título da revista por extensor, v. 34, p. 31-67, 1994.

LOPES, M.A.; CARVALHO, F.M. Custo de produção do leite. Boletim Agropecuário, n.32, 2000. 42 p.

LYNCH, J. M.; BARBANO, D. M.; FLEMING, J. R. Indirect and direct determination of the casein content of milk by Kjeldahl nitrogen analysis: Collaborative study. Journal of Aoac International, v. 81, n. 4, p. 763-774, 1998.

MACEDO, M. A. S.; STEFFANELLO, M., OLIVEIRA, C. A. Eficiência combinada dos fatores de produção: aplicação de Análise Envoltória de Dados (DEA) à produção leiteira. Disponível em www.custoseagronegocioonline.com.br. V. 3, n,2 - Jul/Dez 2007. Acessado em 27 de Dezembro de 2013.

MAGALHAES, A. L. R.; CAMPOS, J. M. D.; VALADARES, S. D.; TORRES, R. D.; NETO, J. M.; DE ASSIS, A. J. Sugar cane as a substitute for corn silage in diets for milking cows. performance and economical viability. Revista Brasileira de Zootecnia, v. 33, n. 5, p. 1292-1302, 2004. 
MAGALHÃES, A. L. R.; CAMPOS, J. M. S.; VALADARES FILHO, S. C.; descrever os demais autores Cana de açúcar em substituição à silagem de milho em dietas para vacas em lactação: parâmetros digestivos e ruminais. Revista Brasileira Zootecnia, v. 35, n. 2, p. 591-599, 2006.

MARTINEZ, J. S. Avaliação de co-produtos na alimentação de vacas leiteiras mantidas em pastagens tropicais durante a estação chuvosa e alimentadas no cocho durante a estação de seca. 2008. 351 p. Tese (Doutorado em Agronomia) - Escola Superior de Agricultura Luiz de Queiroz, Piracicaba, 2008.

MARTINS, P. C. Análise comparativa entre os sistemas de produção de leite da EMBRAPA e sistemas de produção em fazendas do Estado de Minas Gerais. Viçosa, 1988. 108p. Dissertação (M.S.) -Universidade Federal de Viçosa.

MARTINS, P. C. Políticas públicas e mercados deprimem o resultado do sistema agroindustrial do leite. 2002. 217 p. Tese (Doutorado) - Escola Superior de Agricultura "Luiz de Queiroz", Universidade de São Paulo, Piracicaba - SP.

McDONALD, P. M.; EDWARDS, R. A.; GREENHALGH, J. F. D.; MORGAN, C. A. Animal nutrition. Harlow, UK: Pearson, 2002. 693 p.

MENA, H.; SANTOS, J. E. P.; HUBER, J. T.; SIMAS, J. M.; TARAZON, M.;

CALHOUN, M. C. The effects of feeding varying amounts of gossypol from whole cottonseed and cottonseed meal in lactating dairy cows. Journal of Dairy Science, v. 84, p. 2231-2239, 2001.

MIELKE, C. D.; SHINGOETHE, D. J. Heat-treated soybeans for lactating cows. Journal of Dairy Science, v. 64, p. 1579, 1981.

MORA, P. J. G.; LEÃO, M. I.; VALADARES FILHO, S. C. Grão de soja em rações para vacas lactantes: consumo dos nutrientes, produção e composição do leite. Revista Brasileira de Zootecnia, v. 25, n. 2, p. 369-381, 1996.

MOREIRA, A. L.; PEREIRA, O. G.; GARCIA, R. Produção de leite, consumo e digestibilidade aparente dos nutrientes, $\mathrm{pH}$ e concentração de amônia ruminal em vacas lactantes recebendo rações contendo silagem de milho e fenos de alfafa e de capim coastcross. Revista Brasileira de Zootecnia, v. 30, n. 3, p. 1089-1098, 2001. Suplemento.

MOSCARDINI, S.; WRIGHT, T. C.; LUIMES, P. H.; MCBRIDE, B. W.; SUSMEL, P. Effects of rumen-undegradable protein and feed intake on purine derivative and urea nitrogen: Comparison with predictions from the Cornell net carbohydrate and protein system. Journal of Dairy Science, v. 81, n. 9, p. 2421-2429, 1998.

MUCK, R. E. Urease activity in bovine feces. Journal of Dairy Science, v. 65, n. 11, p. 2157-2163, 1982. 
NOUSIAINEN, J.; SHINGFIELD, K. J.; HUHTANEN, P. Evaluation of milk urea nitrogen as a diagnostic of protein feeding. Journal of Dairy Science, v. 87, n. 2, p. 386398, 2004.

NAVES, J. R. Utilização de fontes nitrogenadas com diferentes taxas de degradabilidade em dietas a base de cana de açúcar para vacas leteiras. 2010. falta total de páginas. Dissertação (Mestrado em Nutrição e Produção Animal) - Faculdade de Medicina Veterinária e Zootecnia - VNP, Universidade de São Paulo, Pirassununga, 2010.

NOCEK, J. E. In situ and other methods to estimate ruminal protein and energy digestibility. A review. Journal of Dairy Science, v. 71, p. 2051-2069, 1988.

NOFTSGER, S. M.; HOPKINS, B. A.; DIAZ, D. E. Effect of whole and expanded expelled cottonseed on milk yield and blood gossypol. Journal of Dairy Science, v. 83, p. 2539-2547, 2000.

NRC. NUTRIEN REQUERIMENT OF BEEF CATTLE. Washington: National Academy Press 1996. v. 7, 242 p.

NRC. NUTRIENT REQUIREMENTS OF DAIRY CATTLE. Washington, D.C.: National Academy Press 1989. 158 p.

NRC. NUTRIENT REQUIREMENTS OF DAIRY CATTLE. Washington: National Academy Press, 2001. v. 7. 381 p.

NUSSIO, L. G.; SCHIMIDT, P. Alternativas no uso da cana-de-açúcar na alimentação de bovinos. In: SIMPÓSIO GOIANO SOBRE MANEJO E NUTRIÇÃO DE BOVINOS DE CORTE E LEITE, 7., 2005, Goiânia, GO. Anais... Goiânia: CBNA, 2005. p. 299-323.

OLIVEIRA, A. S. Casa de café ou casa de soja em substituição ao milho em dietas à base de cana-deaçúcar para vacas leiteiras. 2005. 97 f. Dissertação (Mestrado em Zootecnia) - Universidade Federal de Viçosa, Viçosa, 2005.

OLIVEIRA, T.B.A.; FIGUEIREDO, R.S.; OLIVEIRA, M.W.; NASCIF, C. Índices e rentabilidade da pecuária leiteira. Scientia Agrícola, v. 58, n.4, p. 687-692, 2001

OLIVEIRA, A. S.; VALADARES, R. F. D.; VALADARES FILHO, S. V.; CECON, P. R.; OLIVEIRA, G. A.; SILVA, R. M. N.; COSTA, M. A. L. Intake, Apparent Digestibility, Milk Composition and Production of Lactating Cows Fed Four non Protein Nitrogen Compounds Levels. Revista Brasileira de Zootecnia, v. 30, n. 4, p. 1358-1366, 2001a.

OLIVEIRA, A. S.; VALADARES, R. F. D.; VALADARES, S. D.; CECON, P. R.; RENNO, L. N.; DE QUEIROZ, A. C.; CHIZZOTTI, M. L. Microbial protein production, purine derivatives and urea excretion estimate in lactating dairy cows fed isoprotein diets with different non protein nitrogen compounds levels. Revista Brasileira de Zootecnia, v. 30, n. 5, p. 1621-1629, 2001 b. 
OLIVEIRA, J. C. M.; TIMM, L. C.; TOMINAGA, T. T.; CASSARO, F. A. M.; REICHARDT, K.; BACCHI, O. O. S.; DOURADO-NETO, D.; CAMARA, G. M. D. Soil temperature in a sugar-cane crop as a function of the management system. Plant and Soil, v. 230, n. 1, p. 61-66, 2001.

ONODERA, R. Ureolytic activity of the washed cell suspension of rumen ciliate protozoa. Agricultural Biology Chemestry título, Bunkyo-Ku, v. 41, p. 2177-82, 1977.

ORSKOV, E. R.; McDONALD, P. The estimation of protein degradability in the rumen from incubation measurements weighted according to rate of passage. Journal of Agricultural Science, v. 92, p. 499-503, 1979.

ØRSKOV, E. R.; MILLER, E. L. Protein evaluation in ruminants. Netherlands: Elsevier: B.V., 1988. p. 103-127. (Feed Science).

PAYNE, J. M.; PAYNE, S. The metabolic profile test. Equine Veterinary Journal, v. 20, n. 6, p. 1-179, 1987. .

PEDROSO, A. D.; NUSSIO, L. G.; RODRIGUES, A. D.; SANTOS, F. A. P.; MOURAO, G. B.; BARIONI, W. Performance of dairy cows fed rations produced with sugarcane silages treated with additives or fresh sugarcane. Revista Brasileira de Zootecnia, v. 39, n. 9, p. 1889-1893, 2010.

PEREIRA, E. S.; QUEIROZ, A. C.; PAULINO, M. F. descrever os demais autores Determinação das frações proteicas e de carboidratos e taxas de degradação in vitro da cana-de-açúcar, da cama de frango e do farelo de algodão. Revista Brasileira de Zootecnia, v. 29, n. 6, p. 1887-1893, 2000.

PEREIRA, J. C.; CUNHA, D. N. F. V.; CECON, P. R.; FARIA, E. S. Comportamento Ingestivo e taxa de passagem de partículas em novilhas leiteiras de diferentes grupos genéticos submetidas a dietas com diferentes níveis de fibra. Revista Brasileira de Zootecnia, v. 36, p. 2134-2142, 2007.

PIRES, A. V.; SUSIN, I. M.; SIMAS, J. M. C.; OLIVEIRA JUNIOR, R. C.; FERNANDES, J.J. R.; ARAUJO, R. C.; MENDES, C. Q. Substituição de silagem de milho por cana-de-açúcar e caroço de algodão sobre o desempenho de vacas holandesas em lactação. Ciência Animal Brasileira, v. 11, n. 2, p. 251-257, 2010.

PRESTON, T. R. Nutritional limitations associated with the feeding of tropical forages. Journal of Animal Science, v. 54, n. 4, p. 877-884, 1982.

PRESTON, T. R.; LENG, R. A. Sugar-cane as cattle feed. World Animal Review, n. 27, p. 7-12, 1978.

PRIETO, J. G.; DEPETERS, E. J.; ROBINSON, P. H. Increasing dietary levels of cracked Pima cottonseed increase plasma gossypol but do not influence productive performance of lactating Holstein cows. Journal of Dairy Science, v. 86, p. 254-267, 2003. 
RANGEL, A. H. N., CAMPOS, J. M. S., BRITO, A. F., BRAGA, A. P., LIMA, R. N. Análise econômica da alimentação de vacas leiteiras com cana de açúcar corrigida com farelo de soja e ureia. Revista Caatinga (Mossoró, Brasil) v.21, n.2, p.73-75. 2008

REIS, R.; MEDEIROS, A.; MONTEIRO, L. Custos de produção da atividade leiteira na região sul de Minas Gerais. Organizações Rurais \& Agroindustriais, América do

Norte, 2011. Disponível em: http://revista.dae.ufla.br/index.php/ora/article/view/272/268. Acesso em: 30 nov. 2013.

RENNO, L. N.; VALADARES, S. D.; PAULINO, M. F.; LEAO, M. I.; VALADARES, R. F. D.; RENNO, F. P.; PAIXAO, M. L. Urea levels in diet for steers of four genetic groups: ruminal parameters, plasma urea, urea and creatinine excretions. Revista Brasileira de Zootecnia-Brazilian Journal of Animal Science, v. 37, n. 3, p. 556-562, 2008.

RENNÓ, L. N.; VALADARES, R. F. D.; LEÃO, M. I.; VALADARES FILHO, S. C.; SILVA, J. F. C.; CECON, P. R.; DIAS, H. L. C.; COSTA, M. A. L.; OLIVEIRA, R. V. Estimativa da produção de proteína microbiana pelos derivados de purina na urina em novilhos. Revista Brasileira de Zootecnia, v. 29, n. 4, p. 1223-1234, 2000.

ROSELER, D. K.; FERGUSON, J. D.; SNIFFEN, C. J.; HERREMA, J. Dietary-protein degradability effects on plasma and milk urea nitrogen and milk nonprotein nitrogen in holstein cows. Journal of Dairy Science, v. 76, n. 2, p. 525-534, 1993.

RUSSELL, J. B.; OCONNOR, J. D.; FOX, D. G.; VANSOEST, P. J.; SNIFFEN, C. J. A net carbohydrate and protein system for evaluating cattle diets.1. Ruminal fermentation. Journal of Animal Science, v. 70, n. 11, p. 3551-3561, 1992.

RUSSEL, J. B.; RYCHLIK, J. L. Factors that alter rumen microbial ecology. Science, v.292, p.1119-1122, 2001.

SAMPAIO, A. A. M.; OLIVEIRA, M. S.; TOSI, H. descrever os demais autores Utilização da soja grão e do farelo de soja na terminação de bovinos castrados e inteiros em confinamento. In: REUNIÃO ANUAL DA SOCIEDADE BRASILEIRA DE ZOOTECNIA, 37., 1995, Brasília. Anais... Brasília: Sociedade Brasileira de Zootecnia, 1995. p. 301-303.

SANCHEZ, J. M.;CLAYPOOL, D. W. Canola meal as a protein supplement in dairy rations. Journal of Dairy Science, v. 66, p. 80-85, 1983.

SANTOS, F. A. P. Metabolismo de proteínas. In: BERCHIELI, T. T.; PIRES, A. V. descrever os demais autores (Ed.). Book title. Jaboticabal: Funep, 2006. p.583

SANTOS, F. A. P. descrever os demais autores Effects of rumen-undegradable protein on dairy cow performance: A 12-year literature review. Journal of Dairy Science, v. 81, p. 3182-3213, 1998. 
SANTOS, J. E. P.; VILLASEÑOR, M.; ROBINSON, P. H. Type of cottonseed and level of gossypol in diets of lactating dairy cows: Plasma gossypol, health and reproductive performance. Journal of Dairy Science, v. 86, p. 892-905, 2003 a.

SANTOS, G. T.; ZAMBOM, M. A.; ALCALDE, C. R.; MODESTO, E. C.; GONÇALVES, G. D.; FAUSTINO, J. O.; SILVA, K. T.; RAMOS, C. E. C. O. Degradabilidade in situ da matéria seca, matéria orgânica e energia bruta da casca do grão de soja moída ou peletizada. In: REUNIÃO ANUAL DA SOCIEDADE BRASILEIRA DE ZOOTECNIA, 39., 2002, Recife. Anais... Recife: Sociedade Brasileira de Zootecnia, 2002.

SCHIFFLER, E. A. Análise de eficiência técnica e econômica de sistemas de produção de leite na Região de São Carlos, São Paulo, 1998. 128p. Dissertação (M.S.) -Universidade Federal de Viçosa.

SCHIMIDT, P.; NUSSIO, L.G. Produção e utilização de cana de açúcar para bovinos leiteiros: novas demandas. Anais... Bovinocultura de Leite: Nutrição, Reprodução e Fertilidade em Bovinos, 2005.

SOUZA, D. P. H. de Avaliação de Métodos Paramétricos e não paramétricos na análise da eficiência da produção de leite. 2003. 147 p. Tese (Doutorado) - Escola Superior de Agricultura "Luiz de Queiroz", Universidade de São Paulo, Piracicaba - SP.

SOUZA, D. P.; CAMPOS, J. M. S.; LANA, R. P.; SEDYAMA, C. A. Z.; NETO, J. M. Comportamento ingestivo, consumo e digestibilidade de nutrientes, produção e composição do leite de vacas alimentadas com silagem de milho ou cana-de-açúcar com caroço de algodão. Revista Brasileira de Zootecnia, v. 38, n. 10, p. 2053-2062, 2009.

SANTOS, F. A. P. Metabolismo de proteínas. In: BERCHIELI, T. T.; PIRES, A. V. descrever os demais autores (Ed.). Book title. Jaboticabal: Funep, 2006. p.583

SCHEPERS, A. J.; MEIJER, R. G. M. Evaluation of the utilization of dietary nitrogen by dairy cows based on urea concentration in milk. Journal of Dairy Science, v. 81, n. 2, p. 579- 584, 1998.

SCHWINGEL, W. R.;BATES, D. B. Use of sodium dodecyl sulfate polyacrylamide gel electrophoresis to measure degradation of soluble soybean proteins by Prevotella ruminicola GA33 or mixed urinal microbes in vitro. Journal of Animal Science, v. 74, p. 475-482, 1996.

SHABI, Z.; TAGARI, H. ;MURPHY, M.; BRUCKENTAL, I.; MABJEESH, S.; ZAMWEL, S.; CELIK, K.; ARIELI. A.; TAGARI, H. Partitioning of Amino Acids Flowing to the Abomasuminto Feed, Bacterial, Protozoal, and Endogenous Fractions. Journal of Dairy Science, v. 83, p. 2326-2334, 2000.

SILVA, D. J.; QUEIROZ, A. C. Análise de alimentos (métodos químicos e biológicos). Viçosa: UFV, Impr. Univ, 2002. 235 p.

SOUSA, D. D.; CAMPOS, J. M. D.; VALADARES, S. D.; LANA, R. D.; SEDIYAMA, C. A. Z.; NETO, J. M. Feeding behavior, feed intake and digestibility, milk composition 
and production of cows fed maize silage or sugarcane with whole cottonseed. Revista Brasileira de Zootecnia, v. 38, n. 10, p. 2053-2062, 2009.

STANGASSINGER, M.; CHEN, X. B.; LINDBERG, J. E.; GIESECKE, D. Metabolism of purines in relation to microbial production. In: Ruminant physiology: digestion, metabolism, growth and reproduction. Stuttgart, Germany: Ferdinand Enke Verlag, 1995. p. 387-406.

STERN, M. D.; HOOVER, W. H. Methods for determining and factors affecting rumen microbial protein synthesis: a review. Journal of Animal Science, v. 49, n. 6, p. 15901603. 1979.

STORM, E.; ORSKOV, E. R. The nutritive value of rumen micro-organisms in ruminants. 1. Large-scale isolation and chemical composition of rumen micro-organisms. The British Journal of Nutrition, v. 50, n. 2, p. 463-70, 1983.

TAMMINGA, S. Nutrition management of dairy cows as a contribution to pollution control. Journal of Dairy Science, v. 75, p. 345-357, 1992.

TAMMINGA, S. Protein degradation in the forestomachs of ruminants. Journal of Dairy Science, v. 49, p. 1615-1630, 1979.

TAN WILSON, A. L.; WILSON, K. A. Relevance of multiple soybean trypsin inhibitor forms to nutritional quality. Adv Exp Med Biolo título da revista por extenso, v. 199, p. 391-411, 1986

TORRES, R. A.; REZENDE, H. Os fundamentos da cultura da cana. Leite B, São Paulo, v. 11, n. 119, p.406-409, 1996. (Caderno de Tecnologia n. 51).

VAGNONI, D. B.; BRODERICK, G. A. Effects of supplementation of energy or ruminally undegraded protein to lactating cows fed alfafa hay or silage. Journal of Dairy Science, v. 80, p. 8, p. 1703-1712, 1997.

VALADARES, R. F. D.; BRODERICK, G. A.; FILHO, S. C. V.; CLAYTON, M. K. Effect of replacing alfalfa silage with high moisture corn on ruminal protein synthesis estimated from excretion of total purine derivatives. Journal of Dairy Science, v. 82, n. 12, p. 2686- 2696, 1999a.

VALADARES, R. F. D.; BRODERICK, G. A.; VALADARES, S. C.; CLAYTON, M. K. Effect of replacing alfalfa silage with high moisture corn on ruminal protein synthesis estimated from excretion of total purine derivatives. Journal of Dairy Science, v. 82, n. 12, p. 2686-2696, 1999 b.

VALADARES, R. F. D.; GONÇALVES, L. C.; SAMPAIO, I. B. Níveis de proteína em dietas de bovinos. 4. Concentrações de uréia plasmática e excreções de uréia e creatinina. Revista Brasileira de Zootecnia, v. 26, n. 6, p. 1270-1278, 1997.

VAN HORN, H. H.; NEWTON, G. L.; NORDSTEDT, R. A.; FRENCH, E. C.; KIDDER, G.; GRAETZ, D. A.; CHAMBLISS, C. F. Dairy manure management: 
strategies for recycling nutrients to recover fertilizer value and avoid environmental pollution. Grainenville, FL: Florida Coop Extension Services, 1996. 24 p.

VAN SOEST, P. J. Nutritional ecology of the ruminants. Ithaca, NY: Cornell Univerisity Press, 1994. 476 p.

VANHORN, H. H.; WILKIE, A. C.; POWERS, W. J.; NORDSTEDT, R. A. Components of dairy manure management-systems. Journal of Dairy Science, v. 77, n. 7, p. 20082030, 1994.

VANSOEST, P. J.; MASON, V. C. The influence of the maillard reaction upon the nutritivevalue of fibrous feeds. Animal Feed Science and Technology, v. 32, n. 1-3, p. 45-53, 1991.

VASCONCELOS, A. M.; LEÃO, M. I.; VALADARES FILHO, S. C.; VALADARES, R. F. D.; DIAS, M.; MORAIS, D. A. E. F. Parâmetros ruminais, balanço de compostos nitrogenados e produção microbiana de vacas leiteiras alimentadas com soja e seus subprodutos. Revista Brasileira de Zootecnia, v. 39, n. 2, p. 425-433, 2010.

VILELA, D. Cadeia produtiva de bovinos de leite e estratégias para produção sustentável. In: REUNIÃO ANUAL DA SOCIEDADE BRASILEIRA DE ZOOTECNIA, 41., 2004, Campo Grande. A produção animal e a segurança alimentar. Anais... Campo Grande: SBZ, 2004. p. 1-18.

VILELA, F. G.; TEIXEIRA, J. C.; PEREZ, J. R. O.; PAIVA, P. C. D.; MUNIZ, J. A.; REIS, S. T. Effect of the substitution of the soybean meal for the starea $150 \mathrm{~S}$ in the intake, production and composition of the milk. Ciencia E Agrotecnologia, v. 31, n. 5, p. 1512- 1518, 2007.

VOLTOLINI, T. V.; SANTOS, F. A. P.; MARTINEZ, J. C.; BITTAR, C. M. M.; IMAIZUMI, H.; CORTINHAS, C. S. Diferentes teores de proteína metabolizável em rações com cana-de-açúcar para vacas em lactação. Ciência Animal Brasileira, v. 9, n. 2, p. 309- 318, 2008.

WANG, C.; LUI, J. X.; YUAN, Z. P.; WU, Y. M.; ZHAI, S. W.; YE, H. W. Effect of level of metabolizable protein on milk production and nitrogen utilization in lactating dairy cows. Journal of Dairy Science, v. 90, n. 6, p. 2960, 2007.

WATTIAUX, M. A.; KARG, K. L. Protein level for alfalfa and corn silage-based diets: II. Nitrogen balance and manure characteristics. Journal of Dairy Science, v. 87, p. 3492-3502, 2004.

WEISS, W. P.; CONRAD, H. R.; PIERRE, N. R. S. T. A theoretically-based model for predicting total digestible nutrient values of forages and concentrates. Animal Feed Science Technology, v. 39, p. 95-110, 1992.

WITHERS, L. A.; WILLIAMS, J. T. Conservação in vitro de recursos genéticos de plantas. In: TORRES, A. C.; CALDAS, L. S.; BUSO, J. A. (Ed.). Cultura de tecidos e transformação genética de plantas. Brasília: Embrapa-SPI, 1998. p. 297-330 
YAN, T.; FROST, J. P.; AGNEW, R. E.; BINNIE, R. C.; MAYNE, C. S. Relationships among manure nitrogen output and dietary and animal factors in lactating dairy cows. Journal of Dairy Science, v. 89, n. 10, p. 3981-3991, 2006. 